UNIVERSIDADE DE SÃO PAULO

FACULDADE DE FILOSOFIA, LETRAS E CIÊNCIAS HUMANAS

DEPARTAMENTO DE TEORIA LITERÁRIA E LITERATURA COMPARADA

EZIEL BELAPARTE PERCINO

\title{
DELEUZE COM PROUST
}


EZIEL BELAPARTE PERCINO

\section{DeleuZe CoM Proust}

Tese apresentada ao Programa de Pós-Graduação em Teoria Literária e Literatura Comparada da Faculdade de Filosofia, Letras e Ciências Humanas da Universidade de São Paulo para a obtenção do título de Doutor em Teoria Literária e Literatura Comparada

Orientadora: Profa. Dra. Regina Lúcia Pontieri 
Autorizo a reprodução e a divulgação deste trabalho, por qualquer meio convencional ou eletrônico, para fins de estudo e pesquisa, desde que citada a fonte.

Catalogação da Publicação

Serviço de Biblioteca e Documentação

Faculdade de Filosofia, Letras e Ciências Humanas

Universidade de São Paulo

Percino, Eziel Belaparte

Deleuze com Proust / Eziel Belaparte Percino; Orientadora: Regina Lúcia Pontieri - São Paulo, 2017.

138 f.: il.

Tese (Doutorado) - Faculdade de Filosofia, Letras e Ciências Humanas da Universidade de São Paulo. Departamento de Teoria Literária e Literatura Comparada.

Área de concentração: Teoria Literária e Literatura Comparada

1. Gilles Deleuze. 2. Marcel Proust. 3. Filosofia. 4. Teoria Literária. 
Nome: Eziel Belaparte Percino

Título: Deleuze com Proust

Tese apresentada ao Programa de Pós-Graduação em Teoria Literária e Literatura Comparada da Faculdade de Filosofia, Letras e Ciências Humanas da Universidade de São Paulo para a obtenção do título de Doutor em Teoria Literária e Literatura Comparada.

Área de concentração: Teoria Literária e Literatura Comparada

Banca Examinadora

Profa. Dra. Regina Lúcia Pontieri (orientadora) - USP

Prof. Dr. Marcos Piason Natali - USP

Profa. Dra. Júlia Maria Costa de Almeida - UFES

Profa. Dra. Annita Costa Malufe - PUC-SP

Prof. Dr. Alex Fabiano Correia Jardim - UNIMONTES 
A Regina Lúcia Pontieri, orientadora, pelo grande estímulo intelectual; aos professores Alex Fabiano Correia Jardim, Annita Costa Malufe, João Rezende, Júlia Maria Costa de Almeida, Marcos Piason Natali e Rejane Vecchia da Rocha e Silva, por muitas e distintas contribuições; aos colegas de pós-graduação, pelas conversas sobre filosofia e literatura; a CAPES, pelo apoio financeiro; a Roseli e ao Lorenzo, claro. 
Proust disse, e é bonito em Proust: não desejo uma mulher, desejo também uma paisagem envolta nessa mulher Gilles Deleuze, Abecedário 
RESUMO

A complicação deleuze-proustiana é um horizonte de incidência e emergência de ideias sobre a questão do pensamento. A fim de fazer jus a este horizonte, a presente tese examina as duas partes do livro Proust et les signes, animada tanto pelo que nele incide, reconstituindo e discutindo as suas formulações conceituais, quanto pelo que dele emerge, combinando a fotografia da explicação com o cinema da experiência, duas noções que, disparadas e fomentadas pela complicação, orientam aqui o próprio ato de examinar: ideia foto-cinema. É que, em qualquer instância, pensar não é apenas compactar exposições lineares e estáticas: além de surgir disparado e fomentado pelos signos emitidos por um objeto, o pensamento se desenha na dupla face da fixação e do movimento. Quando a tarefa ordinária, que remete apenas a um emaranhado de escolhas habituais e quebradiças, expõe-se à imprevisibilidade de um encontro extraordinário, os disparadores e fomentadores, que não são o objeto, mas os seus signos, não produzem outra coisa senão um sentimento de obrigação, a necessidade de um trabalho do pensamento; tudo aí se desdobra num exercício que tanto tematiza o outro quanto se torna ele mesmo uma verdadeira prática, um funcionamento: tríplice fronteira, jazz, lentidão e excesso. A questão, pois, nunca é a de estritamente inventariar o que é, afinal, Deleuze com Proust, dominando-o com arcadas mãos, mas a de assumi-lo como um território íntimo de signos, propício para uma espécie de cultivo livre que se faz desigualmente sobre e com ele, dinâmica funcional invariavelmente desejada e perseguida. 
The deleuzian-proustian complication is an occurrence and emergency horizon of ideas concerning thought. In order to do justice to this horizon, this thesis examines both parts of Proust et les signes, encouraged not only by what occurs on it, through reconstitution and discussion of its conceptual formulations, but also by what emerges of it, combining photography of explanation with cinema of experience, two notions that, triggered and fomented by complication, guide herein the very act of examining: photo-cinema idea. It is just that thought is, in any instance, not only about compacting linear and inert statements: apart from the fact that it arises triggered and fomented by signs emanating from an object, thought is drawn on the double side of fixation and movement. When the ordinary task, which only refers to a tangle of usual and brittle choices, exposes itself to the unpredictability of an extraordinary encounter, triggers and fomenters, which are not the object, but their signs, do not produce anything else but an obligation feeling, the need of mind work; everything there unfolds into an exercise that both broaches the other and turns itself into a real practice, an operation: triple border, jazz, slowness and excess. Therefore, the question is never about strictly inventorying what after all is Deleuze with Proust, mastering them with arched hands. It would be rather about assuming it as an intimate sign territory, fertile to a sort of free cultivation which unevenly makes itself about and with it, a functional dynamic invariably desired and pursued.

Keywords: Signs, Thought, Antilogos, Transversality, Photo-cinema idea. 
RÉSUMÉ

La complication deleuze-proustienne est un horizon d'incidence et d'émergence d'idées sur la question de la pensée. A fin de tenir compte de cet horizon, cette thèse examine les deux parties du livre Proust et les signes, ayant comme animation, d'un côté ce qui y survient, en reconstituant et en discutant ses formulations conceptuelles, et, d'un autre côté ce qui en émerge, en combinant la photographie de l'explication avec le cinéma de l'expérience, deux notions qui, tirées et motivées par la complication, guident ici l'acte d'examiner en soi: l'idée photo-cinéma. En fait, dans n'importe quelle instance, penser ne se limite pas à compacter des expositions linéaires et statiques: au delà d'apparaitre tirée et motivée par les signes émis par un objet, la pensée se dessine dans la double face de la fixation et du mouvement. Quand la tâche ordinaire, qui ne remet qu'à un enchevêtré de choix habituels et cassants, s'expose à l'imprévisibilité d'une rencontre extraordinaire, les tireurs et les motivateurs, qui ne sont pas l'objet, mais ses signes, ne produisent autre chose que le sentiment d'obligation, la nécessité d'un travail de la pensée ; ici tout se déploie dans un exercice qui à la fois thématise l'autre et devient lui-même une véritable pratique, un fonctionnement : triple frontière, jazz, lenteur et excès. La question, donc, n'est jamais celle de strictement inventorier ce qui est, finalement, Deleuze avec Proust, le maitrisant avec les paumes de mains, mais celle de l'assumer comme un territoire intime de signes, propice à une espèce de cultivation libre qui se fait inégalement sur et avec lui, dynamique fonctionnelle invariablement désirée et poursuivie.

Mots-clés: Signes, Pensée, Antilogos, Transversalité, Idée photo-cinéma. 
PS - Proust et les signes (edição francesa, tradução nossa)

PS(br) - Proust e os signos (edição brasileira)

$\mathrm{NF}$ - Nietzsche e a filosofia

$\mathrm{N}$ - Nietzsche

B - Bergsonismo

SM - Sacher-Masoch: o frio e o cruel

$\mathrm{DR}$ - Diferença e repetição

$\mathrm{AE}-O$ anti-Édipo

$\mathrm{K}$ - Kafka: para uma literatura menor

D - Diálogos

MP1 - Mil Platôs (vol. 1)

IT - A imagem-tempo

$\mathrm{C}-$ Conversações

$\mathrm{QF}-O$ que é a filosofia?

$\mathrm{CC}$ - Crítica e clínica

ID - A ilha deserta e outros textos

DRF - Deux régimes de fous

R-CS - No caminho de Swann

$\mathrm{R}-\mathrm{MF}$ - À sombra das moças em flor

R-CG - O caminho de Guermantes

R-SG - Sodoma e Gomorra

$\mathrm{R}-\mathrm{AP}$ - A prisioneira

$\mathrm{R}-\mathrm{AF}$ - A fugitiva

R-TR - O tempo recuperado 
SUMÁRIO

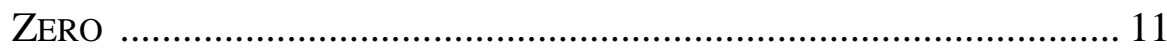

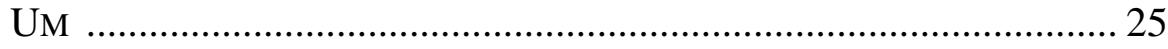

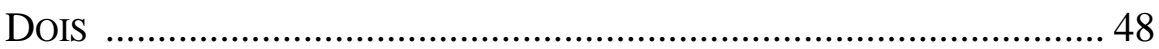

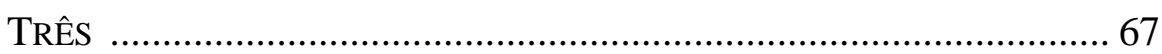

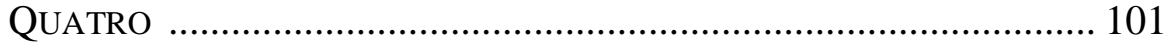

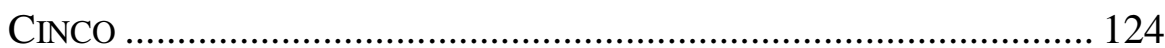

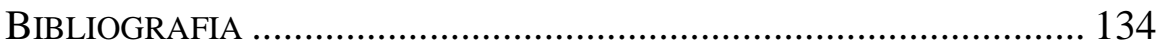


Dois compridos orelhões ou dois olhos suficientemente esbugalhados descobrem sempre o seu Midas; a Recherche, como aposta brevemente Dumoncel, talvez seja a chave para se entrar na filosofia de Deleuze, especialmente quando se tem em vista alguns aspectos de Différence et répétition, sendo a obra proustiana, neste caso, não menos do que a sua "expressão mais legível"1; se ele considerasse, assim, com Villani, que em certo sentido "todo Deleuze já está em Différence et répétition" "2, mesmo que à maneira de um germe ou de um ovo intenso, dourar-se-iam, de relance, chave e fechadura: nela, um pensamento que se desenvolve por encontros intensivos, permeando-se em saltos galácticos, como que a modular por inúmeros espasmos a experiência de um narrador-herói; nele, uma filosofia da diferença, pelo ambiente alvoroçado das vibro-variabilidades conceituais, sistema aberto, pluralista, deslizando em multiplicidades que não totalizam o pensamento. No que toca, porém, mais propriamente, o encontro deleuziano com a literatura proustiana em Proust et les signes, é possível retorcer, por outras vias, para o prazer dos ourives, essas satisfações conjuntivas, de cambulhada, sem desencerar os ouvidos nem lançar poeira aos olhos; não se trata, obviamente, de contrariar esse ou aquele esforço, mas de perceber, por um momento, que varar vidros e coitos, operadores funcionais comuns a Proust e Deleuze, permite sempre novas radiações e mobilizações, não mais nem menos conformes, simétricas, indigestas ou aberrantes, nas quais se considera, nos entreatos de um com estendido, um dinamismo pensante, como certas afluências aracnídeas: de algum ponto suspenso, a aranha solta um fio de seda; caminha sobre o fio, desatando outro, mais folgado; num lance, ela desce, o que a faz firmar um terceiro ponto de apoio, formando um triângulo; a partir do centro da teia, cria vários fios, conectando-os nas laterais; com a seda pegajosa, tece espirais logarítmicas. Esse filósofo-aranha, "sempre refazendo sua teia"3, descortina-se, deste modo, como o narradoraranha, cuja teia é a Recherche que se faz: "Sem olhos, sem nariz, sem boca, a aranha responde unicamente aos signos e é atingida pelo menor signo que atravessa seu corpo como

\footnotetext{
${ }^{1}$ Jean-Claude Dumoncel apud François Dosse (2010, p. 109).

${ }^{2}$ Arnaud Villani (2000, p. 40).

${ }^{3}$ Éric Alliez (1996, p. 37).
} 


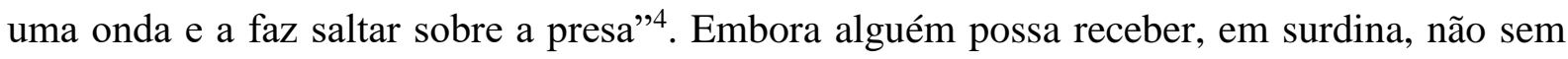
certo gosto por engenharias decorativas, essas noções funcionais por metáforas, é preciso reouvir, de passagem, a insistente advertência deleuziana pelo literal (tema difícil, uma vez trabalhado por Zourabichvili ${ }^{5}$ ), vendo na metáfora apenas um embuste, cuja refutação mais evidente não é outra senão a de seu uso: "Mas há também noções fundamentalmente inexatas e, no entanto, absolutamente rigorosas, das quais os cientistas não podem prescindir, e que

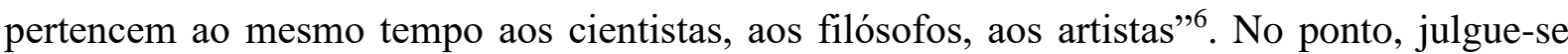
que a noção aranha-teia pertence, entre um Gilles Proust e um Marcel Deleuze, ao próprio dinamismo do pensamento em Proust et les signes, livro animado, pelo menos numa de suas numerosas mobilidades, pela questão signo-pensamento, quando toda tarefa ordinária se expõe à imprevisibilidade de um encontro extraordinário: ao fazer ou refazer uma teia, que remete apenas a um emaranhado de escolhas habituais e quebradiças, há a necessidade de uma vibração-mosca nervosa que se propague até o corpo-aranha, necessidade de uma inesperada cintilação que o afete no aqui e agora, visto que só há pensamento na medida em que um signo vem se pronunciar como uma espécie de imperativo.

Livro é, ou uma reunião de porções, como aranha-teia, por força de encontros, matizando-se conceitualmente de novos compostos, sem regime homogêneo, escrito ao longo de nove anos, com três edições diferentes (1964, 1970 e 1976), por soma de excertos, sempre nada definitivo, constituindo-se como experiência importante para a formulação de uma filosofia da diferença, entremeando livros pré e pós Guattari, atravessado no meio tanto por outros livros de Deleuze, como Le Bergsonisme, Différence et répétition e Logique du sens, quanto pela primeira produção deleuze-guattariana, L'Anti-Oedipe. As insistentes ampliações abrigam variegadas conjunções pensantes, realocando a cada vez certa taxonomia dos signos, o elemento articulador de uma constelação larga, para além de suas categorias constantemente transitivas; para Nabais, por isso, tais contorcionismos com os signos proustianos comportam, na verdade, três aproximações diferentes da Recherche: na primeira edição, um modelo quaternário; na segunda, um modelo ternário; na terceira, um modelo binário ${ }^{7}$. Livro é, de qualquer forma, com duas partes editoriais, "Os signos" e "A máquina literária", flexionando abundantes dispositivos, feito um maquinismo de peças, percorrendo duas grandes ordens de

\footnotetext{
${ }^{4}$ PS, p. $218-$ PS(br), p. 172-173.

${ }^{5}$ François Zourabichvili (2005, p. 1309-1321).

${ }^{6} \mathrm{C}, \mathrm{p} .42$.

${ }^{7}$ Catarina Pombo Nabais (2013, p. 47-54).
} 
problemas, como Deleuze as expõe no "Prefácio à terceira edição": na primeira parte, o problema da emissão e interpretação dos signos tais como eles se apresentam na Recherche; na segunda, o problema da produção e multiplicação dos próprios signos, do ponto de vista da composição da Recherche ${ }^{8}$. Tal distinção interna, visto que há, entre as partes, vibrações e variações conceituais, permite ser incorporada nas noções mútuas de vidros e coitos, figurando aquém ou além do formato editorial, nas quais a convenção do impresso transborda. Desenha-se com a Recherche, talvez, jazzisticamente, uma arquitetura plural de notas, uma engrenagem articulada pela qual Proust, em cada caso, pode ser diferentemente enrabado, como em outros fazia Nietzsche, o fazedor de filhos pelas costas. As partes não são instâncias lineares e estáticas que se encaixam para finalizar um exame (peças harmoniosas de um estudo com começo, meio e fim), mas expressões heterogêneas de uma condição filosófica que, contra qualquer rotinização, exige movimentos e clivagens. Como que estabelecendo o direito de um pensamento-pathos, tem-se nelas uma transfiguração contínua, que se justifica, é claro, nas alomorfias experienciais do filósofo durante o período de nove anos, com a fracionada história editorial do livro, mas também, especialmente, na própria vibrovariabilidade do pensamento deleuziano, banhado e movido pelo óleo dos encontros. O que diretamente as liga, fazendo-as comunicantes, é uma espécie de fotografia-vidro, como a da taxonomia dos signos, não desmentida nas duas partes, embora vibrando de quando em quando com contornos peculiares; o que diretamente as desliga, mas já as religa de outras maneiras, sem lhes suprimir a diferença e a independência, é uma espécie de cinema-coito, tomado por variações conceituais, como a que fecunda, no bojo do problema da produção e da multiplicação dos próprios signos, o conceito de transversalidade, providencialmente tomado de Guattari e inserido na segunda edição: na primeira parte, “Os signos”, em 1964, "pensar é sempre interpretar, ou seja, explicar, desenvolver, decifrar, traduzir um signo"9; na segunda, “A máquina literária”, em 1970, "o interpretar só tem uma unidade transversal”10.

Se o conjunto deleuze-guattariano dos Mille plateaux se coloca como anéis quebrados que podem penetrar uns nos outros, se bem que cada um tenha um clima, um tom ou um timbre próprio, a arquitetura de partes em Proust et les signes pode ser compreendida, talvez,

\footnotetext{
8 Tem-se, deste modo, a publicação das partes de Proust et les signes: em 1964, "Os signos"; em 1970, "Os signos" e "A máquina literária"; em 1976, "Os signos" e "A máquina literária" (incluindo o texto "Presença e função da loucura. A aranha", que fora publicado avulsamente em 1973, remanejado agora como conclusão da segunda parte).

${ }^{9}$ PS, p. 119 - PS(br), p. 91.

${ }^{10}$ PS, p. $156-$ PS(br), p. 122
} 
como um móbile, esse não livro do próprio livro, tendo-se que a sua forma intensiva é a das partes que, em vez de simplesmente se unificarem, afirmam-se em dobragens: duas grandes peças principais se movimentando, conectadas, porém, a uma infinidade de pequenas peças, combinando fixações e movimentos, sem que possam ser domesticadas completamente por uma ideia-foto. No dinamismo das partes, uma página da primeira não se pareia exatamente como iniciação de uma página da segunda; ambas se movimentam, dando-se ao ar em trânsito, podendo o pensamento ser atualizado, modificado ou assumir relações diversas para compor uma rede pluriarticulada de conexões, embora não deixando de se conduzir, no sentido musical das três edições, por uma mecânica precisa - como, aliás, são os temas melódicos para o jazz, atravessados ou contornados por irreverentes improvisações, em notável compromisso tático. Tendo algumas roldanas, polias e dobradiças, reveladas na arquitetura tanto pela engrenagem dos capítulos e conclusões quanto pelas circunstâncias de o pensamento realizar certos acoplamentos, ela aspira, no entanto, um nomadismo que realiza visitas sem se fazer hóspede, tornando-se vulnerável volta e meia a interferências ou vírus fortuitos; isso se vê no modo particular das partes caminharem com Proust, tal como as esculturas moventes de Jansen, levadas pelo vento, ou os móbiles de Calder, agitando-se como ramagens ou caudas flexíveis, que mesclam a fixidez da engenharia montada com a vulnerabilidade da direção no movimento. Quando o equipamento funciona com esses ou aqueles componentes, o mesmo já não é o Mesmo, pois povoado por vibrações e variações; cada parte agregada ao livro, sem jogo de causalidade ou determinismo, pode se apresentar enquanto introversão ou extroversão da precedente - tal qual a "Conclusão" editorial da segunda parte, conclusão que, de fato, não a conclui, movimentando-se entre a loucura de Charlus e Albertine e o problema do narrador-aranha. Na verdade, todo o Deleuze com Proust, incluindo então os textos de ocasião, como "Table ronde sur Proust" (1975) e “Occuper sans compter: Boulez, Proust e les temps" (1986), mas também as numerosas complicações deleuze-proustianas que, enquanto ciclismo de relações entre filosofia e literatura, aparecem ao longo de toda a obra filosófica, é nada definitivo; move-se como um aparelho articulado, que se reposiciona provisoriamente e se retorce, por um ar eventual que passa, desprendendo de si, talvez, pinos e arruelas, distanciando-se, pois, de qualquer pretensão industriosa, ainda que sempre sustentando a Recherche como "uma semiologia geral, uma sintomatologia dos mundos"11; da seguinte forma o compreende Chaudier, ao

${ }^{11}$ C, p. 182. 
comentar os textos proustianos do filósofo: "O gesto que consiste em ligar, hierarquizar e vetorizar o diálogo vivo para dar-lhe coerência é estranho a Deleuze" ${ }^{\text {" }}$. O que se vê em Proust de certa maneira faz careta nele, implicando o modo de uma unidade que não é lógica nem orgânica, não pressuposta ou prefigurada pelas partes; faz-se, como a que conduz em Proust a passagem de uma Albertine a outra Albertine, visto que tal mulher possui múltiplas almas e faces, assim, transversalmente, como se define uma dimensão transversal: "É ela que permite, num trem, não unificar os pontos de vista de uma paisagem, mas fazê-los comunicar segundo sua dimensão própria, em sua dimensão própria, enquanto eles permanecem nãocomunicantes segundo as deles"13. De outro modo, as rítmicas que o pontuam não são propriamente as de um modelo quaternário, ternário e binário, mas as das diferenças livres, que se ligam e religam indefinidamente, e as das repetições complexas, que se revelam feito ondulações vibratórias: "nada é mais perturbador que os movimentos incessantes do que parece imóvel"14. É o que grita na página-fuga e na página-ovo, com as rupturas, os hiatos, as lacunas e as intermitências dos antilogos deleuziano e proustiano, abrindo-se, aparentemente, como aparecem nomeadas na segunda parte do livro, a uma figura de relações continenteconteúdo, pela imagem de "caixas entreabertas", que funcionam por encaixe, envolvimento ou implicação, e a uma figura de relações partes-todo, pela imagem de "vasos fechados", que funcionam por complicação.

Como se entra nesse móbile de válvulas, manivelas e carretéis, ainda que se esteja muitíssimo distante dos movimentos mais viscerais de um L'Anti-Oedipe ou de um Mille plateaux? Entra-se por qualquer lado, pelos enormes braços metálicos que sustentam as bobinas laterais ou pelos sulcos em hélice de um ínfimo parafuso, e se tem sempre o mesmo desafio: por um lado, não cimentar as molas para simplesmente produzir a estátua exigida pelo protocolo laboratorial, ou, o que é a mesma coisa, não betumar milhentas vezes as alavancas para corroborar somente a solenidade da explicação (a hipótese tal, fotografada), em detrimento das lutas intestinas da experiência (a hipótese tal, filmada); por outro lado, não mimetizar os acoplamentos e o nomadismo da máquina para meramente produzir uma sombra entrosada, aquela familiaridade presumida, vertendo espelhamentos, equivalências e

\footnotetext{
${ }^{12}$ Stéphane Chaudier (2007, p. 86).

${ }^{13}$ PS, p. 201-202 - PS(br), p. 160.

${ }^{14}$ C, p. 200.
} 
similaridades linguageiras, incapacitando-se, nisso, à explicação (a fotografia diluída no filme). O didatismo estéril ou a exegese desencarnada, pretensamente neutra ou distante, cujo vício expositivo, obsessão tecnicista ou pretensão tecnocrata elimina, metodicamente, qualquer construtivismo experiencial, é tão dispensável quanto o adesismo rocambolesco, puramente decorativo, a filosofemas, frases ou expressões do filósofo, como que fazendo das bordas e orlas o seu máximo limite; ambas as práticas funcionam, por assim dizer, como um homem pensativo que, numa noite, à beira da fogueira, tendo deitado o seu chapéu sobre o joelho, em duvidosa sonolência, deixa-se enredar pelo brilho do fogo ou pelas imagens oníricas que dele emanam. Pressente-se, aliás, onde estão as condições pelas quais se pode superar, nos termos de Zourabichvili, a falsa alternativa de expor ou utilizar o pensamento de Deleuze: "a exposição dos conceitos é a única garantia de um encontro com um pensamento", uma oportunidade de encontro, mas "sob a dupla condição do simpático e do estranho, nos antípodas tanto do desconhecimento como da imersão" ${ }^{15}$. Donde se faria também qualquer facilidade de ser deleuziano, situação projetada certa vez por Foucault, a despeito de seu "humor diabólico"16, no famoso vaticínio "um dia, talvez, o século será deleuziano" "17, faz-se, na verdade, a mais completa dificuldade de ser deleuziano: a generosidade desse pensamento, assim que alguém se mantém atraído nele, está justamente em, num certo sentido, excluir tudo o que não seja ele próprio e, ao mesmo tempo, toda obstinação ou persistência de discipulagem, tudo o que não seja uma atividade igualmente criadora. "Ninguém é deleuziano", diz Rolnik, entre muitos outros: "Talvez a força maior do pensamento de Deleuze esteja justamente em criar condições para convocar no leitor a potência do pensamento. Quando isto acontece, a produção do leitor será necessariamente singular e, portanto, jamais 'deleuziana ""18. Isso significa que o que torna os textos de Deleuze legíveis é a posição desde a qual o leitor os pensa; não é indevido, aliás, trocar o modesto "leitor" pelo ostensivo "leitor-usuário-traidor", pois os textos fazem sentido se alguém os toma como elementos de um processo de elaboração e articulação de problemas que lhe são próprios; embarca-se neles, pois, a partir de questões que pedem passagem na existência de cada um, questões sempre circunstanciais ou singulares, como será circunstancial ou singular o estilo através do qual elas poderão ser problematizadas. Eis então a posição desde a qual aqui se

\footnotetext{
${ }^{15}$ François Zourabichvili (2009, p. 11).

${ }^{16}$ C, p. 115.

${ }^{17}$ Michel Foucault (2008, p. 230).

${ }^{18}$ Suely Rolnik (1995, p. 6).
} 
pensa, o problema que é próprio ou a questão que pede passagem, não sem se lambuzar no risco de sobrepujar monstruosos polimorfismos com pretensiosas simplificações: em que consiste (incidência de ideias) e o que dispara (emergência de ideias) o encontro deleuziano com a literatura proustiana em Proust et les signes?

Em primeiro lugar, deve-se apreender que se trata de um estado complicado esse encontro, filosofia em aliança com a literatura, domínios que se cortejam, remendando-se ou costurando-se por uma rede de fios: a co-implicação, uma implicação recíproca; o cofuncionamento, um funcionamento recíproco. O conceito de complicação, segundo um de seus sentidos em Deleuze, exprime um estado, o das diferenças (domínios, séries, intensidades, singularidades) envolvidas ou implicadas umas nas outras, correspondendo a uma espécie de "encontro disjuntivo", avesso à mera fusão. Chame-se de complicação deleuze-proustiana tal encontro: ela se faz como um andar de bicicleta, equivalendo o peso e a inclinação do ciclista ao peso e à velocidade do veículo, a posição dos braços e das pernas à posição do guidão e das rodas. Há um nível de comando do ciclista, envolvendo a definição de direções e caminhos, mas também há um nível de comando da bicicleta, com as suas exigências físicas, materiais, mecânicas, aerodinâmicas. O corpo do ciclista, vulnerável, sem cabine nem vagão, mas inteiramente aliado ao quadro do veículo, caracteriza-se pela abertura dos sentidos, dada a necessidade de ele estar atento ao vento, aos buracos, às poças d'água, combinando os seus movimentos equilibrantes com os movimentos da estrutura de duas rodas. $\mathrm{O}$ ciclista e a bicicleta formam, assim, uma aliança que se torna possível pela maneira com que eles entram em conexão, que não é exatamente unidade; é um tipo estranho de relação mútua que insiste em todos os graus, definindo velocidades, lentidões, acelerações, desacelerações. Em segundo lugar, deve-se apreender que, em seu aspecto decisivo, Deleuze não fala sobre Proust, mas com Proust, operando conceitualmente. A complicação deleuzeproustiana consiste, mais propriamente, em transformar em conceitos o exercício não conceitual de pensamento que existe na Recherche: a literatura os suscita e o filósofo os esculpe, como criação filosófica - a serviço, é claro, de seu banditismo e de sua enrabada, escondendo aquilo que não lhe interessa e superestimando aquilo que the interessa, fazendo "um filho pelas costas" (situação mais do que suficiente para não ser reivindicada como severa análise literária). É um modo peculiar de caminhar com a obra proustiana, conceitualmente comprometido, um falar com; nessas palavras o registra Orlandi: "Essa leitura, não sobreposta, procura instalar-se na própria atmosfera de modulação literária e 
conceitual de signos propensantes, desliza numa zona de ressonâncias"19. Com efeito, um pensamento com a Recherche não é um pensamento sobre a Recherche, mas sobre os conceitos que a Recherche suscita (signo, imagem do pensamento, antilogos, transversalidade etc). De pronto, essa posição de prática assumida pelo filósofo se choca com o paradoxo de outra condição, a do crítico literário, quando entendido como aquele que fala somente sobre; "quando entendido", pois é verdade que o problema do crítico toma o hábito de vaguear em sortidos cômodos, não se dissolvendo numa rançosa e caduca querela terminológica nem em entidades proverbiais arrojadas. Em geral, nos contornos de um esforço muitíssimo engajado, definir o crítico depende de algo que nunca se quer, isto é, um dogma que o determine e o classifique permanente e universalmente como tal; a dificuldade mesma de defini-lo (quem é, quem não) permite imaginar que, em produto, talvez ele possa se mesclar em conceitos, funções e sensações, numa híbrida fantasmocrítica, recusando céus ou infernos eternos; é que, se as tábuas sagradas falham, não se deve depreciar a hipótese de que, nos mais variados murmúrios de suas tarefas, algum tipo de crítico, mesmo se ainda lhe for dado esse nome, possa ser ora filósofo, ora cientista, ora artista. De qualquer forma, deve-se distinguir, por comodidade, não sem alguma carência de aprofundamento, que um crítico literário, no sentido convencional, reflete sobre a literatura, enquanto que esse filósofo, em sentido decisivo, cria conceitos com a literatura.

Evidentemente, o encontro deleuze-proustiano exige um exame das articulações pelas quais filosofia e literatura nele se complicam. Trata-se, pois, de examinar, nas duas partes de Proust et les signes, por encarnação, eliminando qualquer hipótese de defesa ou detração do filósofo, o modo pelo qual algo em estado de arte suscita algo em estado de conceito, o que envolve transitar tanto na filosofia de Deleuze quanto na literatura de Proust. Aqui, porém, deve-se compreender "exame" numa perspectiva estendida, como uma dinâmica funcional invariavelmente desejada e perseguida, nunca como uma promessa: em primeiro lugar, exame como uma atividade que se põe ao mesmo tempo sobre e com Deleuze com Proust, cuja boa forma deve ser a de ver Proust et les signes tanto como um horizonte de incidência de ideias quanto como um horizonte de emergência de ideias; em segundo lugar, exame como uma atividade transdisciplinar, mais à moda de Guattari, talvez, do que à moda de Piaget; em terceiro lugar, exame como uma atividade de autoexame, voltado à singularidade de sua própria língua-pensamento, por repelir a ideia de que existe somente uma forma de desenho

${ }^{19}$ Luiz Orlandi (1996, p. 110). 
para o pensamento; enfim, em quarto lugar, exame como uma atividade de não descomplicar aquilo que está em complicação. A dimensão do sobre e com Deleuze com Proust se vincula a uma disposição adequada do par explicação-experiência; tudo se desdobra num exercício que tanto tematiza o outro quanto se torna ele mesmo uma verdadeira prática, um funcionamento: tríplice fronteira, jazz, lentidão e excesso. Que apareça a geração dos criadores de numerosas práticas ou funcionamentos, não limitados ao âmbito do inventário, é a exigência do presente e do futuro: não é ilícito imaginar que, em pouco tempo, alguma espécie de ideia-google, desde que implicando uma invenção automática de linguagem (rastreamento, investigação e opinião própria), poderá fazer roboticamente todo o inventário possível. A transdisciplinaridade, no sentido de Piaget, não organiza discursos disciplinares isolados (multidisciplinaridade) nem os reúne num discurso estável (interdisciplinaridade), visto que nela as disciplinas figuram em permanente rotação, formando uma zona volúvel, estando dissolvida a solidez das regiões demarcatórias originais: "pode-se esperar uma etapa superior que seria 'transdisciplinar', que não se contentaria em atingir interações ou reciprocidades entre pesquisas especializadas, mas situaria essas ligações no interior de um sistema total, sem fronteiras estáveis entre as disciplinas" 20 . No sentido de Guattari, contudo, há uma visada política que transcende de certa forma todas as convenções institucionais; agora, a transdiciplinaridade livra o exame da disciplinarização, fomenta um movimento "através de", uma necessária produção integradora, uma comunicação efetiva com a vida; promove, em suma, um gosto de "ir além" da organização institucional do pensamento: "o gosto pelo risco, a fuga de esquemas pré-estabelecidos, a maturidade da personalidade" ${ }^{21}$. Ela é, assim, uma modalidade transversal, significando, em sentido profundo, o abandono dos verticalismos e horizontalismos da árvore, aliada aos fluxos rizomáticos que, num instante, podem tomar qualquer direção (conhecimento científico, expressões corporais, culinária coletiva, experiência poética, desprendimento afetivo, como se pretendeu viver na Clinique de La Borde). Em outras palavras, a transdisciplinaridade guattariana (modalidade transversal), conforme apresentada, por exemplo, em Psychanalyse et transversalité, implica escapar da verticalidade dos organogramas piramidais das instituições e da horizontalidade massificante que estabelece agrupamentos homogêneos de saberes e indivíduos. $\mathrm{O}$ exame aí se põe como uma aventura certamente desprotegida, pois realizado em ambiente largo ou elástico; mas,

\footnotetext{
20 Jean Piaget (1972, p. 144).

${ }^{21}$ Félix Guattari (1992, p. 29).
} 
afinal, a quem serviria um ambiente estreito ou rígido, seja nos estudos literários, seja nos estudos filosóficos, senão àqueles que, contrários à aventura do pensamento, precisam encontrar uma superproteção numa superdisciplinarização? Junte-se a esse desejo de transdisciplinaridade a dimensão do autoexame: evitando a simples engorda ou uniformização de blocos expositivos, há a exigência de que o exame volta e meia se examine, pense sobre o seu próprio desenho de pensamento, chegue, talvez, à segunda onda, que é o seu mundo em processo, em movimento, em cinema; não havendo nas coisas verdades substanciais ou suprahistóricas, tampouco imutáveis modelos únicos, o pensamento precisa sondar como deseja se fazer, como está se fazendo, como deixou de se fazer, como se fez. Enfim, é viável manter complicado o que em Proust et les signes não está descomplicado, o pensamento de Deleuze, o pensamento de Proust. Por conta da complicação, não se trata de perguntar o que realmente pertence a Proust e o que vem de Deleuze, ainda que no ambiente deleuze-proustiano se possa identificar, além da literatura proustiana, um conjunto de problemáticas genuinamente deleuzianas: signo (problema que é mantido em interesse em várias obras), sentido (problema que recebe um desenvolvimento significativo em Logique du sens), imagem do pensamento (problema que atravessa toda a obra de Deleuze e Deleuze-Guattari), aprendizagem (problema que é longamente retomado, por exemplo, em Différence et répétition), essências (problema que Deleuze abandona nas obras subsequentes, mas que já em Proust et les signes recebe um sentido não platônico, como diferença), estilo (problema que se apresenta em livros como Dialogues, Mille plateaux, Qu'est-ce que la philosophie? e Critique et clinique). É irrelevante, afinal, separar aquilo que, numa situação específica, está explicitamente em aliança (a filosofia, a literatura), aquilo que se mistura, aliás, nos próprios mecanismos de linguagem que ali se desdobram, muitíssimas vezes sem a polidez das aspas, encarnando, como questões filosóficas, selecionadas questões literárias. Deve-se deixar no colo do filósofo, desde que ele se relaciona complicadamente com o pensamento proustiano, toda a responsabilidade por qualquer confusão: ladrão, que o leva para uma casa filosófica; fazedor de filhos pelas costas, que o engravida com um filho-monstro.

Que todo exame já pertença a um mapa de criação se explica facilmente: da solenidade da explicação às lutas intestinas da experiência, substituindo a determinação do centro pela determinação do ponto de vista, há problemas de maquinação, de maquinar os textos de Deleuze, de encontrar o que dá a tal ou qual frase dele outra coisa, de modo que alguma coisa passe (não é exagerado dizer, sem dedos, que Deleuze com Nietzsche grita em Deleuze com 
Proust $^{22}$ ). O encontro com um pensamento não reprime engates nem contaminações que porventura se apresentem por bandidagens e enrabadas afins, como se pega uma matéria primeira numa geografia de pensamento primária e, ativando a receptividade de suas angulações diferentes, já se lhe apresenta metamorfoseada como matéria segunda numa geografia de pensamento secundária: toda esta indispensável gravidez clandestina, feita ao ar livre, toda esta liberdade que os meios institucionais de decodificação, domados por uma irrefreável lógica do inventário, tomam por infiel, parcial ou profana. Deleuze mesmo expressa o que é não repetir o que disse um pensador, mas dizer o que ele subentendia necessariamente, o que ele não dizia e que, porém, está presente no que ele dizia: "Eu me imaginava chegando pelas costas de um autor e lhe fazendo um filho, que seria seu, e, no entanto, seria monstruoso" ${ }^{23}$. É nesse sentido, aliás, que, com a literatura, Proust et les signes persegue a geração de um filho-monstro: é caso a não ser conferido ou comprovado nos genes da Recherche, pois rebentando de uma complicação que, em sentido decisivo, visa fabricar conceitos, não redundando em policiamentos entre os domínios; é caso, sobretudo, a não ser superestimado como solução para os difíceis problemas proustianos, pois se transviando de qualquer especialização pretensiosa, aquela que, por uma política de provas e confrontações paginadas, a despeito do desconforto de poder ser continuamente desmentida pelas indomáveis violências da arte, registra os seus rebentos no cartório da legitimidade, adornando-os, assim, com honrosos carimbos, para depois, benta de lágrimas, tomá-los em braços fraternais, com todas as pompas dos bebês não pagãos ou batizados - guirlandas, bichinhos de pelúcia, mamadeiras e chupetas coloridas. No corte, no caimento e na costura, a oportunidade de examinar é a oportunidade de criar; aqui, no fundo, nunca é menos do que deleuzianamente roubá-lo: "Roubar é o contrário de plagiar, de copiar, de imitar ou de fazer como. A captura é sempre uma dupla-captura, o roubo, um duplo-roubo. É assim que se cria, não algo de mútuo, mas um bloco assimétrico, uma evolução a-paralela, núpcias, sempre 'fora' e 'entre'"24. Exposição e roubo, traição, humor; como um Zen, é preciso buscar o caminho do meio: não se trata apenas de referir ideias fidedignas, como que a presentear o filósofo com o melhor acabamento, um petit cadeau; trata-se também de criar, eventualmente, ideias livres, abertas à novidade inexpugnável do inexistente, indo até onde as tarefas são menos viscosas e insalubres, como intervenções experienciais que independem de um

22 ID, "Pensamento nômade", p. 324.

${ }^{23}$ C, p. 14.

24 D, p. 17. 
veredicto. É válido rir, no calcanhar do sono ou da insônia, pelo canto da boca; estranha é a comunidade que, num decoro congressista, devidamente paramentada, talvez, com botas, esporas e chicotes, diviniza ou demoniza intervenções dissonantes sob a categoria positivista da descoberta, com indômitas pretensões de evolução perene, tendo-as precipitadamente como manifestações de um único princípio de manejo, o manejo "certo", dito "acadêmico", embora sendo mil os óculos; discute-se, pressupõe-se uma arquiescritura, como se o filósofo resplandecesse ileso aos processos de apropriação; tem-se um parti pris, o de que, num nobre lugar, há o reino da verdade sem bordas retalhadas, suposto retiro indevassável no qual é possível se resguardar castamente, ao rés do objeto; com efeito, no capricho, ao sabor das circunstâncias, delimita-se até a novidade, qualquer espectro na liturgia, a partir de um esquema de coordenadas vistas como naturalmente universais, sem que se cite a regra pseudocientificista que aí se compõe: crer apenas naquilo que, evitando a prolixidade, "organiza", "coteja" e "reflete", ainda que por nenhum ato criador.

Como o pensamento se desenha? Qualquer exame, feito de sólidos bem talhados, vigas bem encaixadas, relacionando ainda os comentaristas em pontos precisos, cumpre bem as convenções e as cerimônias; contudo, ele pode, de repente, não chegar à segunda onda, que é o seu mundo em processo, passagem da coisa a interpretar à arte de interpretar, dramatizando o com com o com (com Deleuze com Proust). Quando se observa lentamente uma onda, percebe-se que, entre os véus de espuma, muitíssimas gotas ambulantes, montando-se e desmontando-se, constantes ou episódicas, formando desenhos sobre desenhos, isto é, segundas ou terceiras ondas, transladando-se velozmente em minúsculos orbitais, cuja fragilidade não raramente decanta a fortaleza do todo, são o que na verdade a constitui; elas agem sem simpatia, por rigorosos espasmos, sem exprimirem um todo de onde teriam sido arrancadas, ainda que sem ambição aforística, como que num diálogo de inconciliáveis universos, engatando todas as embolações e todos os rodeios aquáticos necessários, até que o observador possa intempestivamente considerar: que necessidade teria a onda, apenas uma totalidade estatística, quando as gotículas ambulantes são o seu processo? É certo que não há apenas uma forma de o pensamento se desenhar, o que torna tudo bastante complicado, uma verdadeira torre de babel. Entretanto, num reducionismo didático, é possível dizer que o pensamento se desenha variavelmente pela orientação de uma ideia-foto e pela orientação de uma ideia-cinema: a primeira diz respeito à fixação do pensamento no âmbito da explicação, da exposição, da informação ou da comunicação, instância na qual as coisas devem ganhar 
alguma solidez ou consistência; a segunda diz respeito à dinamização do pensamento no âmbito da experiência, do processo, da flutuação ou do movimento, instância na qual as coisas jamais ganham solidez ou consistência. Tudo varia para mais ou para menos; qualquer literatura, por exemplo, do ponto de vista de um desenho de pensamento, põe-se mais como experiência do que como explicação. Abraçando uma onda pelos quadris ou lambendo as suas bainhas, tal mundo em processo revela que as exposições aderentes, se não pulverizadas em vídeo, progridem rapidamente como verdades intocáveis, tomando um efeito constrangedor, como ortodoxia teológica; é que elas, fundamentadas apenas numa ideia-foto, tendem a lidar com quadros lineares e estáticos, representações fixas do objeto, fugindo-lhe tudo o que constitutivamente se relaciona em animação. A essa boa dificuldade se junta outra, não querida, como diz Orlandi, mas que se intromete na prática escolar ou professoral; trata-se do já citado "didatismo", que sempre ameaça transformar o sistema filosófico deleuziano e deleuze-guattariano, que se pensa multilinear, em arborescente "sistema pontual" 25 . Quer-se evitar depressa tudo isso? Evidentemente, evidentemente. Daí que, por vezes, em qualquer sistema de pensamento, somente uma espécie de escrita arrogante ou estrangeira, sem nunca se sacrificar às pretensões do todo, gerando a determinação em si mesma, irredutível a retilíneas significações discursivas, ainda que estimulando radicalmente o pensamento, escrita-ninfa-fluxo, "algo de intensivo, de instantâneo e de mutante, entre uma criação e uma destruição" 26 , um pouco à fresca e à solta, sem toga nem estola, possa revolver os caldos da sua própria silhueta (por outras vias, aliás, introduziu Nietzsche o aforismo e o poema na filosofia, demandando "uma nova concepção da filosofia, uma nova imagem do pensador e do pensamento"27). Nela, a despeito das resistências de uma possível racionalidade que parcialmente naturaliza preconceitos, estereótipos e clichês demeritórios acerca de tudo o que não é convencional, deve existir algum atletismo filosófico, científico e artístico, não teso, engomado ou chocho, um novelo de forças com pontas sempre abertas, engatando-se vez a vez em novas relações; deve haver um labirinto de fixações e movimentos, que se resolva não apenas numa ideia-foto, aquela pela qual se notabiliza toda a explicação laboratorial, as superfícies de contato, a fruição de determinados problemas, a vibração de linhas entre um $a$ e um $b$, mas também numa ideia-cinema, aquela pela qual se notabiliza toda a experiência lógica, a liberdade livre, o enredamento em diversas direções, a variação de redes

\footnotetext{
${ }^{25}$ Luiz Orlandi (2010, p. 129).

${ }^{26} \mathrm{D}, 66$.

${ }^{27}$ N, p. 17.
} 
entrecruzadas, $a$ e $a^{1}, b$ e $b^{1}, c$ e $c^{1}$ : ideia foto-cinema. Ao se anuviarem as brochuras que prescrevem como digna apenas uma forma de desenhar o pensamento, a linear que, ao comportar centralidades de significância, mantém-se estática, não ocorre, no andamento de um exame explicitamente comprometido em foto-cinematografia, engessamento sem rápido derretimento; desfaz-se, enfim, nos borboleteios ou na falsíssima rigidez das afirmações, aquela possibilidade de domesticação e terminação numa estátua protocolar, aquele domínio do filósofo pela comodidade da síntese e da conclusão, como que roubando o encanto cinematográfico das minúcias ziguezagueantes, ou, o que é a mesma coisa, desfaz-se aquela possibilidade de reduzir tudo a um calvinismo. Certamente, o que se tem com isso pode significar perda para muitos, que lamentam ou protestam, chamando a polícia e pedindo ordem (clareza, objetividade, concisão); se os agrada, paga-os o labirinto, devidamente, com a moeda flutuante dos movimentos; se não os agrada, paga-os, talvez, machadianamente, pois as pilhérias não têm outro objetivo senão o de pilheriar, com um piparote, e adeus. 


\section{UM}

Proust et les signes é um livro de filosofia, não se separando de outros livros de Deleuze e Deleuze-Guattari, ressoando-os, transversalmente. O filósofo tem ao longo de suas obras operações recorrentes, mas em mosaico, fabricadas em experimentações ambulantes, por força de encontros intensivos, onde fluxos se multiplicam, tais quais dobras, desdobras e redobras, em vibrações e variações conceituais, sendo os conceitos elementos múltiplos, numa coerência por vir, como uma criação em estado selvagem, em desequilíbrio relativamente a ela própria, o Erewhon de Butler: ao mesmo tempo no-where, o lugar nenhum originário, e now-here, o aqui e agora subvertido ${ }^{28}$. Tem-se que a sua lógica é de certo tipo sísmico, atravessada, cá, lá, por séries de rajadas e abalos, nervuras polimórficas, donde não é muito dizer que as intempéries se tornam halteres, não implicando totalizações organicistas, ou de certo tipo hidráulico, rebelde a simplificações torneadas pela grosseria das generalizações, constituindo-se em torno do fluido e não do estático, não tornando os conceitos necessariamente mais apurados, não se domesticando em meras conformidades, não se encapsulando num dispêndio uniforme, não sem dissonâncias, enfim. Duas noções funcionais, a dos espelhos e a dos coitos, multiplicadoras por excelência, podem transitar normalmente entre quaisquer não apartados; mas nele, enquanto a dos coitos certamente satisfaz por conta de sua liberdade livre, a dos espelhos não é uma boa noção, pois redimida demais pelas presilhas do duplo, feito cópia ou apêndice, mesmo quando se sabe que os espelhos, associados como objetos para outros espelhos, multiplicam e retorcem deveras as imagens; há de se ter a dos vidros, que são superfícies de contato, lentes sem retenção, detendo, em sua tela opaca ou lúcida, apenas a natureza fluída das aparições, os perfis e os vapores ligeiros dos operadores transeuntes ou passantes; assim, no entre livros, vidros e coitos, aqui, como noções funcionais para as vibrações e variações conceituais deleuzianas. Por um lado, a dos vidros, na qual o que está em um livro multiplica, por contato, o que está em outros, provendo-o com novas radiações, mas numa direção transparente, dando prerrogativa à fruição de determinados problemas; por outro lado, a dos coitos, na qual o que está em um livro multiplica, por fecundação, o que está em outros, enredando-o em incomputáveis

${ }^{28}$ DR, p. 17-18; ID, "Sobre Nietzsche e a imagem do pensamento", p. 182. 
direções, vez a vez num movimento inesperado. Que a multiplicação do vidro é menos complexa do que a do coito se faz notório, a despeito da prática de ambas em conjunto: enquanto o vidro é uma espécie de situação fotográfica que vibra linhas entre, por assim dizer, um $a$ e um $b$ (por exemplo, a gênese da noologia ou dos estudos das imagens do pensamento em Nietzsche et la philosophie, Proust et les signes e Différence et répétition), o coito é uma espécie de situação cinematográfica que varia redes entre um $a$ e um $a^{1}$, entrecruzando oportunamente um $b$ e um $b^{1}$ (por exemplo, a variação da noologia, incluindo, neste caso, além de outros livros, Logique du sens, onde a altura, a profundidade e a superfície são coordenadas do pensamento, ou Mille plateaux, onde o rizoma é a imagem do pensamento que se estende, não começa nem conclui, encontra-se no meio, onde as coisas ganham velocidade, crescendo, derramando-se pelas médias franjas; ou, o que é uma extensão das malhas, o entrelaçamento da noologia com os conceitos de imagem-movimento e imagemtempo do cinema). Deleuze, sem e com Guattari, procede por recorrências, mas em terrenos e ângulos bem diferentes, praticando uma espécie de perfuração em espiral: "Hume, Bergson, Proust me interessam tanto porque neles existem elementos profundos para uma nova imagem do pensamento" 29 . É, pois, Proust et les signes e muitíssimas hastes uma questão, no mínimo, de linhas e redes diversas, como respiradores lisos ou jugulares abertas, quando se ressoam páginas sem data, rompendo contratos de calendário, potencializando as condições nas quais, seja pela toca do coelho que recebe Alice, seja por Alice que nela cai, as leituras nele se permitem.

Não se faz necessário passar ao largo de contextualizações e periodizações, como as que são apresentadas por Sauvagnargues, ao examinar, com admirável perspicácia, os encontros deleuzianos e deleuze-guattarianos com as artes, identificando, num percurso providencialmente linearizado, por exemplo, a passagem do apreço pela interpretação, na primeira parte de Proust et les signes, ao apreço pela transversalização, na segunda parte do mesmo livro, e depois, finalmente, ao apreço pela experimentação, em Kafka: pour une littérature mineure, como crítica à interpretação ${ }^{30}$; diacronicamente apreendido, o ambiente alvoroçado das vibro-variabilidades conceituais, constituindo-se ou não por etapas intermediárias, não deixa de assumir as formas de verdadeiros abalos sísmicos ou hidráulicos, estando sempre carregado de potências expressivas e interrogativas, num constante estado de

\footnotetext{
${ }^{29}$ ID, "Sobre Nietzsche e a imagem do pensamento", p. 180.

${ }^{30}$ Anne Sauvagnargues (2006, p. 115-122).
} 
recomposição, intrinsecamente vulnerável a diferenciados encontros com as tradições filosóficas e não filosóficas; neste dinamismo, um conceito como o de corpo sem órgãos, por exemplo, que surge, de certa forma, ainda frouxo em Logique du sens, pode adquirir novos contornos em L'Anti-Oedipe, reaparecer transfigurado nas páginas finais de Proust et les signes, remetendo agora ao problema do narrador-herói proustiano, visto como um corpoaranha intenso, desprovido de todo o uso voluntário e organizado das faculdades, e se retorcer adiante em Mille plateaux. Por um lado, os aqui chamados vidros são aquela vibração, por assim dizer, do tipo Roussel, cujo metagrama ou metaplasmo é o do $x$ (les lettres du blanc sur les bandes du vieux billard) que se afeta (les lettres du blanc sur les bandes du vieux pillard) ou o do y (j'ai du bon tabac...) que se afeta (jade, tube, onde, aubade...), conforme tratado por Foucault em Raymond Roussel, pois neles se fazem, por contato, conjuntos declináveis de inter-relações conceituais complexantes; por outro lado, os aqui chamados coitos são aquela variação, por assim dizer, do tipo Bene, cujo teatro crítico é o da amputação ou subtração, quando ele retira alguma coisa de uma peça originária (Shakespeare) para fazer aparecer algo diferente, conforme tratado por Deleuze em "Un manifeste de moins", pois neles se fazem, por fecundação, os enredamentos das criações conceituais originárias em movimentos surpreendentemente recriadores, alérgicos a quaisquer petrificações. Tal sítio de desvios e acúmulos desenvoltos, mas também de dinâmicas travessas, tanto praticadas quanto tematizadas, não raramente torna intrincada a percepção de suas viradas; dobras, desdobras e redobras não desmentem um enunciado primário, prolongam-no por outras vias, transformando-o, às vezes, radicalmente; porém, para o problema de se poder encontrar algum estatuto ou orientação no conjunto desses deslocamentos inquietos, levando-se deles, ainda em conta, as percussões que, desabrochadas em variegadas interações, removimentam constantemente o âmbito das próprias conexões e desconexões partícipes, pronuncia-se no filósofo a autorização de pensá-lo como um sistema: "Creio na filosofia como sistema. A noção de sistema me desagrada quando ela é relacionada às coordenadas do Idêntico, do Semelhante, do Análogo. [...] Para mim, o sistema não deve estar somente em perpétua heterogeneidade, deve ser uma heterogênese" ${ }^{\text {31 }}$. Trata-se, pois, de um sistema, como diz Orlandi, tomado por "metaestabilidade rizomática" ${ }^{32}$, sistema aberto, propenso a liberar a linha, a liberar a diagonal, que se alimenta em cada caso com a determinação dos problemas

\footnotetext{
31 DRF, “Lettre-préface à Jean-Clet Martin”, p. 338.

32 Luiz Orlandi (2010, p. 129).
} 
em pauta; nele, há sons circunstancialmente martelados, enquanto dermatologia geral: a filosofia como "arte das superfícies"33, ou seja, "quando os conceitos são relacionados a circunstâncias, e não mais a essências" ${ }^{34}$, inclina-se à fórmula valeryana $o$ mais profundo é $a$ pele, já num sem oposição superfície-profundidade, descartando, com Nietzsche, qualquer ideia de profundidade enquanto entidade ideal, substituindo o modelo lógico da verdade (alétheia) pela potência do devir (poiesis), opondo-se tal superfície não à profundidade, mas àqueles empenhos e desempenhos subservientes à tirania do Significante, postos ainda no domínio brejeiro do "o que isso quer dizer?"35.

O que se desprende como função incontornável ou o que range como apelo medular na filosofia é sempre a criação conceitual: "A filosofia tem uma função que permanece perfeitamente atual, criar conceitos. [...] A única condição é que eles tenham uma necessidade, mas também uma estranheza, e eles as têm na medida em que respondem a verdadeiros problemas"36. Que a rotação das acepções correntes, no eixo da contemplação, reflexão e comunicação, não combine com o construtivismo filosófico é explicável: a filosofia é uma disciplina que não contempla, pois os conceitos não preexistem como corpos celestes, inteiramente feitos, prontos a serem mirados, numa visada das coisas mesmas; que não reflete, pois em domínios igualmente criadores, na tripartição filosofia, ciência e arte, não há carências nem inércias a serem preenchidas ou resolvidas por um pensar sobre da filosofia; que não comunica, pois a permuta de opiniões, no sentido de formação dialógica de novos universais, na ideia mesma de um acerto democrático para entronizar consensos razoáveis, reciprocidade de pares que, na verdade, "não produziu nunca o menor conceito", é toda ela inassimilável à singularidade filosófica, que visa o conceito e não o consenso ${ }^{37}$. Tal é o valor da passagem deleuziana de um paradigma filosófico corrente, que se entende funcionar por descobertas, argumentos ou debates, a um paradigma novo, mais próximo, talvez, do estético, que se entende funcionar apenas por criação: não consistindo num saber (paradigma lógicocognitivo), o valor decisivo da filosofia é semelhante àquele que certa arte moderna, ora mais, ora menos, teve como seu, que foi, em termos simultaneamente mais gerais e precisos, o de uma vocação criadora insubmissa ao feudo das coerções lógico-racionalistas. É verdade que os conceitos criados pela filosofia fomentam tarefas de contemplação, reflexão e comunicação

\footnotetext{
${ }^{33}$ C, p. 113.

${ }^{34}$ C, p. 46.

${ }^{35}$ C, p. 33.

${ }^{36} \mathrm{C}, \mathrm{p} .174$.

${ }^{37}$ QF, p. 12-13.
} 
por parte de seus estudiosos, o que nunca se confunde com uma atividade filosófica; atolados numa atenção jovial e desabotoada ou num frêmito de admiração e pasmo, eles oportunamente aconcheiam a mão atrás da orelha para não perderem sutis gravidades ou agudezas conceituais, estirando-as depois numa espécie de papel pega-mosca, sob os lampejos de uma ideia-foto que as faz grudar, para produzir toda aquela necessária tramoia didática, desembaraçando os fios, juntando as peças, evitando o luxo frívolo dos usos não pautados pela ponderação; no fundo, efeito calculado, se não disfarçados os vestígios de tal artifício ou não ocultados os andaimes de tal elegância, $o$ que por um momento veem apenas explicita o como veem, porque, ainda aqui, o caminho do meio, entre exposição e roubo, traição, humor, pode se apresentar na forma de uma "boa maneira de ler", tendo-se apenas o que passa ou não passa: "Não há nenhuma questão de dificuldade nem de compreensão: os conceitos são exatamente como sons, cores ou imagens. São intensidades que vos são ou não convenientes, que passam ou não passam. Pop'filosofia. Não há nada a compreender, nada a interpretar"38. Havendo, contudo, criação de conceitos, "a essa operação de criação sempre se chamará filosofia, ou não se distinguirá da filosofia, mesmo se lhe for dado um outro nome" ${ }^{\text {; }}$; de fato, essa peculiaridade insubstituível, cujos objetos refinados são somente os conceitos, torna irrisória qualquer projeção a respeito de seu esgotamento; ainda que se viva realmente numa época funesta, tal qual a que se macaqueia como pós-filosófica, serão disparates inúteis e penosos os desígnios de sepultá-la; não por menos, se ela puder morrer, será por gargalhadas: “Certamente, a filosofia sempre teve seus rivais, desde os 'rivais' de Platão até o bufão de Zaratustra. [...] A filosofia sente-se pequena e só diante de tais potências, mas, se chegar a morrer, pelo menos será de rir" 40 .

Aqui, a criação conceitual é a janela da filosofia, com lâminas cegas para a contemplação; vista instantaneamente, confunde o olho. É que o ideal contemplativo se empoeirou por muito tempo como o crédito bendito da filosofia, sendo conhecida a exaltação da contemplação como a única forma de vida digna ao filósofo, desde a hipotética vida puramente contemplativa dos pré-socráticos. Não sem raison d'être, a anedota platônica sobre Tales de Mileto, desdobrada frequentemente pelo âmbito da divisão entre o mundo do pensamento e o mundo da vida, fez-se forte durante séculos: por andar olhando para as estrelas, Tales cai num poço, recebendo as risadinhas da criada de Trácia; a escrava ri, é claro,

\footnotetext{
${ }^{38}$ D, p. 14.

${ }^{39} \mathrm{QF}, \mathrm{p} .15$

${ }^{40}$ C, p. 174 .
} 
por conta do ardor com que Tales procura conhecer as coisas do céu, esquecendo, todavia, as mais evidentes, debaixo de seus pés. Àquilo que, na melhor tradição platônica, constituiria o almoxarifado passivo do filósofo, a fortuna mesma da noesis, a contemplação das Ideias, ou àquilo que, na melhor tradição aristotélica, constituiria o altíssimo ideal do filósofo, a bios theoretikós, a vida contemplativa da natureza, deve-se dar, entretanto, este desarranjo: não há céu para os conceitos. Se Platão definia a filosofia como a atitude contemplativa das Ideias, se estavam nisso, intencionalmente mantidos, o seu mote e o seu foco, foi-lhe preciso criar antes o conceito de Ideia; não de forma diferente, a defesa de uma vida contemplativa exigiu previamente de Aristóteles a criação do conceito de natureza: demandaram-se atos criadores, justamente por não haver céu para os conceitos. Desde os gregos, a filosofia se colocou como uma busca da verdade, mas não por isso ela se fez contemplação, esta ideia antiga pela qual foram refogadas com sabores mascavados todas as condições pensantes; na verdade, a verdade como conceito é totalmente indeterminada, diz Deleuze com Nietzsche; não há verdade que, antes de ser verdade, não seja "a efetuação de um sentido ou a realização de um valor" ${ }^{41}$; que ela saia de um poço ou deva vir de um intransitório, do deus oculto, da coisa em si, como instância suprema ou essência preexistente que independe de uma vontade, alheia ao afã e à sutileza que deitam, por exemplo, sobre um texto ou uma ação, suas fortes pregas e elásticos, censurava-se, pelo martelo nietzschiano, com vigor: "Este modo de julgar constitui o típico preconceito pelo qual podem ser reconhecidos os metafísicos de todos os tempos [...] é a partir desta sua 'crença que eles procuram alcançar seu 'saber', alcançar algo que no fim é batizado solenemente de 'verdade "'42. Deve-se completar, adiantando ou tropeçando, pelo insigne caso Deleuze com Proust, que não se busca a verdade por algum mimo contemplativo voluntário, mas à custa de violências imprevisíveis que forçam a pensar; no amor, por exemplo, o apaixonado vive o ciúme (Swann e Odette ou o herói e Albertine); poder-se-ia dizer que ele precisa de um pensamento sobre o amor; mas são somente as pressões das circunstâncias, as agressões dos signos, não a ascese de uma vida contemplativa, que o fazem pensar, buscar a verdade; num instante, na apreensão e na interpretação dos signos, a força voraz do ciúme acaba sendo mais profunda do que o próprio sentimento de amor.

Aqui, a criação conceitual é a janela da filosofia, com lâminas surdas para a reflexão; escutada instantaneamente, confunde o ouvido. É que seria uma ilusão de carência, por parte

\footnotetext{
${ }^{41} \mathrm{NF}$, p. 69.

${ }^{42}$ Friedrich Nietzsche (2005a, p. 10).
} 
de outros domínios ou disciplinas, a espera por uma "reflexão filosófica", não menos do que uma bizarrice: matemáticos esperando os filósofos para refletirem sobre a matemática; artistas esperando os filósofos para refletirem sobre a literatura, a pintura ou o cinema. Jamais foi a necessidade de cientistas e artistas uma mediação reflexiva dos filósofos; na verdade, cômica é a ideia de que eles precisariam da filosofia para refletir sobre qualquer coisa; fizeram eles mesmos, no mínimo, as reflexões específicas de suas criações, que não eram jamais conceitos; igualmente, de forma hipotética, dizendo de outro modo, Einstein e Proust não se tornaram eventualmente filósofos por conta de "refletirem". É verdade que a reflexão, por ser um modo especial de remanejar e reorganizar os dados, também se põe como uma atividade criadora; a palavra vem do verbo latino reflectere, significando re-pensar, pensar o já pensado, um pensamento de segundo grau, sobre alguma coisa, em cima, por cima, acima; na filosofia, porém, tratar-se-ia de uma ingerência em relação à própria natureza do domínio filosófico: “Sempre que se está numa época pobre, a filosofia se refugia na reflexão 'sobre`... Se ela mesma nada cria, o que poderia fazer, senão refletir sobre? Então reflete sobre o eterno, ou sobre o histórico, mas já não consegue ela própria fazer o movimento" ${ }^{43}$. Acredita-se dar muito à filosofia fazendo dela a arte da reflexão, quer um privilégio especulativo, quer um poder exegético, mas se retira tudo dela, o seu objeto estrito ou peculiar, que são os conceitos. As tintas tradicionais, pelas quais o braço direito tatua o braço esquerdo com o desenho da reflexão, tintas destiladas por ânimos canhestros, certamente muito inadequados, que no fundo imprimem, para a filosofia, um suposto destino incontornável de falar "acima de", são ao mesmo tempo complexos de superioridade e inferioridade: o pseudoprimado de reflexão e a inferioridade de criação. A filosofia não está em estado de reflexão sobre outros domínios, mas em estado de aliança com eles, vínculos não hierárquicos nos quais tanto a ciência ou a arte não se dobra a uma posição de objeto quanto a filosofia não se eleva a uma posição de sujeito. No Proust et les signes, é aliança que não subordina o outro domínio, o que intercede, nele, como relação, que é campo já não subalterno, não submisso, não dependente; que não disputa a essência ou a coisa do outro, para um que é?, nem se ampara entre os autorizados da fortuna crítica como matéria de opinião; que nem mesmo se desloca, a despeito de sua especificidade, à “prioridade", como sustenta Machado ${ }^{44}$, em contraste, talvez, na inexatidão do lexema, com o próprio filósofo ${ }^{45}$; passa, de fato, com o outro, ambos noutro caso,

\footnotetext{
${ }^{43}$ C, p. 156.

${ }^{44}$ Roberto Machado (2010, p. 19).

${ }^{45}$ C, p. 160.
} 
fabricando-se, assim, diferentemente, na singularidade de uma orientação complicada, num encontro - no com, que não é sobre.

Aqui, a criação conceitual é a janela da filosofia, com lâminas mudas para a comunicação; pronunciada instantaneamente, confunde a boca. É que a filosofia se serve das frases de uma língua standard para exprimir algo que não é da ordem da comunicação: "O conceito é o que impede que o pensamento seja uma simples opinião, um conselho, uma discussão, uma tagarelice. Todo conceito é forçosamente um paradoxo" ${ }^{46}$. Eis então o horror dos filósofos ao jogo das proposições opositivas, discussões, controvérsias, argumentações: “Todo filósofo foge quando ouve a frase: vamos discutir um pouco. As discussões são boas para as mesas redondas, mas é sobre uma outra mesa que a filosofia joga seus dados cifrados 47 . Se o debate lhes é exigido, que por vezes ocorra de terem de mexer nos marimbondos das disputas, enfrentando, por exemplo, rodas ranzinzas de discussão, sejam as rodas povoadas por celebridades celebrando sentenças célebres, sempre ao gosto de uma totalização a ser legitimada, sejam as rodas povoadas por submissos fiéis que, aduladores, com dobradiças nas costas, diante de seus padres intelectuais, rendem reverências e fazem verdadeiros cultos (missas iniciadas, se possível, pela incrível tradição do beija-mão), fazemno com um tratamento rude, deixando o debate providencialmente subordinado ao seu construtivismo conceitual. Já Sócrates exercia o diálogo como uma forma de tornar impraticável toda a discussão, evidenciando a vocação da filosofia como o monólogo do conceito em sua automobilidade: "De fato, Sócrates tornou toda discussão impossível, tanto sob a forma curta de um agôn de questões e respostas, quanto sob a forma longa de uma rivalidade de discursos. Ele fez do amigo o amigo exclusivo do conceito, e do conceito o impiedoso monólogo que elimina, um após o outro, todos os rivais" ${ }^{48}$. As opiniões se moldam estreitamente sobre a forma da recognição, mesmo quando não disputam inúteis bagatelas: “recognição de uma qualidade na percepção (contemplação), recognição de um grupo na afecção (reflexão), recognição de um rival na possibilidade de outros grupos e outras qualidades (comunicação)" "49. É possível fornecer a essa práxis de reconhecimento do verdadeiro uma caricatura que não é outra senão a de uma ortodoxia, posta entre as regras codificadas do saber e as regras coercitivas do poder, condição em que a opinião é verdadeira

\footnotetext{
${ }^{46} \mathrm{C}$, p. 174.

${ }^{47} \mathrm{QF}$, p. 37.

${ }^{48} \mathrm{QF}$, p. 38.

${ }^{49}$ QF, p. 173.
} 
somente quando coincide com a opinião do grupo: "Vê-se bem isso em certos concursos: você deve dizer sua opinião, mas você 'ganha' (você disse a verdade) se você disse a mesma coisa que a maioria dos que participam desse concurso. A opinião, em sua essência, é vontade de maioria, e já fala em nome de uma maioria"50. Tomando-se por Minerva ou Sabedoria, o debate quer a todo custo fundar e ostentar um consenso, situação na qual, polidas as unhas e retocada a maquiagem, definem-se tribos, parentescos ou pertenças. Mas o consenso nada tem a ver com a filosofia; topa-se então com uma dificuldade que os gregos já enfrentavam, não sem esfalfamento: "encontrar, em cada caso, a instância capaz de medir um valor de verdade

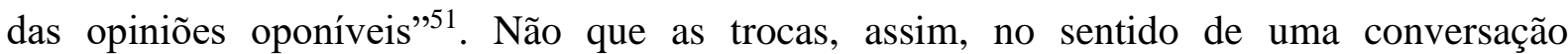
despretensiosa, devam ser proscritas, não que os intermeios devam ser suprimidos ou que o pensamento seja monocrático e autárquico (há em Deleuze todo um tema de "solidão povoada", múltipla, coletiva): os diálogos, como diz Zourabichvili, devem ser pensados "no modo da colaboração desorientadora, do tipo Deleuze e Guattari, ou então no modo de conversa livre, cujas elipses, descontinuidades e outras telescopagens podem inspirar o filósofo" ". Manifesta a filosofia deste modo uma vocação que não tem o horizonte do sentido como universal, tornando-se subordinada apenas à liberdade particularíssima de colocar o problema, conforme Deleuze já apontava outrora, deslizando rente a Bergson: “A verdadeira liberdade está em um poder de decisão, de constituição dos próprios problemas: esse poder, 'semidivino', implica tanto o esvaecimento de falsos problemas quanto o surgimento criador de verdadeiros" $"$. É a seleção de um movimento pensante, um ato arriscado, fora do reconhecível e do tranquilizador: pensamento que não vai sem perigos, sem uma fragilidade intrínseca, certa experimentação no escuro ou patologia secreta, alheando-se ou apartando-se, neste caso, de toda a política de ideias justas, chavões, clichês e abrigos diversos. Deleuze com Godard: não uma imagem justa, mas justamente uma imagem; não ideias justas, justamente ideias ${ }^{54}$.

Essa compreensão da filosofia, incrementada tardiamente em Qu'est-ce que la philosophie?, paradoxalmente não variou: "Nunca havíamos deixado de fazê-lo, e já tínhamos a resposta que não variou: a filosofia é a arte de formar, de inventar, de fabricar conceitos"55.

\footnotetext{
${ }^{50} \mathrm{QF}, \mathrm{p} .174$.

${ }^{51}$ QF, p. 96.

${ }^{52}$ François Zourabichvili (2009, p. 91).

53 B, p. 9.

${ }^{54}$ D, p. 19.

55 QF, p. 8.
} 
Fez-se, assim, invariável, em todo o percurso, sem e com Guattari, desde Empirisme et subjectivité, sendo explicitada, por exemplo, num texto de 1956, que se inicia com a seguinte frase: "Um grande filósofo é aquele que cria novos conceitos" 56 . Em tal atividade criadora, que substitui a reflexão pelo "construcionismo" e a comunicação pelo "expressionismo" possibilidades experienciais são moventes e infinitésimas, exercendo-se o pensamento no campo aberto por uma condição de consistência intensional e não extensional, muito orientado por uma ideia-cinema. Os conceitos não são proposições, a filosofia não é uma formação discursiva: as proposições são da ordem da ciência, que apresenta funções científicas em sistemas discursivos, definindo-se por sua referência a estados de coisas ou a corpos já constituídos; na filosofia, ao contrário, os conceitos entram livremente em "relações de ressonância não discursiva", não tendo outro objeto senão os seus componentes, de maneira que sua consistência significa sua autorreferência, definindo-se eles como um incorporal, no sentido estoico, sem "coordenadas espaço-temporais", apenas "ordenadas intensivas"58. Isso significa dizer, por um lado, que as proposições da ciência não são conceitos, que não existem, portanto, conceitos científicos; por outro lado, que os enunciados da filosofia não são funções, que não existem, portanto, funções filosóficas. Deleuze e Guattari recusam as noções correntes que tomam o conceito por um "universal"; na tradição, Kant assim o definiu: "A intuição é uma representação singular; o conceito, uma representação universal ou representação refletida" ${ }^{\text {59 }}$. Efetivamente, a delimitação deleuziana e deleuze-guattariana da inequívoca tarefa se firma numa distinção: "A filosofia sempre se ocupou de conceitos [...] Por muito tempo eles foram usados para determinar o que uma coisa é (essência). [...] Para nós, o conceito deve dizer o acontecimento, e não mais a essência" ${ }^{90}$. É que a filosofia se decide, na verdade, por seu estrito construtivismo, no qual o conceito "põe-se a si mesmo e põe seu objeto, ao mesmo tempo que é criado" 61 , ele "se mostra, e nada mais faz que se mostrar" ${ }^{\prime 62}$. Um livro de filosofia, segundo a ideia apresentada em Différence et répétition, deve ser um tipo particular de "romance policial" e uma espécie de "ficção científica", com os conceitos intervindo para resolver dramas noéticos,

\footnotetext{
56 ID, “Bergson, 1859-1941”, p. 33.

57 C, p. 188.

58 QF, p. 30-31.

${ }^{59}$ Immanuel Kant (2003, p. 181).

${ }^{60}$ C, p. 37.

${ }^{61} \mathrm{QF}$, p. 30.

${ }^{62} \mathrm{QF}$, p. 167.
} 
modificando-se com os próprios problemas ${ }^{63}$; no ponto, como discorre Alliez, "criar conceitos é fazer de todo conceito o conceito de seu próprio conceito: o conceito como criação, processo singular, não-universal - autoposição do conceito"64; no ponto, como discorre Lapoujade, "criar um conceito é criar a lógica que o vincula a outros conceitos" 65 . Esse construtivismo filosófico exige, enfim, que toda criação seja uma construção sobre um plano que lhe dá existência autônoma ${ }^{66}$; não à toa Nancy rotula a filosofia deleuziana de pensamento-cinema: "Trata-se de um pensamento-cinema, no sentido de uma ordem e de uma tela próprios, de um plano singular de apresentação, de construção, de deslocamentos e de dramatização dos conceitos (o próprio termo 'conceito` quer dizer isso, para Deleuze, miseen-cinéma)" ${ }^{" 67}$.

O filósofo distingue ao longo de suas obras três domínios de pensamento igualmente criadores (filosofia, ciência e arte), assim como os seus respectivos objetos de criação (conceitos, funções e sensações). O conceito é a "Ideia filosófica", a Ideia própria da filosofia, assim como a função é a Ideia da ciência e a sensação é a Ideia da arte. Nessa nitidez fotográfica, definem-se os domínios pelos elementos que efetivamente criam, na singularidade de um acontecimento, não por antecipada rotulagem ou premeditada departamentalização. Essas formas de pensamento são, sobretudo, três maneiras distintas de enfrentar o caos, traçar um plano sobre o caos, que é um virtual: "É um vazio que não é um nada, mas um virtual, contendo todas as partículas possíveis e suscitando todas as formas possíveis que surgem para desaparecer logo em seguida, sem consistência nem referência, sem consequência" ${ }^{\prime 68}$. Em outras palavras, como observa Dias, no intervalo de uma variação progressiva sobre as obras deleuzianas, o caos não é “o substrato 'ontológico' primitivo destronado pela imperante harmonia cósmica, ou o númeno hipotético submetido às regras formais da subjetividade, mas um fundo virtual imanente sempre presente, coextensivo à realidade dada, onde todas as consistências atuais se precarizam e se desfazem"69. É nesse sentido, aliás, que as opiniões, com os seus ares de fidalguia, com os seus perfis recognitivos,

\footnotetext{
${ }^{63}$ DR, p. 17-18.

${ }^{64}$ Éric Alliez (1994, p. 69).

${ }^{65}$ David Lapoujade (2015, p. 13).

${ }^{66} \mathrm{QF}, \mathrm{p} .14$.

${ }^{67}$ Jean-Luc Nancy (2000, p. 114).

${ }^{68} \mathrm{QF}, \mathrm{p} .139$.

${ }^{69}$ Sousa Dias (1995, p. 40).
} 
firmadas na vontade de uma maioria, visando unicamente a promoção de consensos, seu tic nerveux, não constituem muitas vezes pensamentos, mas uma proteção contra o caos, um guarda-chuva. Aceitar o desafio do caos, fazer-lhe frente, nele mergulhar - eis, de cada vez, a aventura do verdadeiro pensamento; todavia, são diferentes os meios e os modos dos domínios enfrentarem o caos: a filosofia traça um plano de imanência, pela ação de personagens conceituais, levando acontecimentos e conceitos ao infinito, salvando o infinito, dando-lhe consistência; a ciência traça um plano de coordenadas, pela ação de observadores parciais, definindo estados de coisas, funções ou proposições referenciais, renunciando ao infinito, ganhando referência; a arte traça um plano de composição, pela ação de figuras estéticas, carregando monumentos e sensações compostas, criando um finito que restitui o infinito $^{70}$. A particularidade decisiva de cada domínio exige dizer, naquilo que por vezes se coloca como ocorrência instigante, que nem mesmo a arte abstrata e a arte conceitual, quando são tentativas de mesclar arte e filosofia, substituem a sensação pelo conceito: a arte abstrata procura somente refinar a sensação, desmaterializá-la - assim, "não mais uma sensação do mar ou da árvore, mas uma sensação do conceito de mar ou do conceito de árvore"; a arte conceitual, por sua vez, procura somente uma desmaterialização inversa, por generalização, "para que tudo tome aí um valor de sensação reprodutível até o infinito", o que, no fundo, pode não garantir nem mesmo a sensação, pois já está dependente, em cada caso, da simples opinião de um espectador que a define como arte ou não ${ }^{71}$.

Preserve-se que os três domínios de pensamento, gratinados com os ingredientes que lhes são específicos, têm validades próprias, imperturbáveis: "Pensar é pensar por conceitos, ou então por funções, ou ainda por sensações, e um desses pensamentos não é melhor que um outro, ou mais plenamente, mais completamente, mais sinteticamente 'pensado""72. A arte em geral não pensa mais nem menos do que a filosofia, apenas pensa diferentemente, por blocos de sensações (perceptos e afectos), ao invés de conceitos; deve ser compreendida a obra de arte como um "ser de sensação": o artista inventa algo que o supera e, num sentido decisivo, independe de seus dispositivos operacionais (familiaridade da memória, da inteligência, do reconhecimento), como uma transformação de percepções em perceptos e de afecções em afectos. As sensações valem por si mesmas, não se domesticando pelo âmbito vivencial do artista ou pelo âmbito vivencial dos fruidores da arte; é possível dizer, para destituir alguma

\footnotetext{
${ }^{70}$ QF, p. 233.

${ }^{71} \mathrm{QF}$, p. 234.

72 QF, p. 233.
} 
panaceia recognitiva, que as sensações existem na ausência do homem; no fundo, mesmo "o homem" fixado numa tela ou num texto é também um composto de perceptos e afectos. Não se deve, pois, confundir perceptos com percepções nem afectos com afecções ou sentimentos: “Os perceptos não mais são percepções, são independentes do estado daqueles que os experimentam; os afectos não são mais sentimentos ou afecções, transbordam a força daqueles que são atravessados por eles"73. Nos escritores, o material singular se constitui por palavras, pela sintaxe que se ergue em suas obras, um "material complexo"; mas o que se conserva, de direito, não é o material, que constitui somente a condição de fato; o que se conserva são perceptos e afectos, as sensações, que são potências; se o material durasse no máximo os poucos segundos de uma brisa veloz, ainda assim se daria às sensações o poder de existirem na eternidade que coexiste com a curtíssima duração. Para o escritor, trata-se de extrair um puro ser de sensação, arrancar o percepto das percepções, arrancar o afecto das afecções, como passagem de um estado a outro - o que varia, em cada autor, por procedimentos diferentes. Neste ponto, mesmo em Proust, o ato do monumento artístico não é a memória, mas a fabulação, que "não consiste em imaginar nem em projetar um eu"74, atingindo algo que ultrapassa completamente os estados perceptivos do vivido. É que, em qualquer caso, não se escreve como uma comemoração do passado, das percepções vividas ou das lembranças da infância; escreve-se por "blocos de infância", sensações que são devirescriança do presente: "Só se atinge o percepto ou o afecto como seres autônomos e suficientes, que não devem mais nada àqueles que os experimentam ou os experimentaram: Combray, como jamais foi vivido, como não é nem será vivido, Combray como catedral ou monumento"75. Em suma, a arte não corresponde ao que se acha indelevelmente lavado e lustrado pela recognição; algo só é uma obra de arte se "guarda vazios suficientes para permitir que neles saltem cavalos"76.

As relações entre filosofia e não filosofia (ciência e arte) é uma contaminação pluridisciplinar que, por ideia-foto e ideia-cinema, não desvanece a peculiaridade da filosofia: "Os três pensamentos se cruzam, se entrelaçam, mas sem síntese nem identificação. [...] Um rico tecido de correspondências pode estabelecer-se entre os planos"77. As coisas se fazem pela interferência de muitas práticas: os conceitos filosóficos encontram intercessores nas

\footnotetext{
${ }^{73}$ QF, p. 193-194.

${ }^{74}$ CC, "A literatura e a vida", p. 14.

75 QF, p. 198.

$76 \mathrm{QF}$, p. 196.

${ }^{77} \mathrm{QF}$, p. 234.
} 
funções científicas ou nas sensações artísticas, assim como eles próprios podem servir à ciência ou à arte; necessidade é de cada domínio, em função de uma evolução própria, interceder e ser intercedido, cruzar e ser cruzado, relançar e ser relançado. É possível exemplificar, num pequeno passo, certos ecos ou ressonâncias: uma questão de matemática (por exemplo, o chamado "espaço riemanniano") ou uma questão de física (por exemplo, a chamada "transformação do padeiro", com a física probabilística de Prigogine) pode ser verificada no cinema de um Bresson ou de um Resnais; para Deleuze, não se trata de afirmar que Bresson imita Riemann ou de afirmar que Resnais imita Prigogine, mas de constatar que existem semelhanças extraordinárias entre criadores científicos de funções e criadores cinematográficos de imagens ${ }^{78}$. As disciplinas não se definem em diferenças sem constituírem também cruzamentos, por correntes recíprocas de frequência, sem perda de azeite, independentes de qualquer primado: "Nesse sentido, é preciso considerar a filosofia, a arte e a ciência como espécies de linhas melódicas estrangeiras umas às outras e que não cessam de interferir entre si" ${ }^{\text {79. }}$. Nos encontros com os domínios não filosóficos, a exclusividade dos conceitos assegura à filosofia uma especificidade, embora não lhe outorgue nenhum privilégio ou proeminência, colocando-a, ao contrário, rente à ciência e à arte, que são "outros modos de ideação que não têm de passar por conceitos" ${ }^{" 80}$; de pronto, se a filosofia está em conexão com outros domínios, nunca é por lhes seguir o movimento, fazer a mesma coisa, tampouco por lhes fornecer explicações reveladoras, mas por encontrar neles algo que a faz vibrar enquanto atividade conceitual. O essencial é que, a cada instante, os intercessores relançam o ofício filosófico, suscitam ou pedem conceitos, como no caso do cinema: "Uma teoria do cinema não é 'sobre' o cinema, mas sobre os conceitos que o cinema suscita" 81 . Aqui, aliás, as interposições permitem, ainda que os dois domínios tenham ferramentas específicas, uma extensão das malhas: “A relação cinema-filosofia é a relação da imagem com o conceito. Mas no próprio conceito existe uma relação com a imagem, e na imagem uma relação com o conceito: por exemplo, o cinema sempre quis construir uma imagem do pensamento, dos mecanismos do pensamento" $" 82$. Pode-se generalizar, por comodidade, mas não sem distinguir os problemas de interferência entre planos que se juntam no cérebro (interferências

\footnotetext{
${ }^{78}$ C, p. $158-160$.

${ }^{79} \mathrm{C}$, p. 160.

${ }^{80} \mathrm{QF}$, p. 15.

${ }^{81}$ IT, p. 331.

82 C, p. 87.
} 
extrínsecas, intrínsecas ou ilocalizáveis) ${ }^{83}$, que para Deleuze e Deleuze-Guattari tudo se movimenta numa complexidade de encontros interexpressivos; nas relações com a arte, a modalidade prática da filosofia é sempre a criação de conceitos, resolvendo pelo seu lado e com os seus próprios meios os problemas afins que participam no outro domínio - e, no entanto, não será abusivo nem impróprio afirmar que a filosofia se enche de sensações: "Os conceitos são inseparáveis dos afectos, ou seja, dos efeitos potentes que têm sobre nossa vida, e dos perceptos, ou seja, de novas maneiras de ver ou de perceber que eles nos inspiram" 84 . Eis aí a condição de o pensamento conceitual se fazer numa zona de pulsações transrelacionais, entre franjas articuladas e circuitos ressonantes, nas modulações do filosófico e do não filosófico, não redundando em policiamentos de uma linha sobre a outra ${ }^{85}$.

Nunca é diferente o caso particular com a literatura, que constantemente se insere nessas modulações - seja sob a forma explícita de livros nos quais uma literatura específica dinamiza todo um tecido conceitual (em Proust et les signes, Présentation de Sacher-Masoch ou Kafka: pour une littérature mineure), seja sob a forma genérica de trechos nos quais literaturas várias, participando em inteireza ou não dos índices problematizados, dinamizam vez a vez numerosas feições conceituais (em Différence et répétition, Logique du sens, Mille plateaux, Dialogues ou Critique et clinique). Quando se vê, contudo, no conjunto da obra, que misturadas desigualmente estão as transrelações, retorcendo-se elas mesmas, assim, de mil e uma maneiras, torna-se insuficiente qualquer tentação de superestimar quais são os livros ou trechos mais relacionados com a literatura; até mesmo mapeamentos ou inventários bem direcionados naufragam nos embaraços das linhas e redes diversas que, enquanto desenho de pensamento, distribuem-se por toda parte, embora se possa identificar, é claro, num ou noutro escrito, os quadros especiais de problemas nos quais as modulações entre filosofia e literatura se compõem; não por mais nem por menos, a prudência comumente exige que os leitores dessa filosofia não desacompanhem o bailar ziguezagueante das ondas. Deleuze é vampiro, para além dos procedimentos de colagem, sugando o sangue de muitos pensadores, numa lufada de ar (imagem cômica); não se trata de influências sofridas, mas de insuflações e enxames, criando conceitos através de um sistema de vínculos entre noções oriundas ou

\footnotetext{
83 QF, p. 255-257.

${ }^{84}$ DRF, "Lettre à Uno: comment nous avons travaillé à deux", p. 219

85 C, p. 160.
} 
extraídas das tradições filosóficas (por exemplo, Espinosa, Nietzsche e Bergson) e conceitos suscitados ou disparados por diversas literaturas. As vozes dos literatos são fluxos que constantemente correm ou escorrem no próprio fluxo filosófico, que de quando em quando se desvia e se constrói nos desvios, criando muitas vezes encadeamentos inusitados, como acontece, por exemplo, não raramente, em L'Anti-Oedipe; no ponto, aquilo que poderia ser entendido como meras citações ou referências literárias não tem ali, de forma alguma, este estatuto. Ocorre, assim, com efeito, a complication deleuziana a qual também se refere Micolet, em sua "Introduction" à coletânea Deleuze et les écrivains, cujas afirmações se completam num passo a passo: em primeiro lugar, "há na obra de Deleuze um fenômeno característico de complicação"; em segundo lugar, "a complicação pode ser compreendida como a complicação de termos diferentes, que entram em relação em vez de se excluírem ou de se justaporem"; em terceiro lugar, "fillosofia e literatura estão implicadas reciprocamente uma na outra, voltadas uma à outra, cada termo complicando o outro" ${ }^{\text {" }}$. Desnecessário é conjecturar se Micolet pretende revestir tal âmbito relacional com todas as tramas dadas pelo próprio conceito de complicação em Deleuze, exprimindo, assim, tanto um estado complicado, o das diferenças envolvidas ou implicadas umas nas outras, correspondendo a um "encontro disjuntivo", avesso à mera fusão, quanto a operação de síntese dos movimentos inversos, do virtual ao atual (explicação, desenvolvimento) e do atual ao virtual (envolvimento, implicação), como discorre Zourabichvili ${ }^{87}$; para o efeito premente, basta afirmar que a atmosfera contida em tal estado complicado opera em todos os extratos relacionais, seja num Différence et répétition, seja num Mille plateaux, tratando-se de uma complexa tecedura envolvendo o domínio dos conceitos e das sensações. Chame-se de complicação deleuze-proustiana o que se tem em Proust et les signes, de complicação deleuze-masochiana o que se tem em Présentation de Sacher-Masoch e de complicação deleuze-guattari-kafkiana o que se tem em Kafka: pour une littérature mineure: são alianças do tipo ciclista e bicicleta que põem em correspondência os objetos notáveis de cada domínio, filosofia e literatura, por co-implicação ou co-funcionamento.

O ponto nevrálgico é que algo em estado de arte fomenta algo em estado de conceito ou que uma frequência própria de um primeiro domínio promove uma frequência própria de um segundo domínio; nas palavras de Dias, a questão é surpreender na literatura o seu paradoxo

\footnotetext{
${ }^{86}$ Hervé Micolet (2007, p. 7).

${ }^{87}$ François Zourabichvili (2009, p. 28-30).
} 
constituinte: uma vocação não literária, uma finalidade extralinguística, nos meandros da linguagem literária ${ }^{88}$. Critique et clinique, coletânea que se inspira no problema de escrever, está carregado dessa complicação entre filosofia e literatura, operando conceitualmente: agramaticalidade, menor, linha de fuga etc. Notável é nesse livro o ambiente fotográfico, a explicação do que constitui, na literatura, a condição de fato, o "material complexo", certas peculiaridades da linguagem literária, especialmente quando correspondem a um uso intensivo e menor da língua (embalo de escavações, tensões, variações), ultrapassando um uso extensivo e maior (embalo de imagens, símbolos, sentidos), como percebe Almeida ${ }^{89}$. A questão dos procedimentos de linguagem, que em Logique $d u$ sens se pautava mais na dimensão vocabular (palavras-valise de Carroll, palavras-sopro de Artaud), ganha relevo nos ensaios de Critique et clinique em termos de sintaxe, tendo-se agora que "não há criação de palavras, não há neologismos que valham fora dos efeitos de sintaxe nos quais se desenvolvem" $" 90$. Transitando diferentemente em escritores como Melville, Whitman, Carroll, Roussel, Beckett e Luca, o filósofo considera o modo como um escritor decompõe, desarticula ou desorganiza a língua materna: os não-lugares que uma palavra ocupa, o desequilíbrio de intensidades e relações, os d-efeitos sintáticos, as disritmias da língua eficiências intrínsecas de certa assintaxia ou agramaticalidade, mais do que eficiências léxicas. A grandeza de um estilo está na audácia, na estrangeirice dos modos e aplicações, como se pode lembrar Proust em Contre Sainte-Beuve, defendendo que "os belos livros são escritos numa espécie de língua estrangeira"91, ou Chklovski em "A arte como procedimento", por uma recuperação aristotélica: "Segundo Aristóteles, a língua poética deve ter um caráter estranho, surpreendente; na prática, é frequentemente uma língua estrangeira" 92 . O que a literatura produz na língua já aparece melhor, diz Deleuze: "ela traça aí precisamente uma espécie de língua estrangeira, que não é uma outra língua, nem um dialeto regional descoberto, mas um devir-outro da língua, uma minoração dessa língua maior, um delírio que a arrasta, uma linha de feitiçaria que foge ao sistema dominante" 93 . Cada escritor está obrigado a criar a sua língua; porém, o grande escritor, pelo uso intensivo e menor, cria verdadeiramente uma língua de delírio: "Ele traz à luz novas potências

\footnotetext{
88 Sousa Dias (2007, p. 278).

89 Julia Almeida (2003, p. 109-111).

${ }^{90} \mathrm{CC}$, “A literatura e a vida", p. 16.

91 Marcel Proust (1988, p. 141).

92 Vitor Chklovski (1976, p. 54).

${ }^{93} \mathrm{CC}$, "A literatura e a vida", p. 16.
} 
gramaticais ou sintáticas. Arrasta a língua para fora de seus sulcos costumeiros, leva-a a delirar"94. Eis o caso da fórmula "I would prefer not to", na novela Bartleby, o escrivão, de Melville: Bartleby vai trabalhar num escritório de advocacia, tendo a tarefa de copiar documentos; paradoxalmente, nega-se ao mínimo trabalho, repetindo, em diversas situações, a frase Eu preferiria não; do ponto de vista dos pressupostos, a recusa contínua demanda a renúncia da função de copista, a única que justificaria a sua presença no escritório; quando o chefe, porém, quer lhe arranjar outro emprego, sua resposta é a mesma frase devastadora; Bartleby termina, enfim, na prisão, onde morre, sem jamais abdicar da surrada frase. Esse mecanismo de palavras, "I would prefer not to", compõe, na verdade, uma língua estrangeira na própria língua, desequilibrando o padrão linguístico: “sem dúvida, ela é gramaticalmente correta, sintaticamente correta, mas seu término abrupto, not to, que deixa indeterminado o que ela rechaça, lhe confere um caráter radical, uma espécie de função-limite. [...] A esse respeito tem a mesma força, o mesmo papel que uma fórmula agramatical" ${ }^{\prime 25}$. As anomalias ou as extravagâncias da "fórmula" geram irretocáveis conflitos lógicos: o chefe repousa numa "lógica dos pressupostos", segundo a qual o patrão espera ser obedecido, enquanto Bartleby inventa uma "lógica da preferência", que é suficiente para minar os pressupostos, eliminando impiedosamente tanto a idealidade do preferível quanto a idealidade do não preferido; há desta maneira uma zona de indiscernibilidade, de indeterminação ou de indistinção, um vazio na linguagem; é que Bartlebly, sabendo talvez alguma coisa inexprimível ou vivendo alguma coisa insondável, traça uma linha de fuga ou uma desterritorialização nos mecanismos dominantes da língua, cria uma espécie de lógica alógica - nas intensidades do “indizível”, como aponta Pelbart ${ }^{96}$.

Esses escritores pensam com pinças vibráteis ou convulsivas, escrevem uma língua bastarda, um puro som, um puro grito; a língua estrangeira na literatura é volta e meia uma "gagueira", embaraço em descomedimento perpétuo; de maneiras muito diferentes, num Luca, o poeta romeno, ou num Beckett, o poeta irlandês, o escritor se torna gago da língua: “ele faz gaguejar a língua enquanto tal"97. A gagueira é o desequilíbrio que define um estilo (ou um não-estilo), como variação de variáveis, uma sintaxe desviante; a língua se põe em movimento, desliza e varia, como no poema "Passionnément", de Luca, a fim de desprender

\footnotetext{
${ }^{94}$ CC, "Prólogo", p. 9.

95 CC, "Bartleby, ou a fórmula", p. 91.

96 Peter Pál Pelbart (2000a, p. 20).

${ }^{97}$ CC, "Gaguejou...", p. 138.
} 
um bloco sonoro último depois de séries gaguejantes, ou faz crescer uma frase pelo meio, como no poema "Comment dire", de Beckett, quando se rompe a superfície das palavras, partícula a partícula, pela introdução de um segmento ${ }^{98}$. Essa língua que resiste à própria língua, cujos elementos, como multiplicidades, encenam, pela proliferação, um desenho rizomático, diz respeito a um processo de criar um povo que falta: “É um povo menor, eternamente menor, tomado num devir-revolucionário. Talvez ele só exista nos átomos do escritor, povo bastardo, inferior, dominado, sempre em devir, sempre inacabado" 99 . O escritor nunca escreve para se tornar escritor, mas para outra coisa que se passa na escrita (e a ultrapassa), que a faz mais do que escrita, para ir a alguma outra coisa - como é possível dizer, assim: "quero ser poeta, e trabalho para me tornar vidente" (Rimbaud, na carta a Izambard $)^{100}$. Certamente, os procedimentos de linguagem são apenas a condição que faz outras coisas funcionarem; equivocada é a ideia de uma literatura que, hipnotizada em ornamentações e tecnicismos verbais, não se lança às sensações; a literatura não se reduz à linguagem, tampouco ao procedimento em si; eis uma afirmação importante de Deleuze a esse respeito: "O procedimento impele a linguagem a um limite, mas nem por isso o transpõe. Ele devasta as designações, as significações, as traduções, mas para que a linguagem afronte enfim, do outro lado de seu limite, as figuras de uma vida desconhecida e de um saber esotérico"101. Em outras palavras, procedimentos intensivos, aquém ou além dos jogos de semelhança e representação, levam a linguagem a um limite assintático ou agramatical que devasta as designações ("é isto" ou "não é isto") e as significações ("isto implica aquilo" ou “isto, logo aquilo"); no ponto, o delírio da língua é a condição genética de uma "vida desconhecida", não reconhecível, inapreensível ao uso laboratorial da linguagem, com forças não representáveis, uma vida acessível apenas a um "saber esotérico", que subverte o consenso e escapa ao senso comum. Do outro lado de seu limite, quando a linguagem, por sair de seus sulcos costumeiros, "se comunica com seu próprio fora" 102 - o fora como um fora $d a$ linguagem ("seu próprio fora"), não um fora à linguagem -, produzem-se visões e audições não linguageiras, já não pertencentes a nenhuma língua: "Essas visões não são fantasmas, mas verdadeiras Ideias que o escritor vê e ouve nos interstícios da linguagem, nos desvios de

\footnotetext{
98 CC, “Gaguejou...”, p. 142-143.

${ }^{99} \mathrm{CC}$, “A literatura e a vida", p. 15.

${ }^{100}$ Arthur Rimbaud ([13 mai 1871] 2014, p. 30).

${ }^{101}$ CC, "Louis Wolfson, ou o procedimento", p. 33.

${ }^{102}$ CC, "Prólogo", p. 9.
} 
linguagem. [...] Elas não estão fora da linguagem, são o seu fora" ${ }^{103}$. É que, para Deleuze, o problema de escrever é inseparável de um problema de ver e ouvir; Machado assim o explica: “Uma linguagem levada ao extremo limite, elevada à potência do indizível, torna possíveis visões e audições libertas do empírico, visões e audições superiores, puras, capazes de ver o invisível e ouvir o inaudível, tornando o escritor um vidente (voyant) e um ouvinte (entendant), alguém que vê e ouve algo grande demais, forte demais, excessivo"104.

Esse pensamento em complicação ou com a literatura não é exatamente um pensamento sobre a literatura, mas sobre os conceitos que a literatura suscita; trata-se sempre de esculpir com novos cinzéis quaisquer pensamentos, conforme o filósofo define numa carta a Villani: combater um erro (função polêmica), reparar um esquecimento (função inventiva) e criar um novo conceito (função criativa) ${ }^{105}$. Proust et les signes é, desta forma, desenho de pensamento com Proust, cuja Recherche é assimilada como o relato de um aprendizado; o erro combatido é a concepção da obra como um livro de memórias, não projetado para o futuro; o esquecimento reparado é o sistema dos signos proustianos, cuja pluralidade implica tanto o processo de aprendizado quanto a revelação final; o novo conceito criado é a coexistência de três tempos (tempo que se perde, tempo perdido e tempo que se redescobre), encontrando cada um a sua verdade no tempo original absoluto da arte (tempo redescoberto). Mas o livro, afetado por vidros e coitos, possui duas partes bem diferentes, o que deliberadamente reposiciona, em movimentos, o tríplice propósito de erro, esquecimento e conceito. Présentation de Sacher-Masoch é, desta forma, desenho de pensamento com Masoch e Sade, cujos nomes designam masoquismo e sadismo; o erro combatido é a pseudounidade do sadomasoquismo, que reduz Masoch a um estado quase secundário; o esquecimento reparado é a importância do contrato masoquista, tema não acessório; o novo conceito criado é a dissociação do sadismo e do masoquismo: “'Sadomasoquismo' é um desses nomes mal fabricados, um monstro semiológico" ${ }^{106}$. As especificidades clínicas das duas perversões não são separáveis das especificidades críticas das duas literaturas, signos de Masoch e signos de Sade, afetando-se mutuamente a crítica (no sentido literário) e a clínica (no sentido médico): “A obra de arte é portadora de sintomas [...] Neste sentido, tanto quanto o melhor médico, o

\footnotetext{
${ }^{103}$ CC, "A literatura e a vida", p. 16.

104 Roberto Machado (2010, p. 212).

105 Arnaud Villani (1999, p. 56).

106 SM, p. 130.
} 
artista e o escritor podem ser grandes sintomatologistas, como o foram Sade e Masoch" 107 . Quando são considerados os mecanismos estéticos e patológicos, os sintomas se tornam irredutíveis: enquanto o masoquista precisa de contratos (alianças), o sádico precisa de instituições (possessões); pelas alianças contratadas, o masoquista garante a sua relação com o parceiro, conferindo-lhe direitos por um tempo determinado; pelas possessões instituídas, o sádico rompe com quaisquer possibilidades contratuais, ultrapassando-as em todos os sentidos. Kafka: pour une littérature mineure é, desta forma, desenho de pensamento com Kafka; o erro combatido, na contramão de certas obsessões analíticas ou exegéticas, erro designado desde a primeira página, é justamente o regime de interpretação ou significância, tendo-se que as entradas múltiplas dos textos kafkianos não permitem aos leitores atrevimentos em torno de um significado solene; o esquecimento reparado é a obra kafkiana que se propõe apenas à experimentação, "protocolos de experiência", testando-se, nisto, digase, os vincos do próprio pensamento criador que com Kafka a cada instante se desdobra; alguns dos novos conceitos criados são rizoma, literatura menor e agenciamento, remodelando, assim, por vidros e coitos, certas formulações apresentadas em obras anteriores e posteriores. Abarcando, por exemplo, as três características das "literaturas menores" (desterritorialização da língua, ligação do individual com o imediato político e agenciamento coletivo de enunciação), opõem-se, qualitativamente, maioria, implicando uma constante ou um padrão, e minoria, implicando um desviar do modelo estandardizado; no que se refere aos procedimentos, não se tem dois tipos de línguas, mas dois tratamentos distintos de uma mesma língua; prontamente, um uso menor da língua significa inventar linhas de fuga na própria língua, fazê-la escapar do regime vigente: "Uma literatura menor não pertence a uma língua menor, mas, antes, à língua que uma minoria constrói numa língua maior”108.

No entanto, sumários desse tipo, como que retirando de um alimento, à luz bruxuleante de uma vela, o último resquício de sabor, não por menos muito antes que se conte uma provável centésima contração da mandíbula, decerto não comportam todas as nuanças dinamizadas na complicação com as três literaturas agora citadas, servindo aqui apenas como supostos painéis de funções polêmicas, inventivas e criativas; em pétrea solidez, tais painéis podem mimetizar os sacolejos que se apontam cá ou lá em destaque, ensaiando-se, portanto, quando se quer alguma mastigação sintética, num propósito fotográfico, mas sem abarcarem

107 ID, "Mística e masoquismo", p. 172.

108 K, p. 38. 
jamais todos os movimentos viscerais que os compõem; é que, se não raras vezes um pensamento não chega à segunda onda, que é o seu mundo em processo, em movimento, em cinema, muito mais burlesco do sumário será o tino megalo-nanico de bestializá-lo, primitivizá-lo ou infantilizá-lo numa estátua protocolar (tal livro é sobre $x$, no qual se defende a tese y). Situe-se, evidentemente, o caso de Proust et les signes: erro, esquecimento e conceito, sob o ponto de vista dos maxilares reflexivos que sobre eles podem se debruçar, nunca engessam o que se ricocheteia enquanto fluxos polivalentes; nas duas partes, o maquinismo de peças, o móbile, implica vibrações e variações conceituais; vistas em conjunto, elas têm a envergadura de uma escultura movente, rangendo braços e articulações, com bélicas metamorfoses: não se passa pela primeira, sem as agitações que, com outros livros, podem traçar, por exemplo, um composto conceitual signo-pensamento; não se passa pela segunda, sem as agitações que, com outros livros, podem traçar, por exemplo, um composto conceitual antilogos-transversalidade. Como diz Sauvagnargues, as três versões que compõem as duas partes de Proust et les signes transformam radicalmente o enunciado inicial (enunciado que, todavia, não é negado nas versões subsequentes, mas prolongado) ${ }^{109}$; a questão da emissão e da interpretação dos signos se alonga na questão da produção e da multiplicação dos signos, sem que uma questão precise necessariamente da outra para funcionar. Eis também o que diz Godino sobre Proust et les signes: "Este ensaio encontra-se numa espécie de encruzilhada, não há só um conceito novo; em cada momento, descobre-se que o pensamento deleuziano está todo ali, talvez em germe, talvez em sonho" ${ }^{110}$. Da família das moscas insistentes, o livro tem uma vocação de movimento, bracejando ou perneando, não constituindo um conjunto definitivo, produzindo de cada vez um novo charme de asas; em vão se procuraria nele as banalidades de uma unidade ou totalidade lógica e orgânica, em que cada parte determina o todo e o todo determina as partes; no máximo, num esforço de análise, pode-se encontrar algum mapa frouxo de conectividade extrauterina (retomadas ou antecipações), como sugerem Ferraris e De Agostini: a primeira parte, "Os signos", estaria articulando uma série de conceitos que se apresentam em Différence et répétition, enquanto que a segunda, "A máquina literária”, estaria colhendo a influência direta de Logique du sens, sem nunca estarem aferrolhadas, porém, as conexões com outros livros, como os deleuze-

\footnotetext{
109 Anne Sauvagnargues (2006, p. 16).

${ }^{110}$ Ana Godino (2007, p. 71).
} 
guattarianos L'Anti-Oedipe, Kafka: pour une littérature mineure e Mille plateaux ${ }^{111}$. O livro grita, assim, na verdade, entre compostos conceituais, como mosca esvoaçante.

111 Maurizio Ferraris e Daniela De Agostini (1978, p. 66-67). 


\section{DOIS}

Na primeira parte, "Os signos", publicada em 1964, a incidência é a obra de Proust como um sistema pluralista de signos: "A Recherche se apresenta como a exploração dos diferentes mundos dos signos, que se organizam em círculos e se sobrepõem em certos pontos"112. Du côté de chez Swann, À l'ombre des jeunes filles en fleurs, Le côté de Guermantes, Sodome et Gomorrhe, La prisonnière, Albertine disparue (ou La fugitive) e Le temps retrouvé são o "relato de um aprendizado" (não exatamente nos termos, por exemplo, de Barthes, que assim também os define, ao salientar aspectos de "hipersemanticidade" sediados nos nomes próprios ${ }^{113}$ ); mais precisamente, os sete volumes compõem o relato do aprendizado dos signos por parte de um homem de letras ${ }^{114}$, o narrador-herói, que é um clínico, intérprete, decifrador. É a complicação deleuze-proustiana, todavia, não conceber os signos solenemente nos entremeios da recognição ou sob flautas semióticas e semiológicas de inspiração linguística: eles têm o estatuto paradoxal do não reconhecido e, porém, encontrado; envolvem uma lógica da sensação que promove uma lógica do sentido, feito guias fugidios ou fugazes, quando exercem sobre o pensamento uma violência, forçando-o a pensar. Por que essa alegria desusada e poderosa? - eis o que, como exemplo, é engendrado por um signo sensível, a bater de chapa, cheio de densas auroras, depois que o chá amoleceu na boca a madeleine. No acaso dos encontros, há sempre a pressão das coações, tendo-se que pensar não é um ato natural ao pensamento. A obra está voltada ao futuro e aos progressos do aprendizado, o que suprime, desconcertando, assim, gerações de exegetas, toda a ideia tradicional de um livro de memórias, posição deleuziana reafirmada em Pourparlers: "Em Proust não é a memória que é explorada, são todas as espécies de signos, dos quais é preciso descobrir a natureza de acordo com os meios, o modo de emissão, a matéria, o regime" ${ }^{115}$. As experiências que a cadenciam, não sem ortopedias mnemônicas, que são, no entanto, apenas meios ou recursos em torno de signos específicos, indicam um processo de aprendizado que tem no futuro a sua noção temporal; é que, num sentido amplo, diz o filósofo em $Q u$ 'est-ce

\footnotetext{
112 PS, p. 11 - PS(br), p. 4.

${ }^{113}$ Roland Barthes (2004).

${ }^{114}$ R-TR, p. 692.

115 C, p. 182.
} 
que la philosophie?, "a memória intervém pouco na arte (mesmo e sobretudo em Proust)""116. O caminho de Méséglise-la-Vineuse (o lado que segue pela casa de Swann) e o caminho de Guermantes, tanto opostos quanto irreconhecíveis um ao outro, cujo costume de jamais ir num mesmo dia em suas direções, tomando-se o evento nos termos da própria engenharia proustiana, fechava-os, justapostos, ainda bem longe um do outro, nos vasos cerrados e não comunicantes entre eles ${ }^{117}$, são muito mais linhas do aprendizado, os dois caminhos de uma "formação", do que fontes geográficas de lembrança. Pode-se dizer que o herói não sabe algumas coisas no início, aprende-as progressivamente, até a revelação final da arte, que se mostra como o corolário do aprendizado, reagindo sobre todos os signos, principalmente sobre aqueles que aparecem nas impressões ou qualidades sensíveis (madeleine, campanários, pedras do calçamento, guardanapo), dando-lhes o colorido de um sentido estético; o intérprete então compreende o que lhe escapara, por exemplo, no caso dos campanários de Martinville, indo agora mais além, pois nesse meio tempo o problema da Arte foi colocado. Mas há todo um movimento de revelações e decepções que dá ritmo a Recherche: o que se revela em determinado campo de signos é acompanhado por vezes de regressões em outros campos, numa errância interminável, tornando-se descoberta frágil ou fracassada enquanto a revelação artística ainda não sistematizou o conjunto.

Reside na obra proustiana um longo e retorcido processo de experiências que, no final, é coroado ou interrompido pela iluminação artística, transformando, retrospectivamente, toda a narrativa em história invisível de uma vocação; tal sequência exige, contudo, considerar o possante problema do movimento e da fixação que nela se entrelaçam: um privilégio cinematográfico do processo pode retirar da iluminação final a chave do processo, assim como um privilégio fotográfico da iluminação final pode retirar do processo a chave da iluminação. Esse problema dos privilégios é resolvido conceitualmente na complicação deleuze-proustiana pela conjugação de dois pontos de vista que envolvem o sistema dos signos: ao mesmo tempo, processo de aprendizado e revelação final. Reside na obra proustiana a movediça questão das vozes narrativas, mesclando-se na voz alta de um herói, que conta diversas aventuras mundanas, amorosas, sensíveis e artísticas, e na voz baixa de um narrador, que embalsama a do herói, como que mais habilidoso e adiantado na consciência, responsável pelas prolépses que, muitíssimas vezes, aparecem sob a forma de um veremos

\footnotetext{
116 QF, p. 198.

117 R-CS, p. 117-118.
} 
depois, ou um como veremos na terceira parte desta obra, ou um veremos mais tarde, até se sobressair nos momentos finais de Le temps retrouvé, com a estupenda dissertação sobre a arte, cujo caráter programático não raramente fez e faz os intérpretes proustianos superestimarem a homonímia entre o autor da Recherche, entidade empírica, e o narrador da Recherche, entidade fictícia. Essa distinção entre herói e narrador não é seguida pela complicação deleuze-proustiana, que utiliza conceitual e indistintamente tanto a palavra "narrador" quanto a palavra "herói", costurando depois, na segunda parte de Proust et les signes, uma noção de narrador-herói que não funciona como sujeito, mas como um enorme corpo sem órgãos. Residem na obra proustiana complexas superposições de planos, como a que aparece em La prisonnière, quando o aprendizado tem como subtexto a execução de uma peça musical de Vinteuil na recepção dos Verdurin ${ }^{118}$, e numerosos efeitos puzzle de retorces asfixiados em si mesmos, não importa se na predominância de cenas ou sumários, por meio daquelas frases torrenciais que Benjamin um dia chamou de "um Nilo da linguagem"119, com lentidões e floreios diversos, nós no encadeamento, digressões, lacunas, estacionamentos meramente cinematográficos, não já cavalgando o coiote da precipitação, mas o caramujo da tardança, narrativa feito bicho preguiça - refrigerantes e pipocas, não se sabe, ao leitor. Esse dinamismo de superposições e efeitos, combinado a outras questões, suscita inalienáveis transcriações conceituais na complicação deleuze-proustiana, desaguando numa noção de estilo que, por sua vez, sem se limitar ao âmbito da linguagem, assume pelo menos duas faces distantes: na primeira, o estilo está ligado ao signo artístico, como estilo-essência, espiritualização da matéria artística; na segunda, ele é um não-estilo (ou um estilo antilogos), pois se confundindo com o interpretar puro, sendo explicativo através das imagens mais surpreendentes, não sugestivo nem reflexivo. Reside na obra proustiana a inevitável experiência do tempo (ou dos tempos), como um núcleo transversal, pelos laços enviesados entre as numerosas páginas que separam o quarto de Combray, em Du côté de chez Swann, onde o menino espera o beijo da mãe, e a biblioteca do palácio de Guermantes, em Le temps retrouvé, onde o homem recebe uma iluminação decisiva, não sem ver por ali o desfile da morte, o espantoso espetáculo que, por conta da passagem do tempo, apresenta-se em rostos surpreendentemente enrugados, envelhecidos. Essa experiência do tempo, na complicação deleuze-proustiana, corresponde conceitualmente ao aprendizado dos signos, que implica, em

\footnotetext{
118 R-AP, p. 187-197.

119 Walter Benjamin (1994, p. 36).
} 
seu aspecto decisivo, uma formulação signo-pensamento. Tudo está impulsionado por três ideias que se decidem numa dinâmica de encontros e sensações: os signos são signos somente quando constituem um problema para o pensamento (ideia do encontro intensivo); não se trata de reconhecer na experiência algo que o pensamento sabe (ideia do não-reconhecível); o aprendiz desconhece a condição pela qual ele pode ser afetado (ideia do acaso).

Qual é a busca? - é o que se pode perguntar, tomando as coisas não apenas pelo extrato do paratexte que a nomina. A Recherche, embora Deleuze com Proust não se sustente na célebre explicação utilizada em carta pelo autor ${ }^{120}$, deve ser tomada no sentido preciso de busca da verdade: involuntariamente, o herói empreende um trabalho de interpretação que tem como horizonte a verdade, ora estendendo, ora encurtando, talvez, no ritmo de uma ópera multifacetada, entre conexões simultâneas e blocos sinestésicos, o pensamento que vez a vez se afirma (verdade não conscienciosamente procurada, mas violentamente desejada). É preciso, portanto, compreender como Proust define essa busca da verdade, "como ele a contrapõe a outras buscas, científicas ou filosóficas" ${ }^{121}$; não se trata de identificar, nas franjas diversas de diálogos ou situações romanescas, uma mera circulação de temas apropriados, mas de tomar a Recherche mesma, por conta de seu diferenciado desenho com os signos, como um novo tipo de construção pensante (assunto, pois, absolutamente diferente do que é desenrolado nas teses, por exemplo, de Henry, que na Recherche encontra a projeção de um saber filosófico a ser procurado no romantismo alemão, em Schelling, em Schopenhauer ${ }^{122}$, e de Descombes, que destaca a diferença entre o Proust théoricien de Contre Sainte-Beuve e o Proust romancista da Recherche $\left.{ }^{123}\right)$. Se ela se chama "busca do tempo perdido" é apenas porque, não à volta do tique-taque do relógio, a verdade tem uma relação essencial com o tempo, sendo os signos o objeto de um aprendizado temporal, não de um saber abstrato, exigindo explicações, desenvolvimentos. Que a memória tenha alguma importância, podendose evocar nisto certo platonismo de Proust, um aprender que é ainda relembrar, deve-se a um papel secundário, sendo o tempo passado apenas uma das estruturas de tempo, não a mais importante: "a memória só intervém como o meio de um aprendizado que a excede tanto por seus objetivos quanto por seus princípios" ${ }^{124}$. Os campanários, com as suas superfícies

\footnotetext{
${ }^{120}$ Marcel Proust ([6 février 1914] 1985, p. 98-100): "Considerei mais honesto e mais delicado, como artista, não deixar ver [...] que era precisamente em busca da Verdade que eu partia".

121 PS, p. 23 - PS(br), p. 14.

122 Anne Henry (1983).

123 Vincent Descombes (1987).

${ }^{124}$ PS, p. 10 - PS(br), p. 4
} 
expostas ao sol, vislumbrados sob o ziguezague do veículo nas curvas do caminho, entrecruzados, num instante, pelas batidas luzentes e pelo movimento de traços que aos olhos se desenham ${ }^{125}$, cujos efeitos sibilinos são retomados em outras páginas da Recherche, e a pequena frase musical de Vinteuil, o hino nacional do amor de Swann e de Odette ${ }^{126}$, desdobrada de formas diferentes, numerosas vezes, nos sete volumes, a qual Butor credita uma função estruturante ${ }^{127}$, que não trazem nenhuma ressurreição do passado, têm para Proust muito mais importância do que a madeleine e as pedras irregulares do calçamento, que dependem da memória, ainda que involuntária, e remetem a uma explicação material ${ }^{128}$, invariavelmente ligada à matéria de onde os signos emanam. Em tal perspectiva, o ponto crucial da Recherche é a verdade, não a memória; o tempo é essencialmente o de um aprendizado necessário dos signos, não por habilitação descartável (tempo de uma interpretação); a tarefa se confunde com o desenvolvimento dos próprios signos, os seus desdobramentos ou as suas explicações no tempo (busca temporal, verdade do tempo), tendose que a sistematização de Proust evoca o fato de que o próprio tempo é plural (grande quociente entre o perdido e o redescoberto, cada qual, no aprendizado, com as suas verdades).

Deleuze com Proust, não à propos de rien, introduz o assunto dos signos por meio de uma pergunta muitíssimo consagrada nos estudos proustianos: "Em que consiste a unidade de À la recherche du temps perdu?"129. À complexa equação proustiana, sobre a qual o jovem Beckett pousou a expressão "cada lança pode ser uma lança de Télefo"130, a que fere e a que cura, problema e solução, tornou-se razoável substituir, na própria miríade de aproximações sobre a questão da unidade, a resolubilidade pela dissolubilidade. A crítica genética ${ }^{131}$, a despeito de identificar que o autor imaginou certa unidade para o romance, talvez a dissolva, ao mesmo tempo, com os mapas do inacabamento da obra, especialmente quando ela percebe, pela análise dos manuscritos e dos primeiros entraves editoriais, que Proust fazia imensos recortes, inserções e remendos, incluindo tanto os supostos esboços em Les plaisirs et les jours e no incompleto Jean Santeuil quanto as numerosas especificações, numa centena de cartas e bilhetes, que ajudam a compor na narrativa um Amazonas de detalhes, da cor dos bordados monogramáticos nos guardanapos à forma dos brasões nos talheres usados em

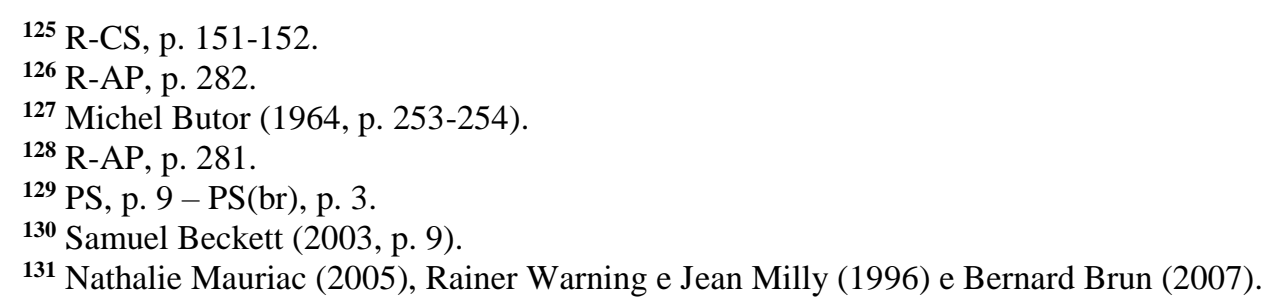


salões aristocráticos. Leituras chamadas formalistas, narratológicas, estilísticas, temáticas, sociológicas ou psicanalíticas ${ }^{132}$, precisando lidar com as variedades, as fissuras e os lapsos da Recherche (por exemplo, como discorre Lavagetto, no livro Chambre 43, a célebre troca, em Le temps retrouvé, do número dos quartos no bordel de Jupien ${ }^{133}$ ), na evidência de certas incongruências episódicas que por vezes se depõem, talvez também a dissolvam por meio de convenções que lhes são próprias em cada caso, embora muitas vezes se mantendo sob um prisma geral que as anima e as serve como matriz, o de um ideal estético que de qualquer modo pressupõe unidade lógica ou totalidade orgânica como construto. A manobra deleuzeproustiana, entretanto, além de se caracterizar como um estado complicado e não exatamente como uma análise literária, diferencia-se por despachar tanto as harmonias entre côncavos e convexos, sejam as do "livro de memórias" ou as da "fábula sobre o tempo", que se tornam divisas, por exemplo, em Ricoeur ${ }^{134}$, ao contestar o alcance de Proust et les signes, ainda que sem desfazer a importância basilar dos signos, quanto o ideal arborescente de um uno capaz de controlar o múltiplo em seu domínio. Mas essa questão só se torna mais clara em "A máquina literária", a segunda parte Proust et les signes, quando, em contraposição à ideia de uma unidade prévia, propõe-se a ideia de partes em frangalhos, constituídas elas mesmas por uma diversidade de fragmentos intermitentes ou desconexos, como lados dissimétricos, direções quebradas, sem formar nem supor um todo: "Pois é exatamente daí que é necessário partir: a disparidade, a incomensurabilidade, a fragmentação das partes da Recherche, com as rupturas, os hiatos, as lacunas, as intermitências que lhe garantem a diversidade final" ${ }^{135}$. Por enquanto, nos limites da primeira parte, trata-se de considerar que os signos constituem a um só tempo a unidade e a pluralidade da Recherche: unidade, apenas no sentido de que todos os "domínios", "campos" ou "mundos" proustianos formam um sistema de signos emitidos por pessoas, objetos, matérias (ou seja, tudo é signo); pluralidade, no sentido de que os signos são heterogêneos, não têm a mesma relação com a matéria na qual estão inscritos, não são emitidos e apreendidos da mesma maneira, não dispõem o mesmo efeito sobre o intérprete, não detêm o mesmo vínculo com o sentido, não trazem o mesmo nexo com as faculdades que os interpretam, não conservam a mesma ligação com as estruturas temporais neles implicadas

132 Gérard Genette (1966), Jean-Yves Tadié (1971), Leo Spitzer (1970), Georges Bataille (1957), Pierre Zima (2002) e Milton Miller (1977).

${ }^{133}$ Mario Lavagetto (1996).

${ }^{134}$ Paul Ricoeur (2010, p. 228-229).

135 PS, p. 140 - PS(br), p. 109. 
e não possuem o mesmo modo de conexão com a essência, quando esta se torna uma espécie de fator de medição do grau de afastamento ou proximidade entre cada signo e o seu sentido.

São esses os quatro tipos de signos da Recherche, numa ordem hierárquico-ascendente: signos mundanos, que aparecem nas relações sociais das personagens, em ocasiões e ambientes variados; signos amorosos, que aparecem nos casos de amor entre as personagens, o do herói por Gilberte, pela duquesa de Guermantes ou por Albertine, o de Swann por Odette, o de Charlus por Jupien, entre outros; signos sensíveis, que aparecem nas impressões ou qualidades sensíveis, a madeleine, os campanários de Martinville, as três árvores, as pedras do calçamento, o barulho de uma colher, o guardanapo, entre outras; e signos artísticos, a mais alta espécie de signos, os do mundo da arte, fornecendo ao intérprete o elemento decisivo para a compreensão de todos os outros signos, reagindo sobre os demais, principalmente sobre os sensíveis, que são então transformados, recebendo a explicação final das características imperfeitas que por um momento apresentavam. Eis que o sistema é pluralista não apenas porque a classificação dos quatro signos utiliza critérios múltiplos, mas também porque dois pontos de vista distintos devem ser conjugados no estabelecimento desses critérios: "Por um lado, devemos considerar os signos do ponto de vista de um processo de aprendizado. [...] Por outro lado, devemos considerar os signos do ponto de vista da revelação final" ${ }^{136}$. Três tipos de signos são "materiais", os mundanos, os amorosos e os sensíveis, por surgirem ainda parcialmente encobertos no objeto que os porta (nos gestos sociais, no rosto da amada), mas também por conta de sua explicação, de seu desenvolvimento, que permanece material, remetendo a alguma coisa que não é o próprio signo (Combray para a madeleine, as jovens para os campanários, Veneza para as pedras do calçamento, Balbec para o guardanapo); apenas um tipo é "imaterial”, os artísticos, tendo-se que, na arte, a matéria se torna espiritualizada e os meios desmaterializados, como ocorre, por exemplo, na pequena frase musical de Vinteuil, não limitada ao piano e ao violino: "as notas surgindo como a 'aparência sonora de uma entidade espiritual" ${ }^{137}$. Quanto ao efeito de cada signo sobre o intérprete, a emoção que suscita, tem-se o seguinte quadro: os mundanos provocam uma exaltação nervosa; os amorosos, angústia ou sofrimento; os sensíveis, súbitas e extraordinárias alegrias (embora haja a exceção da botina e a lembrança da avó ${ }^{138}$, que, não diferindo, em princípio, de outras impressões sensíveis, faz-se como signo de um tempo

\footnotetext{
${ }^{136}$ PS, p. $103-$ PS(br), p. 79.

137 PS, p. $51-$ PS(br), p. 37.

${ }^{138}$ R-SG, p. 623-625.
} 
perdido para sempre, ausência dolorosa); os artísticos, enfim, a alegria pura da arte. A aventura do involuntário se encontra no nível das faculdades que interpretam os quatro tipos de signos, pondo-se cada uma em situação de presença com aquilo que lhe faz despertar. Os mundanos e amorosos são desenvolvidos pela inteligência (que em seguida recorre à memória voluntária), mas sempre uma inteligência involuntária, pois acionada a partir de forças imprevistas, suscitada pela exaltação nervosa da mundanidade ou pelos sofrimentos do amor, obrigada aí a se colocar em movimento, vindo sempre depois; é diferente, portanto, o caso numa filosofia ou ciência racionalista, quando se mobiliza uma inteligência voluntariosa, que vem sempre antes, não nascida de encontros intensivos, organizando-se apenas segundo o $a$ priori de certos métodos ou técnicas. Os sensíveis, por sua vez, são desenvolvidos ora pela memória involuntária (reminiscências que não dependem de um esforço consciente), ora pela imaginação (tal como nasce do desejo), enquanto os artísticos se explicam pelo pensamento puro, a faculdade das essências (tal como revelada na arte). Esses mundos de signos se complementam, cruzam-se, interpenetram-se, convergem: do ponto de vista do aprendizado, nada que se saiba de antemão, mas algo que vai acontecendo, forçando o pensamento; nada que esteja desde sempre e se alcance por boa vontade, mas em dinâmicas de movimentos, deslizes, refrações. São as violências dos signos heterogêneos o que faz o intérprete, o aprendiz, empreender a busca da verdade, sendo ele um quem que a quer segundo o que o força.

Os signos mundanos são os signos vazios da vida mundana, sempre caracterizada por intensa emissão de signos, velozmente concentrados em espaços reduzidos. A mundanidade é o campo dos salões, das vesperais, das festas, das reuniões, das recepções, das cerimônias, com todas as suas idiossincrasias, como se pode ver ao longo da Recherche, entre os Guermantes, entre os Verdurin, na disposição binomial aristocracia-burguesia, incluindo os painéis translúcidos de Le côté de Guermantes, nos quais a atmosfera confinada dos salões se pontua muito claramente pela perda de tempo. Uma simples mímica da Sra. Verdurin ou um cumprimento do duque de Guermantes deve ser interpretado, sendo grandes os riscos de equívoco ou desacerto. Nos encontros sociais, dado o superficialismo que impera, há por vezes situações cômicas, meladas por indolências e tagarelices improdutivas, como a que ocorre na recepção da marquesa de Saint-Euverte, quando Swann, surpreendido pela audição da famigerada sonata, ainda muito emocionado, é interrompido pelo comentário bizarro da condessa de Monteriender, mulher célebre por sua ingenuidade: Maravilhada com o 
virtuosismo dos instrumentistas, a condessa exclamou, dirigindo-se a Swann: - É prodigioso, nunca vi nada tão impressionante. [...] Nada tão impressionante... desde as mesas giratórias! $!^{139}$. É interessante observar, em linhas gerais, como as questões artísticas aqui se apresentam: no círculo dos Verdurin, discute-se arte, mas se elogia apenas os artistas eleitos, os que fazem sucesso, estando empobrecido, assim, o domínio artístico, como valor de troca, esvaziado de um sentido ideal; no círculo dos Guermantes, não é devido comentar a obra de um artista convidado a uma vesperal, os aspectos de sua criação passam ao largo, coisas triviais são faladas, como que não vagamente espremidas por entre os dedos de certa inanidade não contornável. Na vida mundana, os dois mundos se fecham, não funcionando os signos dos Verdurin entre os Guermantes e vice-versa, pois já os dois salões, adornados pelo requinte e pela sofisticação que lhes são peculiares, indicam exigências distintas que têm em comum apenas o fato de serem regidas pelas leis vazias da mundanidade. Há especialidades, constituindo a matéria desse ou daquele mundo - o da diplomacia, o da estratégia militar, o da medicina: "Norpois e o código diplomático, Saint-Loup e os signos estratégicos, Cottard e os sintomas médicos" ${ }^{" 140}$. Mas se pode ser muito hábil em decifrar os signos de uma especialidade qualquer sendo idiota em tudo mais: Cottard, de origem provinciana, é médico, um grande decifrador dos signos da doença; todavia, extraviado, talvez, num ponto qualquer de sua geografia íntima, não é brilhante no salão dos Verdurin; sem ter a malícia burguesa, sem mesmo ter uma minúscula veleidade petite-bourgeoise, além de ser péssimo na decifração dos signos artísticos, não acerta nos gracejos, deles ninguém ri - competente em um caso, ridículo em outros. A mundanidade é recheada de regras tácitas, sendo repertoriada, nas trocas interpessoais, por grandes homens e damas que, cobertos pela manta das convenções, pelo meio onde circulam e pelos ditames de época, desempenham papéis prescritos por suas classes sociais - mas, logo, com o sentido profundo de verdadeiras "famílias mentais", pois vez a vez um Guermantes pode falar como um pequeno-burguês, se a lei da sociedade ou, genericamente, a lei da linguagem, aquém ou além da casta de origem, exige uma fala que se sustente, mais propriamente, numa classe mental $^{141}$. A tarefa do aprendiz, definindo-se o funcionamento da inteligência, não sem o auxílio da memória voluntária, por uma operação fotográfica de classificação e organização, é compreender por

\footnotetext{
139 R-CS, p. 277.

140 PS, p. $11-$ PS(br), p. 4.

141 R-CG, p. 198.
} 
que alguém pode ser recebido em determinado mundo sem sê-lo noutro, a que signos esses mundos obedecem, quem são os seus legisladores e papas.

Os signos amorosos, inseparáveis da força de um rosto, da textura de uma pele, do timbre de uma voz, são os signos enganadores ou mentirosos das relações amorosas, nas quais é possível se conhecer a embriaguez ou a inquietação dos sentimentos. Para além de um pluralismo de amados, aquela possibilidade de um mesmo amante viver múltiplas e sucessivas experiências amorosas, existe um pluralismo inerente a cada ser amado, uma exuberante multiplicidade individual: "Há tantas Albertines que seria preciso dar um nome distinto a cada uma delas e, no entanto, é como se fosse um mesmo tema, uma mesma qualidade sob aspectos variados" ${ }^{\prime 142}$. Essa multiplicidade contida em cada ser amado aparece ao amante enquanto compostos de mundos inacessíveis, uma incógnita, exigindo decifração; amar significa desenvolver ou explicar mundos desconhecidos, tendo-se que, por isso, não raramente se ama alguém de tipo diverso ou alguém que, embora ligado a paisagens conhecidas e desejadas, repercute o conhecido e o desejado, paradoxalmente, de um modo estranho e misterioso. Se a amizade se nutre de observação e conversa, o amor nasce de uma interpretação silenciosa do outro, individualizando-o no meio de um grupo inicialmente homogêneo: “Apaixonar-se é individualizar alguém pelos signos que ele traz consigo ou emite. É tornar-se sensível a esses signos, aprendê-los (como a lenta individualização de Albertine no grupo das jovens)" ${ }^{\prime 143}$. É assim que, em À l'ombre des jeunes filles en fleurs, Albertine aparece, de súbito, pela primeira vez, no ateliê de Elstir, mas ainda entre as outras moças em flor ${ }^{144}$; os seus signos, múltiplos e variáveis, vão sendo particularizados aos poucos, progressivamente, num aprendizado, conforme o ritmo de sensibilidade crescente do intérprete. Em qualquer caso amoroso, a interpretação dos signos do amado faz o amante aportar em mundos que se formaram antes dele, em experiências desdobradas com outras pessoas, tornando-o apenas um entre outros. Os próprios gestos de preferência que o amado dedica ao amante exprimem um mundo desconhecido que o exclui; cada preferência que o amante usufrui delineia a hipótese de que outros amantes também sejam preferidos pelo amado, não gozando ele uma preferência absoluta ou exclusiva; daí a angústia ou o sofrimento que incidem sobre o amante, mesmo quando ele vacila entre motivações reais e imaginárias. Subjetivamente, o ciúme, como desdouro ou nódoa, acaba sendo mais profundo

\footnotetext{
142 PS, p. 84 - PS(br), p. 64.

143 PS, p. 14 - PS(br), p. 7.

144 R-MF, p. 637.
} 
do que o amor (a primeira lei do amor proustiano), como ocorre na relação entre Swann e Odette: Mas logo o ciúme, como se fosse a sombra do amor, se completava com a duplicidade daquele novo sorriso que ela lhe dirigia naquela mesma noite - e que, inverso agora, zombava de Swann e enchia-se de amor por outro ${ }^{145}$. Os signos amorosos são, na verdade, signos de ocultação, pois escondem o segredo de Sodoma e Gomorra, a homossexualidade como a verdade da intersexualidade (a segunda lei do amor proustiano): “objetivamente, os amores intersexuais são menos profundos que a homossexualidade, eles encontram sua verdade na homossexualidade"146. Mas esse nível de homossexualidade, assim como o de intersexualidade, é ainda demasiadamente estatístico, exigindo a compreensão de um terceiro nível, o de transexualidade: a princípio, vive-se sob a predição de Sansão, na qual os dois sexos morrerão cada um para seu lado, como simples divisão dos sexos ${ }^{147}$; depois, tudo se torna complicado, pois os sexos separados, divididos, coexistem no mesmo indivíduo. Eis então a ideia de um hermafroditismo inicial ${ }^{148}$, que transita na metáfora vegetal de Sodome et Gomorrhe: no infinito dos amores, está o hermafrodita, dotado de dois sexos, mas incapaz de fecundar-se; ele precisa de outro hermafrodita para que a parte feminina seja fecundada ou a parte masculina possa fecundar; o problema é que o intermediário, o inseto que porta a semente do outro, ao invés de assegurar a aliança macho e fêmea, "desdobra cada sexo em si mesmo" "149; os amantes, diz Proust, representam, para a mulher que ama as mulheres, o papel de uma outra mulher, e a mulher lhes oferece, ao mesmo tempo, mais ou menos aquilo que eles encontram num homem ${ }^{150}$.

Os signos sensíveis são os signos verídicos das impressões ou qualidades sensíveis, signos decisivos, preparando a revelação da arte, formando já um começo da arte ${ }^{151}$. Superiores aos amorosos e mundanos, ainda que inferiores aos artísticos, proporcionam estranhas alegrias, como na ocasião em que o herói, estando no pátio do palacete de Guermantes, tropeça nas pedras irregulares do calçamento, revivendo então os ladrilhos desiguais do batistério de São Marcos em Veneza ${ }^{152}$, ou como na famosa experiência da

\footnotetext{
145 R-CS, p. 221.

146 PS, p. 17 - PS(br), p. 10.

147 R-SG, p. 511.

148 R-SG, p. 522.

149 PS, p. 98 - PS(br), p. 75

150 R-SG, p. 516.

151 R-TR, p. 679.

152 R-TR, p. 661-662.
} 
memória involuntária com a madeleine ${ }^{153}$, cujo desenvolvimento, desencadeado na materialidade de um sabor, serve aqui como exemplo: Mas no mesmo instante em que esse gole, misturado com os farelos do biscoito, tocou meu paladar, estremeci, atento ao que se passava de extraordinário em mim. Invadira-me um prazer delicioso, isolado, sem a noção de sua causa. Afirmativos como um vento elegante, distinguindo-se dos precedentes por seu efeito imediato, os signos sensíveis também provocam uma espécie de imperativo, de sentimento de obrigação, necessidade de um trabalho do pensamento: De onde poderia ter vindo essa alegria poderosa? Sentia que estava ligada ao gosto do chá e do biscoito, mas ultrapassava-o infinitivamente, não deveria ser da mesma espécie. De onde vinha? Que significaria? Onde apreendê-la?. A impressão sensível enseja um sentimento de plenitude, descrito pelo narrador como algo que ultrapassa infinitamente o que se dá no encontro extensivo - e que não é da mesma espécie. Eis Deleuze com Proust o que diz: "Uma vez experimentada, a qualidade não aparece mais como uma propriedade do objeto que a possui atualmente, mas como o signo de um objeto completamente diferente, que devemos tentar decifrar, num esforço sempre sujeito a fracasso"154. O sentido do signo, afinal, aparece, revelando o objeto oculto - signo material, assim, na origem e na explicação: E de súbito a lembrança me apareceu. Aquele gosto era o do pedacinho de madeleine que minha tia Léonie me dava aos domingos pela manhã em Combray. Cada vez que intervém a memória, a explicação comporta alguma coisa de material (Combray, Veneza), mas o esforço de interpretação não termina; é que as impressões ou qualidades sensíveis, mesmo quando bem interpretadas, não são em si mesmas suficientes, o que faz entender por que Proust, bem adiante, visando uma nova etapa da interpretação, refere-se à madeleine, de certa forma, como um fracasso: Com efeito, a felicidade que eu acabava de experimentar era exatamente igual à que sentira ao comer a madeleine, e de cujas causas profundas tivera, naquele tempo, de adiar a pesquisa ${ }^{155}$. Em Le temps retrouvé, quando as impressões sensíveis subitamente se multiplicam num pequeno intervalo de tempo (as pedras do calçamento, o barulho de uma colher, o guardanapo), ainda resta explicar por que Combray não ressurgiu tal como esteve presente (simples associação de ideias), mas sob uma forma jamais vivida; ainda resta explicar por qual razão alegrias tão incomuns, intensas e particulares foram sentidas: $D a$ mesma forma o sabor da pequena madeleine me lembrava Combray. Mas por que motivo as

\footnotetext{
153 R-CS, p. 51-53.

154 PS, p. 18 - PS(br), p. 10-11.

155 R-TR, p. 662.
} 
imagens de Combray e de Veneza me haviam, num como noutro momento, comunicado uma alegria semelhante à certeza e suficiente, sem outras provas, para me deixar indiferente à morte? ${ }^{156}$.

Os signos artísticos, os últimos, são os signos essenciais da arte, superiores aos outros, agitando o nível mais profundo: "Qual é a superioridade dos signos da Arte com relação a todos os outros? É que todos os outros são signos materiais. [...] Apenas os signos da arte são imateriais" ${ }^{157}$. Evidentemente, o campo da arte superabunda na Recherche, sob a forma de numerosos comentários, descrições e sensações; ele se apresenta pelos sons de um Beethoven, de um Wagner ou de um Debussy, pelas tintas de um Vermeer, de um Manet ou de um Renoir, pelas letras de um Balzac, de um Baudelaire ou de um Flaubert, incluindo notáveis discussões sobre Dostoiévski, mas também, especialmente, pelas obras dos três artistas imaginários, o escritor Bergotte, o pintor Elstir e o músico Vinteuil, sendo recorrentes, pois, os casos da literatura, da pintura e da música. Com efeito, Proust elabora uma visão da arte e da relação da arte com a vida mundana, amorosa e sensível, tornando-a o âmbito essencial do seu sistema de pensamento. Há semelhanças, sem dúvida, entre os efeitos dos sensíveis e dos artísticos, pois ambos são signos "alegres": Assim, nada se assemelhava mais do que uma bela frase de Vinteuil a esse prazer especial que às vezes eu sentira na vida, por exemplo, diante dos campanários de Martinville, de certas árvores de uma estrada de Balbec ou, mais simplesmente, no começo desta obra, ao beber uma taça de chá ${ }^{158}$. Contudo, somente os signos artísticos suscitam uma "alegria pura" - desde sua imaterialidade, irredutível aos objetos que os emitem, e desde seu sentido, inteiramente espiritual, uma essência ideal (sentido-essência). Não meras notas, por exemplo, mas signos com um valor que não é encontrado em outros signos: a pequena frase musical de Vinteuil, aliciando e envolvendo Swann, brota dos instrumentos musicais, podendo ser decomposta materialmente, em sentido matemático, devida à leve separação entre as cinco notas que a compunham e à evocação constante de duas delas (cinco notas muito unidas, duas se repetindo); mas essa combinação mecânica de notas nada explica, pois Swann sabe que o campo aberto ao músico não é um teclado mesquinho de sete notas, mas um teclado incomensurável, aparecendo o piano, portanto, apenas como a imagem espacial de um teclado de natureza diferente; daí que as notas surjam como a aparência sonora de uma entidade espiritual, como se os instrumentistas

\footnotetext{
156 R-TR, p. 663.

${ }^{157}$ PS, p. 51 - PS(br), p. 37.

158 R-AP, p. 281.
} 
muito menos tocassem a pequena frase do que executassem os ritos exigidos por ela para que aparecesse, sendo a própria impressão da frase, desse ponto de vista, sine materia ${ }^{159}$. Na arte, o verdadeiro tema não é o assunto tratado, mas os temas inconscientes, os arquétipos involuntários, dos quais as palavras, as cores e os sons tiram o seu sentido e a sua vida. É que a arte envolve matérias (a cor para o pintor, o som para o músico, as palavras para o escritor), mas essas matérias "são dúcteis, tão bem malaxadas e desfiadas que se tornam inteiramente espirituais"160; de modo mais profundo, são "matérias livres", como blocos de pedra que se desmaterializam. A arte tem, assim, um privilégio absoluto: matéria espiritualizada e meios desmaterializados, sentido-essência, perfeita adequação entre signo e sentido.

Tudo faz parte de um aprendizado que diz respeito a signo, sentido, essência - seja por um suspiro estendido entre pares ou pela graciosa manobra de um braço, seja pelas ranhuras de um rosto ou pelas intensas alegrias de uma visão azul se arredondando em azuladas mamas ao se enxugar a boca num guardanapo, seja ainda pela entonação da atriz, em Phèdre, de Racine, ou pelo pastiche das obsessões naturalistas dos irmãos Goncourt: "As noções da Recherche são: o signo, o sentido, a essência; a continuidade dos aprendizados e o modo brusco das revelações"161. Há sempre sentidos enrolados, envolvidos ou implicados nos signos, o que não quer dizer significações explícitas ou ideias claras; à implicação, corresponde o desenrolamento, o desenvolvimento, as "imagens de explicação" dos signos, conforme a maturação contínua e progressiva do intérprete. Em outras palavras, o sentido, enrolado, envolvido ou implicado no signo, não existe previamente, devendo ser produzido; é ele o efeito de uma fabricação desencadeada no pensamento por violências: "O homem sensível libera as almas implicadas nas coisas, um pouco como quem vê os pedaços de papel do jogo japonês desdobrando-se na água, estirando-se ou explicando-se, ao formar flores, casas e personagens"162. Desenvolver ou liberar águas parceiras, nuvens vivas, ventos do ninar; onde há catástrofe, grande ou pequena, explicita-se a trama entre signo e sentido, de um mínimo de causa para um máximo de consequência: signo, que é do sentido o enrolamento, o envolvimento, a implicação; sentido, que é do signo o desenrolamento, o desenvolvimento, a explicação. Proust, aliás, transita na ideia de alma prisioneira, gostando de certa crença céltica: Acho bem razoável a crença céltica de que as almas das pessoas que perdemos se

\footnotetext{
159 R-CS, p. 275, 274 e 172.

${ }^{160}$ PS, p. 60 - PS(br), p. 44.

161 PS, p. 111 - PS(br), p. 85.

162 PS, p. 110 - PS(br), p. 84.
} 
mantêm cativas em algum ser inferior, um animal, um vegetal, uma coisa inanimada [...] Libertas por nós, elas venceram a morte e voltam a viver conosco ${ }^{163}$. Assim surge, assim começa, mais propriamente, toda a foto-cinematografia do pensamento: uma mão colide subitamente com um objeto, cercando-o de palma e dedos; no inelutável clarão de um valoroso instante, mesmo quando não tardam noções diminutas ou semiapagadas, as tensões e os estremecimentos, palpitando como pernas de acrobatas e dançarinos, dão ao intérprete, mais do que uma oportunidade, o dever de desenvolver, produzir, liberar. Só aquele que, numa situação concreta, está sob alguma fúria, alguma arcada de dínamos, num deslocamento inexaurível, adequando-se então, por conta da coação dos signos, a uma intensidade desmesurada, à subitaneidade de uma visitação que, a julgar por uma hipotética geometria de espasmos, propõe-se, talvez, como triangulação de formas variegadas em outras formas - só o refém de violências, este agredido, busca a verdade, põe-se a pensar.

Poder-se-ia, sem dúvida, atribuir à busca vários assuntos proparoxítonos: talvez, um esdrú-xu-lo, como um sono, semissono ou semidespertar das primeiras páginas; um náu-fra-go, como um mergulhar na memória; um gra-má-ti-co, como uma filosofia do tempo; um mo-nóto-no, como um retorno constante de situações e personagens; um dra-má-ti-co, como um insano "quero escrever e não consigo"; um cá-li-do, como uma vocação literária. Não indisciplinadamente, até mesmo um estudioso dos Oitocentos, como Mayer, pode se servir de cenas da Recherche como documento histórico, ao discorrer sobre aspectos da sociedade francesa, como a sobrevivência de traços do Antigo Regime na Terceira República ${ }^{164}$. Mas, aqui, pela sombra abismada no intérprete, experiências em estilhaços que, por dores, desgostos e súbitos contentamentos, convergem para o mundo das essências reveladas na arte, cabe a enrabada conceitual deleuziana, não sem esconder aquilo que não lhe interessa e superestimar aquilo que lhe interessa, implicando-se nela, antes de tudo, como um ladrão, "sempre 'fora' e 'entre'”, que lhe abre as janelas do vestido. É que a questão deleuzeproustiana, nas articulações pelas quais filosofia e literatura se complicam, não visa estabelecer um mero arranjo seletivo e tipológico dos signos, tampouco organizar os elementos romanescos que supostamente poderiam oferecer aos leitores de Proust um desvendamento da Recherche; sua modalidade prática é sempre a criação de conceitos, em

${ }^{163}$ R-CS, p. 51.

${ }^{164}$ Arno Mayer (1987, p. 113). 
lugar particular, o domínio filosófico, numa aliança do tipo ciclista e bicicleta com a literatura, resolvendo pelo seu lado e com os seus próprios meios "a lógica" dos problemas afins que participam no outro domínio. Como diz Lapoujade, Deleuze é um lógico: "Ele não busca estabelecer nem a estrutura narrativa da Recherche, nem uma profundidade qualquer de análise psicológica, mas quer produzir a lógica que ela envolve como numa crisálida"165. Já se disse que o que está em cena é o problema da gênese do pensamento: o ato de pensar depende de um encontro casual com os signos, não de uma decisão premeditada; os signos violentam o pensamento, tirando-o de seu natural estupor, de suas possibilidades apenas abstratas, como um assédio fortuito e inevitável. Apresentam-se, pois, as condições reais do pensar, sem pressupostos, não antecipado por categorizações preliminares nem por metodologias artificialmente decididas. No desígnio abrupto e intempestivo dos signos, o automatismo das miragens do pater e da mater é substituído, assim, pela aventura do pensamento involuntário, constrangido: "É preciso, antes de qualquer coisa, experimentar o efeito violento de um signo, e que o pensamento seja como que forçado a procurar o sentido do signo"166. Para Deleuze com Proust, essa dinâmica signo-pensamento encerra, na Recherche, uma crítica "eminentemente filosófica", em rivalidade com a filosofia em seu registro clássico, cujo erro seria o de "pressupor em nós uma boa vontade de pensar, um desejo, um amor natural pela verdade" 167 . No início da segunda parte de Proust et les signes, diz-se claramente: "À̀ observação Proust opõe a sensibilidade. À filosofia, o pensamento. À reflexão, a tradução. Ao uso lógico ou conjunto de todas as nossas faculdades [...] um uso dislógico e disjunto que mostra que nunca dispomos de todas as faculdades ao mesmo tempo e que a inteligência vem sempre depois"168. Tem-se em Proust, portanto, uma nova imagem do pensamento: "Proust constrói uma imagem do pensamento que se opõe à da filosofia. Ele combate o que há de mais essencial numa filosofia clássica de tipo racionalista. Ele ataca os pressupostos dessa filosofia" ${ }^{169}$. O desejo voluntário pelo verdadeiro deixa de ser o elemento do pensamento, por estarem em jogo agora apenas relações de pressão: pensamento forçado a buscar a verdade.

Esse conceito de imagem do pensamento atravessa toda a obra de Deleuze e DeleuzeGuattari, retorcendo-se infinitésimas vezes nas vibro-variabilidades que lhe são constituintes, embora sempre se desenvolvendo mais ou menos sob a forma de uma distinção: imagem

\footnotetext{
165 David Lapoujade (2015, p. 12).

${ }^{166}$ PS, p. 32 - PS(br), p. 22.

167 PS, p. $24-\mathrm{PS}(\mathrm{br})$, p. 15.

168 PS, $128-129-\mathrm{PS}(\mathrm{br})$, p. 100.

${ }^{169}$ PS, p. 115 - PS(br), p. 88.
} 
dogmática e nova imagem do pensamento (ou pensamento sem imagem). Um minúsculo e despretensioso recorte de vizinhança, limitado a Nietzsche et la philosophie, Proust et les signes e Différence et répétition, pode oferecer por agora alguma visão de seus primeiros movimentos. Em Nietzsche et la philosophie, no capítulo "A crítica", apresentam-se as três teses essenciais da imagem dogmática: a primeira diz que o pensador, enquanto pensador, quer e ama o verdadeiro, que o pensamento possui formalmente o verdadeiro (inatismo da ideia, o a priori dos conceitos), que pensar é o exercício natural de uma faculdade, que bastaria então pensar "verdadeiramente" para se pensar com veracidade (natureza reta do pensamento, bom senso universalmente partilhado); a segunda diz que se é desviado do verdadeiro por forças estranhas ao pensamento (corpo, paixões, interesses), que se pode cair então no erro, tomando-se o falso pelo verdadeiro; a terceira diz que, para se pensar, é preciso apenas um método, providencialmente louvado, neste caso, como o artifício irrevogável para se pensar bem e verdadeiramente (ilusão, talvez, de toda filosofia ou ciência racionalista). Nietzsche teria retorcido completamente essa imagem dogmática ao introduzir no pensamento as noções de sentido e valor, não tendo "o verdadeiro" como elemento (ideia moral), fazendo do pensamento ativo uma crítica da tolice e da baixeza: “As categorias do pensamento não são o verdadeiro e o falso, mas o nobre e o vil, o alto e o baixo, segundo a natureza das forças que se apoderam do próprio pensamento" ${ }^{170}$. Em Proust et les signes, no capítulo "A imagem do pensamento", veste-se tal imagem dogmática, como já foi dito, na chamada imagem racionalista da filosofia clássica: o pensador ama e quer naturalmente o verdadeiro; para não tomar o falso pelo verdadeiro, basta ele ter um método eficaz (boa vontade do pensador e decisão premeditada). Proust teria construído uma nova imagem do pensamento ao fazer dos signos o objeto de encontros intensivos, gênese do ato de pensar no próprio pensamento: pensa-se, busca-se a verdade, somente sob a pressão dos signos. Em Différence et répétition, no capítulo "A imagem do pensamento", formula-se a crítica da imagem dogmática (ortodoxa, moral) segundo os oito postulados que a projetam: o princípio da Cogitatio natura universalis (boa vontade do pensador e boa natureza do pensamento), o ideal do senso comum (como concordia facultatum), o modelo de recognição (instigando todas as faculdades a se exercerem sobre um objeto supostamente o mesmo), o elemento da representação (a diferença subordinada às dimensões complementares do Mesmo e do Semelhante, do Análogo e do Oposto), o negativo do erro (como o efeito das forças externas a se oporem ao 
pensamento), o privilégio da designação (como o lugar da verdade), a modalidade das soluções (os problemas materialmente decalcados sobre as proposições ou formalmente definidos pela possibilidade de serem resolvidos) e o resultado do saber (a subordinação do aprender ao saber e da cultura ao método). Movimenta-se neste livro, porém, uma complexidade muitíssimo ambiciosa, transbordando-se, pontualmente, na ultrapassagem da própria terminologia "imagem", como reivindicação agora de um pensamento "sem imagem", que não sabe previamente o que significa pensar e deve incessantemente retornar ao ato que o engendra: "O pensamento que nasce no pensamento, o ato de pensar engendrado em sua genitalidade, nem dado no inatismo nem suposto na reminiscência, é o pensamento sem imagem" ${ }^{171}$. Eis então, em Différence et répétition, o apelo a uma filosofia que encontraria a sua diferença exatamente numa luta contra a imagem dogmática, "mesmo que fosse à custa das maiores destruições, das maiores desmoralizações, e com uma obstinação da Filosofia que só teria como aliado o paradoxo, devendo renunciar à forma da representação assim como ao elemento do senso comum"172.

Em suma, todo o problema do pensamento (ou das imagens do pensamento), apresentando transformações implícitas e explícitas em seu desenvolvimento, é essencial em Deleuze e em Deleuze-Guattari, não menos do que uma obsessão, como afirma o próprio filósofo em Pourparlers, registrando-o eventualmente num pequeno inventário de livros: Proust et les signes, com toda a potência dos signos proustianos que se opõe "à imagem grega" do pensamento; Différence et répétition, com "a natureza dos postulados na imagem do pensamento"; Logique du sens, "onde a altura, a profundidade e a superfície são coordenadas do pensamento"; Mille plateaux, com o conceito de rizoma, uma imagem do pensamento "que se estende sob a imagem das árvores" ${ }^{173}$. Em Logique de la sensation, com Bacon, atravessando também outras produções pictóricas (Cézanne, Kandinsky, Mondrian), estendem-se as malhas, como capturas de entrelaçados em curvas e contracurvas da noologia. Deleuze com Bacon, distinguindo, como diz Kossovitch, "entre o cerebrino da narração e o nervoso da pintura, entre a ação indireta na ilustração e a direta na imagem" ${ }^{174}$, encontra no pintor um exercício do pensamento que pretende neutralizar a narração, a ilustração, a figuração; é que Bacon apresenta, mais propriamente, uma figura não figurativa, como que a

\footnotetext{
171 DR, p. 273.

172 DR, p. 220.

${ }^{173}$ C, p. 190.

${ }^{174}$ Leon Kossovitch (2003, p. 161)
} 
pintar a sensação, não os efeitos da sensação; ao estilhaçar a representação, a figura não figurativa é catástrofe, torna-se paradoxal. Em L'image-mouvement e L'image-temps, o problema insiste na forma de uma classificação das imagens e dos signos cinematográficos, aprofundando-se agora, como defende Cardoso, "a disposição favorável com relação ao pensamento de Peirce" ${ }^{175}$, ainda que não completamente. Para Deleuze, o cinema pensa com imagens-movimento (cinema clássico: tempo subordinado ao movimento) ou com imagenstempo (cinema moderno: movimento subordinado ao tempo). Enfim, não sem algum déficit nessas citações demasiadamente velozes das obras, em Qu'est-ce que la philosophie? a imagem do pensamento é o plano de imanência, que com as personagens conceituais forma as endocondições para a criação de conceitos: "O plano de imanência não é um conceito pensado nem pensável, mas a imagem do pensamento, a imagem que ele se dá do que significa pensar, fazer uso do pensamento, se orientar no pensamento..." ${ }^{176}$. É evidente, pois, que a formulação signo-pensamento, ao sabor de diferentes pautas problemáticas, implica crescentes e multívocas dificuldades; em qualquer ponto, considerando qualquer intercomunicabilidade dos livros, torna-se ela, para o leitor do filósofo, um bom obstáculo: como se mover nos embaraços das linhas e redes diversas que se distribuem por toda parte? Faz-se, assim, a necessidade de cruzá-la a partir daquilo que é crucial em Proust et les signes, sem deixar de sê-lo em toda a obra deleuziana: na mundanidade, no amor, nas impressões sensíveis ou na arte, a violência dos signos é o que lança o pensamento num devir-ativo. Ou, de outro ponto de vista, faz-se a necessidade de conectá-la num entre livros, mas em termos de respiradores lisos ou jugulares abertas, rompendo contratos de calendário, segundo o que nele permanece crucial.

\footnotetext{
175 Hélio Rebello Cardoso Jr (2006, p. 205).

176 QF, p. 47.
} 


\section{TRÊS}

Quer ver, comidas as batatas, o quadro: um pequeno lanço de muro amarelo, afora a superfície de água que ampara, em reflexos calmos e nebulosos, tanto os edifícios de Delft quanto o enorme firmamento, através do qual se rompe um tímido sol, mas suficiente para revelar, entre zonas luminosas e sombreadas, os sulcos nas paredes das igrejas, a ponte que leva aos estaleiros, os barcos em estação, as personagens em azul, a areia rósea, Nieuwe Kerk. Ser sensível aos signos é um dom, mas esse dom corre o risco de permanecer oculto enquanto não acontecem os encontros necessários; julgava o escritor conhecer esse Vermeer muito bem, tendo talvez notado, por exemplo, que nele, ao fundo, as nuvens brancas escondem o horizonte, criando a distância que desprende a cidade do céu, que prevalecem, à esquerda, as linhas horizontais dos telhados, assim como prevalecem, à direita, os troncos pontiagudos das torres, ou que a paisagem urbana possui algo de matemático, dadas as relações exatas entre o vigor das cores e o efeito de luz sobre as formas coloridas; mas agora, na exposição de arte holandesa, prestes a morrer, ele repara, surpreso, conforme um crítico outrora havia apontado, a preciosa matéria do pedacinho bem pequeno de muro amarelo, repara-a, assim, detidamente, como procede a criança com uma borboleta amarela a que pretende agarrar ${ }^{177}$; é que nesse nível, sugere Deleuze com Proust, o quadro não vale como um todo, mas "pelo pequeno detalhe de parede amarela nele colocado como fragmento de um outro mundo"178. Nos encontros intensivos, tal qual o de Bergotte com o Vista de Delft, sente-se como experiência complexa qualquer atração ou repulsa expressiva; na verdade, outros mundos aí se desenlaçam, hospedando atmosferas que transbordam as situações vividas, abrindo virtualidades que não se esgotam na recognição, outros mundos co-presentes em cada situação, insistentes naquilo que foi dado no encontro acidental, mas indomesticáveis ao que aparece no próprio dado. Swann e a pequena frase musical de Vinteuil é um encontro do mesmo tipo, arremessando o participante a uma realidade acima das coisas concretas, despertando nele a sede de um encanto desconhecido que não pode ser estancado, tornando inútil a sua inteligência; o narrador descreve que o prazer que lhe dava a música, prazer que

177 R-AP, p. 141.

178 PS, p. 138 - PS(br), p. 108. 
em breve iria criar nele uma verdadeira necessidade, parecia-se com o prazer que ele teria em entrar em contato com um mundo para o qual não somos feitos, que nos parece informe porque nossos olhos não o distinguem, e sem significado porque escapa à nossa inteligência, e que só conseguimos alcançar através de um único sentido ${ }^{179}$. Em face de um signo, pode-se sentir a abertura dessas dimensões estranhas, não colonizáveis nem manejáveis, como mundos não familiares, insistentes numa aparição, mas relativamente não pacificados ou saciados nela; como diz Zourabichvili, o mundo exterior, no qual se tece o existir, "devém interessante" somente na medida em que ele "faz signo e perde assim sua unidade tranquilizadora, sua homogeneidade, sua aparência verídica" ${ }^{180}$. Imprevisto, o hieróglifo plana despojadamente na sensação, acima ou abaixo de nuvens intermediárias: não operam as relações do signo com um domínio de referência e, por mais que se insinuem, não contestam o breu.

Deleuze com Proust não formula diretamente o que é um signo, privilegiando-o por seu funcionamento (emissão e interpretação, produção e multiplicação); o filósofo tem, aliás, ao longo de suas obras, uma noção plurívoca de signo, não formalizada nem especificada, feito uma colcha de retalhos, em agitação intrínseca, mantendo diversificadas conexões com outros conceitos, a cada vez por novas e inauditas disposições de elos, esperneando-se entre vidros e coitos, mantida sempre em interesse ${ }^{181}$; o privilégio do funcionamento do signo na Recherche demanda, contudo, exatamente aquilo que, em qualquer caso, faz-se essencial: o signo é o objeto de um encontro, que envolve sensação, que dispara busca de sentido. É possível se encontrar na vida, por exemplo, um Beethoven, um Degas ou um Balzac, assim como se encontra um arame, uma pinça, um bandolim, uma ratazana, um botão, uma laranja, um parasita, uma dracma, um sapato, uma ferradura (seres, coisas, ideias); os encontros podem ou não constituir um campo problemático, dependendo das circunstâncias, se eles apenas confirmam as perspectivas regulares, condecorando-as com as plumas do reconhecimento (é uma sonata em mi bemol maior, é uma bailarina, é Lucien de Rubempré), ou se eles extrapolam completamente essas perspectivas. Há o nível do encontro extensivo, lance ordinário ou trivial, que não constitui em si mesmo um problema para o pensamento: uma boca encontra alguns biscoitos curtos e rechonchudos, gostosos. Mas também há o nível do encontro intensivo, lance extraordinário ou excepcional, que constitui em si mesmo um

\footnotetext{
179 R-CS, p. 193.

${ }^{180}$ François Zourabichvili (1996, p. 37).

181 C, p. 87.
} 
verdadeiro problema para o pensamento: algo eventualmente acerta, espanta, encanta, apavora, faz pensar - desmontando, assim, todo o quadro de referências do desprevenido, do despreparado, lançando-o num devir-ativo. Que Combray ressurja, não exatamente como foi vivida, mas com um esplendor, com uma verdade que nunca teve equivalente, revelando já uma imagem da eternidade, deve-se ao encontro do herói com o signo sensível, cuja especificidade casual garante, ali, sem outras provas, a necessidade do que é pensado. Encontro extensivo: o que toca o paladar, o sabor do chá e do biscoito na boca, a gostosura dos farelos da madeleine na cavidade bucal. Encontro intensivo: não o pedaço do objeto na língua, molhado, mas o acontecimento que não é dado no dado, o prazer possante que invade o herói, assaltando-o, enchendo-o de uma essência preciosa, tornando inofensivos os desastres da vida e ilusória a sua brevidade, tornando-o, por ser tudo satisfatório, indiferente mesmo à morte, uma felicidade incomum, embora com interpretação ainda em fracasso, de cujas causas profundas tivera, então, de adiar a busca. Na vida, todo encontro banal, seja com o grafite de um lápis fincado num dedo, seja com os fiapos de uma manga entalados nos dentes, está vulnerável à possibilidade de alguma cambalhota ou pirueta instantânea, não premeditada, que intempestivamente sapeca tudo para fora dos eixos, como perturbação, abalo, tremedeira, cintilação. O que constitui o campo problemático é o funcionamento do signo, mais propriamente, nesse nível intensivo dos encontros, insubmisso à obragem rotineira, primeiramente sentido, não ligado a um exercício intelectual preliminar, mostrandose alienígena ou terra incógnita; é que os signos são signos somente quando constituem um problema para o pensamento, quando o forçam, tendo o estatuto paradoxal do não reconhecido e, porém, encontrado: "não mais objetos reconhecíveis, mas coisas que violentam, signos encontrados" ${ }^{\prime 182}$.

Que a efetiva complexidade dos encontros se inflame na passagem do extensivo ao intensivo, quando o pedacinho de muro amarelo em Vermeer, a pequena frase musical de Vinteuil ou a madeleine servida pela mãe se torna o fragmento de outro mundo, deve-se a este ponto crucial: não se trata de reconhecer algo que o pensamento sabe. É verdade que, de uma forma geral, os atos de recognição ocupam grande parte da vida cotidiana (é um quadro, é uma música, é um biscoito); mas quem pode acreditar que o destino do pensamento aí se joga e que se pensa quando se reconhece? ${ }^{183}$. No nível extensivo, reconhece-se um quadro como

\footnotetext{
182 PS, p. 123 - PS(br), p. 94. ${ }^{183}$ DR, p. 224.
} 
quadro, as linhas horizontais dos telhados e os troncos pontiagudos das torres, ou uma música como música, a combinação mecânica de notas, cinco notas muito unidas, duas se repetindo, ou um biscoito como biscoito, parecendo ele ter sido moldado na valva estriada de uma concha de São Tiago; é um exercício inteiramente ordinário que, desprovido de aventuras estranhas, não sem descobrir a sua finalidade prática em valores estabelecidos, adjetivando-os com crédito ou descrédito, adornando-os com louros ou desonras, pois comprimido, afinal, em duas instâncias complementares, o senso comum (norma de identidade, concordia facultatum) e o bom senso (norma de partilha que garante a concordia facultatum), deixa o pensamento inativo ou apenas com uma aparência de atividade, incapaz de não ser fleumático. Nos registros das percepções regulares, há um modelo de recognição, que se define, conforme Différence et répétition, "pelo exercício concordante de todas as faculdades sobre um objeto suposto como sendo o mesmo: é o mesmo objeto que pode ser visto, tocado, lembrado, imaginado, concebido..."184; as faculdades (por exemplo, a memória, a imaginação) se reportam ao objeto da experiência com os dados particulares que cada uma tem para lidar com ele (o memorável, o imaginável), mas enfim todas elas concordam, chegam a um resultado idêntico, o mesmo objeto (acordo harmonioso, uso lógico ou conjunto das faculdades). Esse modelo, fundado na ficção de uma "alma total" ou sujeito pensante tido como universal, tem nos pressupostos de uma inteligência voluntariosa, que vem sempre antes, o precedente da concordância das faculdades; em filosofia, ele é o modelo compreendido na imagem dogmática do pensamento: "Quer se considere o Teeteto de Platão, as Meditações de Descartes, a Crítica da razão pura de Kant, é ainda este modelo que reina e que 'orienta' a análise filosófica do que significa pensar" ${ }^{" 185}$. No nível intensivo, ao contrário, os deuses do reconhecimento não são encontrados, mas uma frenética violência, um coup de main que exige um trabalho do pensamento; ele é invadido por forças que, não sendo as da recognição, são as de um "encontro fundamental", ambiente da falência ou ineficiência do sentido trivial, como que lançando sobre os defuntos uma pá de terra molhada, mais densa, mais espessa, deixando a alma perplexa. Zourabichvili traz o sentido forte desse encontro intensivo: "Encontrar não é reconhecer: é a prova mesma do não-reconhecível, o colocar em xeque o mecanismo de recognição" ${ }^{186}$. Na Recherche, segundo a complicação deleuze-proustiana, há um uso dislógico e disjunto das faculdades, isto é, não se dispõe ao mesmo tempo de todas as

\footnotetext{
184 DR, p. 221.

185 DR, p. 223.

${ }^{186}$ François Zourabichvili (1996, p. 37).
} 
faculdades e a inteligência vem sempre depois; pode-se dizer que a relação entre as faculdades se dá num "acordo discordante", fazendo com que o encontro intensivo com os signos seja a única razão do ato de pensamento; nos encontros, dado o acordo discordante, cada faculdade não tem outra aventura senão a do involuntário, que é, guardadas as diferenças, um dos aspectos do platonismo proustiano: inteligência involuntária, para os signos mundanos e amorosos; memória involuntária e imaginação involuntária, para os signos sensíveis; em suma, pensamento puro, involuntário, como faculdade das essências, para os signos artísticos.

O bom encontro é sempre acidental, obra do acaso, não deliberado por uma soberana ou autoafirmadora liberdade subjetiva, desconhecendo o aprendiz a condição pela qual ele pode ser afetado: Porém é, às vezes, no justo momento em que tudo nos parece perdido, que ocorre o aviso que nos pode salvar; batemos a todas as portas que não abrem para nada, e na única pela qual podemos entrar, e que teríamos buscado em vão durante um século, esbarramos por acaso e ela se abre ${ }^{187}$. O acontecimento é autêntico, pois não procurado, diz Proust noutra ocasião: E percebia nisso a marca de sua autenticidade. Não fora procurar as duas lajes regulares do pátio onde tropeçara ${ }^{188}$. É verdade que há o plano das condições, por assim dizer, extensionais: num determinado empreendimento, alguém se decide por uma direção $x \mathrm{e}$ não por uma direção $y$, seja o esnobe que se arruma para uma vesperal com os mais requintados adornos, seja o ciumento que não hesita em formular suspeitas atrozes acerca de fatos inocentes, podendo ele prever, como um filósofo que decide caminhar com outro filósofo, o volume fotográfico de seus próprios movimentos ou repousos, o alcance de suas próprias acelerações ou procrastinações, mesmo que essencialmente desconhecendo a cilindragem dos fluxos que, como fantasmas horripilantes, adiantam-se já no horizonte, sugerindo por vezes as esquisitas silhuetas de suas cabeças, mas sem nunca se deixarem flagrar de fato, ameaçando, assim, de modo contínuo, lançarem-se ferozmente, agora ou logo mais, contra tudo o que está sendo planejado. Mas também há o plano das condições, por assim dizer, intensionais, que é justamente o plano caro à complicação deleuze-proustiana; trata-se, na verdade, de um não-plano, pois ele não tem o sentido de projeto ou programa: os bons encontros envolvem a inesperada fulguração que, como improvisação, como ideiacinema, pode se desdobrar no aqui e agora da experiência, sem que se possa prevê-la, o que

187 R-TR, p. 661.

188 R-TR, p. 671. 
rebate quaisquer escolhas para um jogo não premeditado nem regrado de sensações; os fantasmas não se antecipam no horizonte, tampouco sugerem nas sombras a forma de suas silhuetas; fazem-se por surpresa, espontâneos, como um sol que, numa estrada, estando os passageiros de um carro, dada a longa viagem, em terrível sonolência, lança repentinos e intermitentes raios luminosos sobre os rostos, queimando-os de relance ou em porções. De fato, esse mundo envolvido no acaso não permite pai nem mãe; é um mundo misterioso no qual o afetado pelos signos vive, em escala máxima, o enigma ou o drama do não saber: $D e$ onde poderia ter vindo essa alegria poderosa? Sentia que estava ligada ao gosto do chá e do biscoito, mas ultrapassava-o infinitivamente, não deveria ser da mesma espécie. De onde vinha? Que significaria? Onde apreendê-la? ${ }^{189}$. Suponha-se nisso, por exemplo, uma ideiaAdão; ao contrário de ela ser a ideia de uma perfeição, a perfeição adâmica, ela é a ideia do ser mais impotente e imperfeito do mundo, que não pode contar com uma determinação exterior nem com algo anteriormente conhecido para resolver as suas agruras, porquanto o primeiro homem só pode existir como um bebê que, distante da proteção familiar (pai e mãe), é entregue ou exposto acidentalmente a uma violência inédita (daí que, em qualquer experiência, a linguagem não possa ser outra coisa senão uma linguagem-bebê, ao contrário do que acontece em qualquer explicação, cuja linguagem é sempre uma espécie de linguagem-luz). Em resumo, eis o que aqui conceitualmente se destaca: os acasos não têm valor negativo, pois deles depende o pensamento (necessidade que deriva do acaso); mas a emergência de um sentido neles não é algo amigável, implicando a construção de teias primariamente flutuantes, fartas em rachaduras, sem alicerces nem colunas, como frouxas moradias sobre o abismo.

Os encontros intensivos envolvem poderosas sensações, fazendo com que um exercício interpretante se desenvolva, mas ainda a partir de diversas perspectivas, como invocação a medidas necessariamente multilineares, até que algo em definitivo se revele, torne-se um entendimento cabal. A compreensão, por exemplo, das marcas do tempo na aparência física das pessoas, aquelas que designam em algumas uma velhice prematura e aquelas que designam em outras uma juventude insistente, deve-se aos encontros alternados do herói com os signos da velhice e da juventude, tendo-se, porém, que a precipitação ou a dilação na idade aparente dos corpos nunca faz de homens e mulheres seres ilesos a uma defecção, a uma corrida sempre para o túmulo: Assim, o Tempo dispõe de trens expressos e especiais que

${ }^{189}$ R-CS, p. 51. 
levam a uma velhice prematura. Mas em trilhos paralelos circulam trens de regresso, quase tão velozes ${ }^{190}$. Tal intensidade nos encontros permite que certas questões possam ser vistas de quando em vez sob uma luz completamente nova, desatada pelas manobras que, para mais ou para menos, acompanham cada acontecimento. Que seja a verdade do amor o segredo de Sodoma (do amante) e Gomorra (da amada), essa norma absoluta, ainda que subterrânea, deve-se aos encontros eventuais do herói com os signos da homossexualidade; há no mínimo dois momentos notáveis que, correspondendo a encontros intensivos, ajudam a compor essa revelação: o primeiro está em Du côté de chez Swann, quando o herói, diante de uma janela, escondido entre as moitas, sem ser percebido, surpreende, absolutamente sem querer, a Srta. Vinteuil com uma amiga, numa perturbadora cena de intimidade, cujo ápice, não sem o teor das profanações sádicas que blasfemam a memória dos mortos, é o sugerido cuspe sobre o retrato do pai, o célebre músico, que há pouco falecera ${ }^{191}$; o segundo, mais decisivo, está em Sodome et Gomorrhe, quando o herói assiste, também de maneira involuntária e clandestina, a uma prodigiosa troca de signos entre Charlus e o alfaiate Jupien, com irretocáveis acordos de olhares, gestos e gemidos ${ }^{192}$. De outro modo, existem encontros intensivos que, embora envolvendo poderosas sensações, desembocam num fracasso total, como experiências nunca elucidadas. É o que ocorre, por exemplo, no episódio das três árvores, narrado em À l'ombre des jeunes filles en fleurs, quando o herói, estando nos arredores de Hudimesnil, vê três árvores à beira da estrada, à medida que o carro avança, devendo elas servir de pórtico a uma alameda, como ele acredita; de súbito, uma felicidade profunda, análoga àquela que lhe haviam dado os campanários de Martinville, invade-o, toma-o; mas, por incapacidade ou imperícia, ele não consegue jamais desenvolver o seu sentido: nunca soube o que aquelas árvores queriam me trazer e nem onde as conhecera ${ }^{193}$. Com efeito, por impotência, azar ou até mesmo preguiça, há sempre o risco de alguém perder as oportunidades dos bons encontros. Proust, num determinado momento, discorre sobre a situação daqueles que, não sem se renderem à facilidade das recognições, o que não os torna menos empolgados ou exaltados, passam ao largo das mais belas experiências, nada extraem das próprias impressões, esquivando-se de seus imperativos; na emergência do esplendor de um signo, resumem-se num estéril bravo! bravo! que não passa de uma homenagem ao objeto,

\footnotetext{
190 R-TR, p. 719.

191 R-CS, p. 136-140.

192 R-SG, p. 501-508.

193 R-MF, p. 547.
} 
confundindo, assim, o objeto com o signo que ele emite, além de não conseguirem esclarecer a natureza de suas próprias paixões: Julgam realizar-se gritando até perder a voz: "Bravo! Bravo!" após a interpretação de uma peça preferida. Mas tais manifestações não os obrigam a esclarecer a natureza de seu amor, que lhes permanece ignorada ${ }^{194}$.

Não se trata de voluntariamente tirar a pele, comer os nervos, lamber os ossos, chupar o tutano. A mão de ferro que busca imobilizar e esmigalhar um esquizoide, pressupondo, como fundamento, em si mesma, uma vontade prévia de pensar, um amor pela verdade e uma garantia do método, não mais nem menos do que por certas afinidades e comprometimentos, mão tirânica que outrora, erigindo verticalidades e se elevando, nem sequer esteve sub judice, derrete-se, talvez, em ácido. Já no pensamento dos poetas queimam e fervem os mais perversos e impetuosos fluxos corrosivos, regime de encenações, alargamentos ou correrias horizontais, refutando o dogmatismo metálico, o seu sistema de coordenadas, dinamismos e orientações, designando melhor, por isso, uma nova imagem do pensamento; poetas produzem em todo caso uma fissura, rasgam o guarda-sol que abriga os homens, destroem o firmamento por eles traçado, para que o caos livre e tempestuoso possa passar: primavera de Wordsworth, ou maçã de Cézanne, silhueta de Macbeth ou de Ahab ${ }^{195}$. O ato de pensar não decorre de uma simples possibilidade congênita, o exercício natural de uma faculdade, mas da pólvora de uma eventual explosão, estranheza pulsando, como flecha que ricocheteia, aqui, ali, ademais, em torno de um enigma por um instante interminável; é ela o que agride e medusa violentamente o pensamento, forçando-o a pensar, tirando-o de seu estupor: “impressões que nos forçam a olhar, encontros que nos forçam a interpretar, expressões que nos forçam a pensar" ${ }^{\prime 196}$. Proust fez bem, construindo em sua obra literária, tal qual do disparate de um narrador aracnídeo, uma imagem do pensamento que se opõe à da filosofia clássica de tipo racionalista, na aventura própria do involuntário, definindo de outro modo a busca da verdade: "Proust insiste muito nisso: a verdade nunca é o produto de uma boa vontade prévia, mas o resultado de uma violência no pensamento" ${ }^{197}$. Procura a verdade aquele que sofre, numa situação concreta, um ímpeto ou um terrorismo no pensamento, golpe que promove a discórdia das faculdades, cadeia de força e pavio de bomba: "Quem procura a

\footnotetext{
194 R-TR, p. 680-681.

195 QF, p. 239-240.

196 PS, p. 117 - PS(br), p. 89.

${ }^{197}$ PS, p. 24 - PS(br), p. 15.
} 
verdade é o ciumento que surpreende um signo mentiroso no rosto da amada. É o homem sensível quando encontra a violência de uma impressão. É o leitor, o ouvinte, quando a obra de arte emite signos, o que o forçará talvez a criar, como o apelo do gênio a outros gênios" 198 . A busca, hóspede de porosidades, impactos e transposições virais, zonas duras ou friáveis, cheias de corcovas, enquanto aprendizado de um homem de letras, em sua própria mobilidade, flutuabilidade e morosidade, em sua ideia-foto fortemente lambuzada por uma ideia-cinema, não realizada em dependência de um "eu" voluntário nem de uma decisão premeditada, diferenciando-se, então, do punho às unhas, da ortodoxia de uma mão-metal, decide-se, assim, involuntária, pela estupidez ou pancadas dos signos: "Ao invés do pensamento voluntário, tudo o que força a pensar, todo pensamento involuntário que só pode pensar a essência"199. Para a filosofia, isso se enche de importância: "É possível que a crítica da filosofia, tal como Proust a realiza, seja eminentemente filosófica. Que filósofo não desejaria construir uma imagem do pensamento que não dependesse mais de uma boa vontade do pensador e de uma decisão premeditada?"200.

Deleuze com Proust é Deleuze com Nietzsche; que se pergunte já de início “quem procura a verdade?"201, à parte do abstracionismo "que é o verdadeiro?", pois se trata de considerar um quem que a quer, mas segundo o que o força, deve-se a uma lógica mais ampla, estabelecida desde Nietzsche et la philosophie, no plano de uma subversão da pergunta clássica que é?: "A metafísica formula a questão da essência da seguinte forma: que é...?. Talvez nos tenhamos habituado a considerar óbvia essa pergunta; de fato, nós a devemos a Sócrates e a Platão. É preciso voltar a Platão para ver até que ponto a pergunta que é...? supõe um modo particular de pensar"202. Não sem a especificidade da complicação deleuzeproustiana, põe-se novamente, pois a questão do tipo quem? aponta não menos do que o modo de perguntar da complicação deleuze-nietzschiana, a tematização da própria forma de a filosofia se fazer perguntas, problema que tomaria rumo forte numa exposição de 1967: "Desde que nos perguntemos 'quem quer o verdadeiro, quando e onde, como e quanto?, temos a tarefa de consignar sujeitos larvares (o ciumento, por exemplo), e puros dinamismos espaço temporais (ora fazer surgir a 'coisa`em pessoa, numa certa hora, num certo lugar; ora acumular os indícios e os signos, de hora em hora, e segundo um caminho que jamais

\footnotetext{
198 PS, p. 119 - PS(br), p. 91.

199 PS, p. 121 - PS(br), p. 93.

200 PS, p. 122 - PS(br), p. 93.

201 PS, p. 23 - PS(br), p. 14.

202 NF, p. 51.
} 
acaba)"203. A forma de pergunta que anima a tradição reclamada platônica, embora em Platão ela não fomente senão os primeiros diálogos chamados "aporéticos", visto que toma outras formas quando a dialética platônica se desenvolve (“quem?", no Político; “quanto?”, no Filebo; “onde e quando?", no Sofista; “em qual caso?”, no Parmênides), é a forma que é?, pergunta por excelência metafísica, visando uma essência: “que é o belo?", “que é o bem?", “que é a justiça?” etc. Mas não está assegurado que questões do tipo que é? sejam boas questões; na verdade, o seu privilégio na filosofia se revela confuso e duvidoso, já que questões do tipo dramático quem?, quanto?, como?, onde? e quando? constituem a forma de questão principal na história da filosofia (talvez, com exceção, diz Deleuze, provocando o protesto de Alquié, da obra de Hegel). Mesmo quando os filósofos levantam a questão que é?, fazem-na como uma maneira cômoda de se exprimirem, no quadro de uma questão mais profunda, de um como?. Ainda assim, pergunte-se, não teria a questão do tipo que é?, no fundo, uma função reguladora, precedendo e dirigindo o que está em pauta nas outras questões, pressupondo-as somente como apêndices, para que ela mesma, afinal, fosse resolvida? - como defende Breton: "É para responder à questão que é? que me proponho as outras questões"204. Deleuze com Nietzsche responde que, ao perguntar quem? ou de qual ponto de vista?, a pretensão não é completar a questão que é?, mas exatamente denunciar a forma dessa questão e de todas as respostas possíveis; os dois tipos de questão demandam, portanto, métodos inconciliáveis: "Quando pergunto que é?, suponho haver uma essência atrás das aparências, ou, pelo menos, algo último atrás das máscaras. O outro tipo de questão, ao contrário, descobre sempre outras máscaras atrás de uma máscara, deslocamentos atrás de todo local, outros 'casos' encaixados num caso"205. À questão quem?, que encara o movimento das forças reais, pois neste caso o que está em cena é a forma pela qual uma coisa pode se tornar, por exemplo, bela, boa ou justa, responde-se com uma perspectiva impessoal, porque não se trata de uma psicologização filosófica; não remete, assim, a um indivíduo, o que reduziria o pensar a uma simples consciência, mas a um acontecimento, a um "o que é que se passou?” ou a um "o que é que vai se passar?” (e “onde?”, “quando?”, “como?”), o pensamento em suas múltiplas dimensões, sob o traço da violência que o funda, não tornado mais concreto por se encarnar num sujeito ou agente específico; de fato, na melhor

\footnotetext{
203 ID, "O método de dramatização", p. 134.

204 ID, "O método de dramatização", p. 151.

205 ID, “O método de dramatização", p. 152.
} 
complicação deleuze-nietzschiana, remete às forças, ou, na melhor complicação deleuzeproustiana, remete aos signos: em toda parte é um quem segundo o que o força.

$\mathrm{O}$ aspecto crítico dessas complicações, que tem sempre como inimiga a ideia de que pensar é um ato natural ao pensamento e que se pensa quando se reconhece, encontra em Différence et répétition, muito afeita ao que aparece na primeira parte de Proust et les signes, uma formulação incisiva e econômica: "Há no mundo alguma coisa que força a pensar. Este algo é o objeto de um encontro fundamental e não de uma recognição"206. As ideias anestésicas da inteligência voluntária, não nascidas de encontros intensivos, resolvidas, ao contrário, num pacifismo de opiniões que, comunicando-se "sob o efeito de uma boa vontade comum"207, beatificam acordos sobre a significação das coisas e das palavras, noções confortavelmente instaladas numa língua bem comportada, impondo-se como empresa de reconhecimento, recorrendo, sob a forma de uma parafernália de slogans, a um suposto cadastro que tudo de antemão triou e classificou, atingem em sua gratuidade apenas verdades arbitrárias e abstratas que não perturbam, pressupondo em sua ferragem de dedos, além da divindade do método, o caráter bicéfalo do pensar verdadeiro/verdadeiramente, ambos confinados num suposto desejo natural de pensar. Contradize-as bem o herói, pensa Deleuze com Proust, em passagens como esta: As ideias formadas pela inteligência pura só têm uma verdade lógica, uma verdade possível, sua escolha é arbitrária ${ }^{208}$. Conservando o a priori de categorias requentadas, elas combinam e mobilizam previamente os encontros, organizandoos nos limites de suas tesouras; suas significações explícitas e convencionais nunca são profundas, pois guardam a forma da representação e o discurso do representante ("todo mundo sabe", "ninguém pode negar"); hipnóticas, recozinham o conformismo viciado no senso comum e no bom senso, beirando em seus jardins domésticos o silêncio das ovelhas sob o orvalho, na medida em que lhe bastam os frenesis dos atos de recognição. À busca que não se faz por colisões e estrondos, o acaso dos encontros e a pressão dos signos, falta a marca da necessidade, a marca de sua autenticidade ${ }^{209}$; seus engenhos, tomados como sensatos, com os significados que neles se decidem, não são senão a forma de uma esterilidade, como se pode repercutir, não sem os espinhos de seu meio expressivo, o Zaratustra de Nietzsche neste fragmento, situado num trecho todo adequado: "Mas deverá ser esta a vossa maldição, ó

\footnotetext{
206 DR, 231.

${ }^{207}$ PS, p. 116 - PS(br), p. 89.

208 R-TR, p. 672.

209 R-TR, p. 671.
} 
imaculados buscadores do puro conhecimento: que nunca dareis à luz coisa alguma, ainda que estejais grandes e pejados no horizonte!"210. A Recherche toca no essencial, sob a forma das forças efetivas que agem sobre o pensamento, retorcendo-se em aventuras mais estranhas, as algazarras dos encontros intensivos, que provocam, por exemplo, uma alógica alegria: mesmo que o simples sabor de uma madeleine não pareça, logicamente, conter os motivos desse júbilo ${ }^{211}$. É que, em qualquer caso, só se pensa quando signos berram ou mordem: o que é primeiro no pensamento é o arrombamento, não pela extensão pura e simples de um racionalismo; nada supõe filosofia, "tudo parte de uma misosofia"212. Dá-se um campo no qual os afetos se condensam e se encarnam em ideias, um transbordamento do virtual enquanto eclode no atual: "aquilo que só pode ser sentido (o sentiendum ou o ser do sensível) sensibiliza a alma, torna-a 'perplexa', isto é, força-a a colocar um problema, como se o objeto do encontro, o signo, fosse portador de problema - como se ele suscitasse problema"213. Isso significa que, considerado como signo, o culpado das sensações não é o ser sensível, mas o ser do sensível: não o dado, mas aquilo que faz com que o dado seja dado. Experiências desse tipo implicam a intervenção de um precursor sombrio, não inscrito nas malhas de um ambiente simbólico no qual o seu sentido esteja dado ou sugerido de antemão; são ressonâncias e movimentos forçados o que dele decorre: um teatro especial de virtualidades, uma expressividade de ideias. Pensa-se, mas pensa-se por força de diferenciais irredutíveis tanto ao voluntarismo pensante quanto à decodificação habitual de dados exteriores: irredutibilidade ao dogmatismo vulgar, que se destina a "sempre preencher o que separa", e ao empirismo vulgar, que deixa exterior o "separado" 114 . O pensamento começa sem substrato primeiro, em imanência produtiva com uma multiplicidade de relações; está enfim envolvido por intensidades que não cessam de destituir toda a identidade: pensar outramente, instalar-se entre, crescer pelo meio, erva daninha.

Buscar a verdade é interpretar, decifrar, traduzir o sentido de um signo; é caso de produção, involuntariamente disparada em cada assalto eventual, não havendo sentido a ser procurado aquém ou além do acontecimento premente, já que todas as coisas implicam sentidos dependentes das forças circunstanciais que insistem nelas. Por um lado, concebe-se o pensamento como sinestésico, o que significa dizer que, nas experiências, há uma confluência

\footnotetext{
${ }^{210}$ Friedrich Nietzsche (2005b, p. 154).

${ }^{211}$ R-TR, p. 667.

212 DR, p. 230

213 DR, p. 232.

${ }^{214}$ DR, p. 278.
} 
entre os modos de sentir e pensar (um som ou uma nota, para uma cor; um aroma ou um gosto, para um lugar); mas de nada serviria acreditar no a priori de certas categorias pensantes, porque o signo não é de forma alguma uma besta-fera a ser exorcizada por pressupostos: “A verdade não é descoberta por afinidade nem boa vontade, ela se trai por signos involuntários” ${ }^{215}$. Ainda a crença céltica a qual se refere Proust, baseada na hipótese de liberar as almas prisioneiras das pessoas que morreram, depende de muita eventualidade: caso alguém passe perto da árvore que prende as almas, caso alguém entre na posse do objeto que prende as almas, caso alguém reconheça as almas presas, caso o encanto se quebre etc ${ }^{216}$. Por outro lado, o sentido se encontra enrolado, envolvido ou implicado no signo exatamente do ponto de vista da sua não preexistência, exigindo explicações, desenvolvimentos: "Traduzir, decifrar, desenvolver são a forma da criação pura"217. É ele um efeito produzido segundo os elementos presentes em ausência (encontrados, não reconhecidos), na substituição de uma hermenêutica parcialmente decodificadora por uma pragmática inteiramente sensível, no deslocamento da simples prescrição pela pura performatividade, tornando-se o aprendiz sempre o "egiptólogo" de alguma coisa, não ileso às reviravoltas interpretantes que vez a vez incluem equívocos ou mal-entendidos. Como na perspectiva nietzschiana de Erfindung (invenção), que desloca a de Ursprung (origem), essa busca da verdade não se faz, portanto, pela concepção do verdadeiro como um universal abstrato, o que proveria um santuário para os valores estabelecidos, reforçando-se, deste modo, em regiões viciadas, apenas para reafirmar sentidos já previstos e condecorados - toda aquela prática doméstica que faz do hermeneuta, seja o sábio antigo, venerado pelo domínio fundante do sagrado, seja o pensador hodierno, venerado pelo bom manejo dos métodos, um excelente colecionador dos valores em curso, um obediente funcionário do senso comum. Fora tanto do paradigma lógico da verdade quanto da matriz doxológica deste paradigma, buscar a verdade é sempre uma construção interpretante: "Erramos, por acreditarmos nos fatos: só há signos. Erramos, por acreditarmos na verdade: só há interpretações" ${ }^{218}$. Não se trata de veridismo, mas de criatividade verídica, pois não há verdade que, antes de ser verdade, não seja a efetuação de um sentido ou a realização de um valor: verdade que não é preexistente, mas produto de uma interpretação experiencial no tempo; verdade que não se dá, mas se trai; verdade que depende do sentido

\footnotetext{
215 PS, p. $24-$ PS(br), p. 15.

${ }^{216}$ R-CS, p. 51.

${ }^{217}$ PS, p. 119 - PS(br), p. 91 .

${ }^{218}$ PS, p. $112-$ PS(br), p. 86.
} 
produzido, não o contrário; pensamento que, em última instância, é verdadeiro segundo a verdade que sabe $\operatorname{produzir}^{219}$. Na segunda parte de Proust et les signes, diz-se claramente: “A Recherche é a produção da verdade procurada. Não há exatamente a verdade, mas ordens de verdade, como ordens de produção" 220 . Em termos decisivos, a questão assim se apresenta em Différence et répétition: "A verdade, sob todos os aspectos, é caso de produção, não de adequação. Caso de genitalidade, não de inatismo nem de reminiscência"221. Aquele velho commerce entre o pensamento e as formas-estado, no qual estas, por meio de inúmeras estrofes de controle, fornecem os acordes para que o pensamento se faça, enquanto o pensamento, ungido talvez por dívida, leal e generosíssimo, trata de simplesmente legitimálas, sem causar a alguém o menor embaraço, porque, afinal, recebe aí a venerável insígnia de pensamento sensato, ocultando, porém, o trabalho das forças que o determinam como tal, é apenas o modo moral pelo qual a verdade aparece como uma criatura bonachona e amiga de comodidades: "O signo da recognição celebra esponsais monstruosos em que o pensamento 'reencontra' o Estado, reencontra a 'Igreja', reencontra todos os valores do tempo que ela, sutilmente, fez com que passassem sob a forma pura de um eterno objeto qualquer, eternamente abençoado" 222 .

No aprendizado dos signos, o tempo é uma condição necessária: "Procurar a verdade é interpretar, decifrar, explicar. Mas esta 'explicação` se confunde com o desenvolvimento do signo em si mesmo. Por isso a Recherche é sempre temporal e a verdade, sempre uma verdade do tempo"223. A cada um dos quatro tipos de signos corresponde uma estrutura de tempo privilegiada, como quatro diferentes linhas de tempo, subordinadas a duas categorias mais gerais: tempo perdido (tempo que se perde e tempo perdido); tempo redescoberto (tempo que se redescobre e tempo redescoberto). O tempo perdido é um tempo que se perde, como na expressão "perder tempo", correspondendo especialmente aos signos mundanos, quando as ninharias da vida social impedem ou prejudicam, por exemplo, o trabalho do herói em sua literatura (a verdade desses signos aparece no momento em que o "eu" que lhes interpreta se modifica, passa por uma maturação); mas também é um tempo perdido no estado mais puro,

\footnotetext{
${ }^{219}$ ID, “Sobre Nietzsche e a imagem do pensamento", p. 175.

220 PS, p. 178 - PS(br), p. 140.

221 DR, p. 252.

222 DR, p. 225.

${ }^{223}$ PS, p. 25 - PS(br), p. 16.
} 
correspondendo especialmente aos signos amorosos, quando o amor antecipa, de certo modo, a sua alteração e anulação, não deixando de trazer consigo a própria destruição, ensaiando o momento de ruptura ou o fim (a verdade desses signos aparece no momento em que o "eu" que amava já não existe mais). O tempo redescoberto é um tempo no âmago do tempo perdido, no sentido de "tempo que se redescobre", correspondendo especialmente aos signos sensíveis, pois estes, embora sejam signos de transição, ainda insuficientes, apontando a necessidade de seu ultrapassamento, chegam a revelar uma imagem da eternidade, formam já um começo da arte (a verdade desses signos aparece pelo poder que têm de ressuscitar, pela memória involuntária, ou suscitar, pela imaginação, o "eu" que corresponde ao seu sentido); mas também é um tempo redescoberto no estado mais puro, no sentido de "tempo original absoluto", verdadeira eternidade que se afirma na arte, tempo primordial no qual todos os tempos se acham complicados, não desdobrados: “Aí está o sentido da expressão 'tempo redescoberto`. O tempo redescoberto, em estado puro, está contido nos signos da arte"224. A despeito de cada signo ter uma dimensão temporal privilegiada, cada um participa de modo desigual de várias linhas de tempo, excetuando-se os signos artísticos, que só se desenvolvem no tempo original absoluto; o pluralismo multiplica as combinações, pois uma mesma linha mistura desigualmente espécies distintas de signos: “O tempo que se perde prolonga-se no amor e mesmo nos signos sensíveis. O tempo perdido já aparece na mundanidade e subsiste ainda nos signos da sensibilidade. O tempo que se redescobre reage, por sua vez, sobre o tempo que se perde e sobre o tempo perdido" ${ }^{225}$. O caso mais emblemático de combinações irregulares é o da botina que faz o herói sentir a morte da avó: a princípio, ele não difere de outros casos sensíveis, mas o seu desenvolvimento implica um tempo perdido para sempre, com o sentimento agudo e sofrido, ao invés de um tempo que se redescobre ou alguma imagem da eternidade. As linhas de tempo valem por si mesmas, como se houvesse no tempo séries diversas e paralelas $^{226}$; no entanto, isso não impede que haja entre elas uma hierarquia. Quando se ascende na ordem dos signos, uma linha superior de tempo recupera o que estava perdido na linha inferior, recobrando a verdade que a outra perdeu: "tudo acontece como se as linhas do tempo se partissem, encaixando-se umas nas outras" 227 , sendo a relação do signo com o sentido cada vez mais estreita. É no tempo original absoluto da arte, que abarca de uma

\footnotetext{
${ }^{224}$ PS, p. $59-$ PS(br), p. 43-44.

${ }^{225}$ PS, p. 34-35-PS(br), p. 23.

${ }^{226} \mathrm{R}-\mathrm{SG}, \mathrm{p} .625$.

${ }^{227}$ PS, p. 108 - PS(br), p. 83.
} 
só vez todas as séries, que o herói compreende a importância dos outros três tempos em seu aprendizado (do tempo que se perde na vida mundana, do tempo perdido nos amores fracassados ou desfeitos e do tempo que se redescobre nas ambivalentes experiências sensíveis). As linhas de tempo são, portanto, verdadeiras linhas de aprendizado, convergindo para a arte, que transforma o tempo perdido em tempo redescoberto.

Essa engenharia deleuze-proustiana do tempo pode parecer estrambótica, mas ela se justifica nos próprios quadros do sistema de pensamento que nela se desenha (quatro tipos de signos, em quatro linhas de tempo, segundo as faculdades que os desenvolvem); mais além, não é impróprio topar, por assim dizer, com o encontro fortuito de uma máquina de costura e um guarda-chuva quando se pensa nos vários modos de tempo que se apresentam nas obras do filósofo, modos que evocam, não raramente, certo desregramento, como tempos descentrados, aberrantes, paradoxais; num extrato, eis alguns fragmentos do tempo nas obras deleuzianas, na extensa síntese de Pelbart: por exemplo, "o presente como síntese passiva subrepresentativa, ou contemplação contraente (Plotino, Hume)"; por exemplo, "o passado como Memória ontológica, Memória-mundo, Cone Virtual (Bergson)”; por exemplo, "o futuro como retorno seletivo que rejeita Sujeito, Memória, Hábito (Nietzsche)”; por exemplo, “a oposição Aion/Cronos (estoicos)"; por exemplo, "o tempo do Acontecimento (Péguy, Blanchot)"; por exemplo, "o Intempestivo (Nietzsche)"; por exemplo, "o tempo como 'defasagem' (Simondon)”; por exemplo, “a Cesura e um tempo que já não 'rima' (Holderlin)"; por exemplo, "o tempo perplicado, o tempo puro ou reencontrado da arte (Plotino, Proust)"; por exemplo, "o tempo liberado de sua subordinação ao movimento (Kant versus Aristóteles)"; por exemplo, "o tempo como Diferença, ou como Outro (Platão contra Platão)"; por exemplo, “o tempo como potência, não como Finitude (Bergson versus Heidegger)"; por exemplo, "o tempo como Fora (Blanchot, Foucault)"228. No Proust et les signes, começando pelo fato de que signo e sentido se relacionam no tempo, o que está em pauta não é apenas o problema do pluralismo temporal proustiano, a dinâmica cinematográfica dos cruzamentos laterais, de uma série a outra, de uma periodicidade a outra, tempo galáctico, indo e vindo, não sucessivo, não homogêneo, não linear ou não uniforme, questão bastante visitada pela fortuna crítica, mas o problema desse pluralismo temporal fotocinematograficamente conjugado ao problema do tempo original absoluto da arte, ligação que efetivamente caracteriza o aprendizado: entre as séries baixas (tempo que se perde, tempo

${ }^{228}$ Peter Pál Pelbart (2000b, p. 88). 
perdido e tempo que se redescobre), há um desnível garantido ou discernido pelo estatuto do tempo redescoberto, que as compreende; cada série tem, assim, uma dupla relação, com os níveis imediatamente inferiores ou superiores e com o nível absoluto do tempo artístico; mas isso só se torna evidente quando, no campo desmaterializado e espiritualizado da arte, descobre-se o tempo primordial, idêntico à eternidade, que arrasta consigo todos os outros, conferindo-lhes um caráter de verdade que de outra forma não conseguiriam alcançar. É que o mundo envolvido da arte é sempre um começo do Mundo em geral, o que igualmente corresponde ao nascimento do Tempo, como se vê no caso da famigerada sonata, quando Proust disserta sobre a conversação entre o piano e o violino: Era como no começo do mundo, como se só existissem eles dois sobre a terra, ou melhor, naquele mundo fechado a tudo o mais, construído pela lógica de um criador, e onde só os dois existiriam para todo o sempre: aquela sonata $^{229}$. Deleuze com Proust recorre a alguns neoplatônicos que se serviam da palavra "complicação" para designar essa eternidade, o estado originário que precede todo desenvolvimento, todo desdobramento, toda explicação, o estado complicado do tempo: “A eternidade não lhes parecia a ausência de mudança, nem mesmo o prolongamento de uma existência sem limites, mas o estado complicado do tempo em si mesmo (uno ictu mutationes tuas complectitur) ${ }^{\text {"230 }}$. Nesse sentido, o herói proustiano tem revelações do tempo original, o extratemporal da obra de arte (que não se confunde com as experiências breves e fortuitas da memória involuntária), enquanto tempo enrolado, com todas as suas dimensões imbricadas na própria essência artística, o que permite entender por que a arte é o único meio de redescobrir o tempo: "O que a arte nos faz redescobrir é o tempo tal como ele se encontra enrolado na essência, tal como ele nasce no mundo envolvido da essência, idêntico à eternidade. $\mathrm{O}$ extratemporal de Proust é esse tempo no estado de nascimento, e o sujeito-artista que o redescobre"231. A essa questão se junta outra, bastante decisiva nessa filosofia: não obstante as séries, encontrando cada uma a sua verdade, resolvam-se no tempo redescoberto, este não as reúne numa unidade ou totalidade, porque, como se afirma depois, em "A máquina literária", o tempo é justamente "a instância que impede o todo" ${ }^{232}$. Isso significa que, no problema do tempo, insiste ou subsiste o problema do par uno-múltiplo, o que exigirá adiante essa nova

\footnotetext{
229 R-CS, p. 276-277.

${ }^{230}$ PS, p. 58 - PS(br), p. 43.

231 PS, p. 59 - PS(br), p. 44.

232 PS, p. 193 - PS(br), p. 153.
} 
compreensão: uno como efeito do múltiplo, unidade posterior, como um trecho composto à parte.

No aprendizado, a lógica que se fomenta, aquela para a qual cada sensação oferece necessidade, é em diversos momentos rudimentar, desprovida, desprevenida. Que o intérprete em todos os campos de signos sofra decepções, que a boa interpretação esteja em perigo, que as pegadas por vezes se dissipem ou se desvaneçam, dificultando o aprendizado como marcas d’água inundadas por mais água, mesmo havendo nelas uma espécie de alma cativa se esforçando por abrir a tampa, deve-se a duas crenças que deturpam a busca da verdade: em primeiro lugar, o objetivismo, que é atribuir ao objeto, pelo lado do prazer ou do gozo imediato, o segredo do signo que ele emite, rendendo-lhe uma homenagem, confundindo, pois, o sentido do signo com o objeto que ele designa; em segundo lugar, o subjetivismo, que é interpretar o signo meramente a partir de um jogo de associações de ideias, esforçando-se por atenuar a decepção objetiva numa compensação subjetiva, como se o suposto elemento oculto ou latente pudesse ser encontrado nos estados transitórios do sujeito da percepção. É verdade que o objetivismo se faz de início como a tendência natural da percepção consciente, amparado pelas facilidades das recognições, relacionando o objeto com o signo que ele emite; na experiência com a madeleine, por exemplo, o herói, tomado por uma alegria incomum, inclina-se sobre a xícara de chá e bebe mais um pouco, como se o próprio objeto pudesse revelar o mistério do signo; na experiência com as pedras do calçamento, de forma semelhante, ele procura refazer o movimento do passo, entre uma laje e outra, como se a simples repetição do gesto físico ou material pudesse dar resposta à felicidade que o invade; com efeito, a percepção deseja o objeto, assim como a inteligência deseja a objetividade: “Ao mesmo tempo que a percepção se dedica a apreender o objeto sensível, a inteligência se dedica a apreender as significações objetivas. Pois a percepção acredita que a realidade deve ser vista, observada; mas a inteligência acredita que a verdade deve ser dita e formulada" ${ }^{\text {233. }}$. O objetivismo leva a decepções, não poupando nenhuma espécie de signo: na mundanidade, afiança-se que os que emitem signos são também os que os compreendem e deles detêm o código, como ocorre em relação à duquesa de Guermantes, que aparece ao herói, no começo, antes de conhecê-la, com a auréola do prestígio, devendo ela possuir, ele acredita, o sentido de seu próprio sobrenome; no amor, pensa-se que ao ser amado pertence aquilo que parece tão único, sendo preciso então lhe confessar o sentimento, render-lhe um culto, como ocorre nos

${ }^{233}$ PS, p. 40 - PS(br), p. 28. 
primeiros amores, especialmente com Gilberte; nas impressões ou qualidades sensíveis, crê-se inutilmente que o objeto revela o enigma do signo, como se vê no caso da madeleine e das pedras do calçamento; na arte, presume-se que a chave está nos objetos a descrever, nas coisas a designar, nas personagens ou nos lugares a observar, como é possível se ter por ávidas pretensões objetivistas - que são dignas, no entanto, das mais severas críticas de Proust, contra Sainte-Beuve, contra os Goncourt, contra a arte realista ou popular. A literatura, a pintura e a música não escapam do objetivismo: "E mesmo quando vencemos as ilusões objetivistas na maior parte das áreas, elas subsistem ainda na Arte, em que continuamos a crer que é preciso saber escutar, olhar, descrever, dirigir-se ao objeto, decompondo-o e triturandoo para dele extrair uma verdade" 234 .

Em cada campo de signos, a desilusão ocorre quando o objeto não revela o segredo que se esperava. Como tentativa de remediar os desapontamentos, cai-se muitas vezes na ilusão oposta, o subjetivismo, que é a substituição dos valores objetivos pelas associações de ideias: "Cada linha de aprendizado passa por esses dois momentos: a decepção provocada por uma tentativa de interpretação objetiva e a tentativa de remediar essa decepção por uma interpretação subjetiva, em que reconstruímos conjuntos associativos" ${ }^{235}$. Em relação à duquesa de Guermantes, por exemplo, quando o herói finalmente a vê e depois vem a conhecê-la, percebendo que ela não detém o sentido de seu sobrenome, ele se torna pessoalmente sensível, por compensação, a signos menos profundos, porém mais apropriados ao charme da mulher, graças ao jogo de associações de ideias que ela desperta: Que a Sra. de Guermantes fosse igual às outras mulheres, isto para mim fora a princípio uma decepção; agora, por reação, e com a ajuda de tantos bons vinhos, era um deslumbramento ${ }^{236}$. Tal mecanismo de passagem do objetivismo ao subjetivismo é particularmente evidente no exemplo do teatro: indo ouvir a atriz Berma, procurando decifrar o seu talento, o herói identifica-a com a própria Fedra, por conta de certa entonação inteligente, de admirável justeza; logo em seguida, contudo, decepciona-se, por ser essa entonação apenas engenhosa ${ }^{237}$; a desilusão objetiva lhe sugere recorrer a associações que não estão na Berma nem em Fedra, como a interpretação subjetivista, sugerida por Bergotte, de que determinado gesto da Berma evoca o de uma estatueta arcaica, certamente, porém, nunca vista nem

\footnotetext{
234 PS, p. 43 - PS(br), p. 30.

${ }^{235}$ PS, p. 47-48 - PS(br), p. 34.

236 R-CG, p. 434.

${ }^{237}$ R-MF, p. 436.
} 
pensada pela atriz ou por Racine. Salta-se facilmente de uma decepção objetiva para uma compensação subjetiva, na qual cada intérprete constrói uma espécie de "museu particular", mesmo em relação à arte, tornada deste modo um simples elo na cadeia das associações: Swann aprecia como nunca Giotto ou Botticelli, pois os descobre, assim, peculiarmente, no traçado do rosto da cozinheira ${ }^{238}$ ou da mulher amada ${ }^{239}$; em algum momento, acha bela a música de Vinteuil, pois ela lhe evoca um passeio no Bois de Boulogne ${ }^{240}$. Ainda que por razões diversas, o subjetivismo também decepciona, tornando mesmo a arte uma ideia entre outras: "Então, somos capazes de pressentir que o momento da compensação continua insuficiente em si mesmo e não nos dá uma revelação definitiva"241. É verdade que esses equívocos objetivistas e subjetivistas, além de serem etapas no aprendizado, podem ter por agora uma razão compreensível: qualquer signo, embora sendo mais profundo do que o objeto que o emite, ainda se liga ao objeto e, embora sendo mais profundo do que o sujeito que o interpreta, ainda se liga ao sujeito.

Entretanto, o que existe além do objeto e do sujeito? - é o que se pode perguntar, adentrando-se melhor na questão das essências, noção muitíssimo corrente na Recherche, mas que, ao transitar na complicação deleuze-proustiana, não obstante possa de pronto surpreender, esboça validade nos contornos de uma filosofia da diferença. Para Deleuze com Proust, o próprio exemplo da Berma, sobre o qual o narrador-herói avidamente se alonga, oferece uma resposta: "Fedra é um papel a ser representado e a Berma se integra nesse papel. Não no sentido em que o papel seria ainda um objeto, ou algo subjetivo. Ao contrário, é um mundo, um meio espiritual povoado de essências"242. A atriz se serve de sua voz, na qual não subsiste um só resíduo de matéria inerte e refratária ao espírito ${ }^{243}$, assim como se serve de seus braços, do seu corpo; os gestos, em vez de testemunharem meros esforços ou acrobacias musculares, constituem um "corpo transparente" que refrata, mais propriamente, uma essência, uma Ideia. Da mesma forma, o músico se serve de um piano, mas as notas musicais são apenas a aparência sonora de uma entidade espiritual: "Essências ou ideias são o que revela cada signo da pequena frase de Vinteuil. Isso é o que dá à frase sua existência real,

\footnotetext{
238 R-CS, p. 77.

239 R-CS, p. 183.

${ }^{240}$ R-MF, p. 411-412.

${ }^{241}$ PS, p. 48 - PS(br), p. 34.

242 PS, p. 49 - PS(br), p. 35.

${ }^{243}$ R-CG, p. 44.
} 
independentemente dos instrumentos e dos sons que a reproduzem ou a encarnam mais do que a compõem"244. Isso significa que o campo desmaterializado e espiritualizado da arte revela "essências", que constituem o seu sentido, tornando-se o intérprete capaz de exceder tanto as propriedades do objeto quanto os estados da subjetividade, caracterizando-se a boa interpretação, neste caso, como a perfeita unidade entre signo e sentido: “Além dos objetos designados, além das verdades inteligíveis e formuladas, mas também além das cadeias de associação subjetivas e de ressurreições por semelhança ou contiguidade, há as essências, que são alógicas ou supralógicas" 245 . Existe um platonismo em Proust, que invoca comumente as essências como Ideias platônicas, conferindo-lhes uma realidade independente (nas questões artísticas, nas impressões sensíveis, nas experiências amorosas e até mesmo nos entreatos que adornam a vida mundana); é assim que, no caso da Berma, tenta-se captar a essência do talento da atriz e, a propósito de Vinteuil, circula-se muitas vezes em torno da essência da frase musical. O problema é que, com relação ao platonismo, sucedem-se também, segundo Deleuze com Proust, muitas diferenças, todas elas acarretadas, fundamentalmente, pela dinâmica sem pressupostos que caracteriza a nova imagem do pensamento, o acaso dos encontros e a necessidade de interpretação; de modo preciso, as essências proustianas não são anteriores nem estrangeiras ao aprendizado, sendo ao mesmo tempo a coisa a traduzir (signo) e a própria tradução (sentido): "Não há Logos, só há hieróglifos. Pensar é, portanto, interpretar, traduzir. As essências são, ao mesmo tempo, a coisa a traduzir e a própria tradução, o signo e o sentido" 246 . O que se delineia até a revelação delas na arte é uma “dialética ascendente" (mundanos $\rightarrow$ amorosos $\rightarrow$ sensíveis $\rightarrow$ artísticos); desde os níveis mais baixos, entre revelações e decepções, vacilando o mundo na corrente do aprendizado, há qualquer coisa que se pressente, um pressentimento, como pré-compreensão; na medida em que se vai chegando ao domínio artístico, especialmente no contexto dos signos sensíveis, a relação do signo com o sentido se torna cada vez mais íntima, como progressos efetivos do aprendizado, aproximando-se das essências, embora ainda de modo impreciso e obscuro; enfim, atinge-se a revelação das essências no âmbito da arte (literatura, pintura, música), como a última palavra do aprendizado ou a revelação final, o que pode englobar, é claro, a própria obra que sorrateiramente se constrói: “Os signos mundanos, os signos amorosos e mesmo os signos sensíveis são incapazes de nos revelar a essência: eles nos aproximam dela,

\footnotetext{
${ }^{244}$ PS, p. $53-\mathrm{PS}(\mathrm{br})$, p. 39.

${ }^{245}$ PS, p. 50 - PS(br), p. 35-36.

${ }^{246}$ PS, p. 124 - PS(br), p. 95.
} 
mas nós sempre caímos na armadilha do objeto, nas malhas da subjetividade. É apenas no

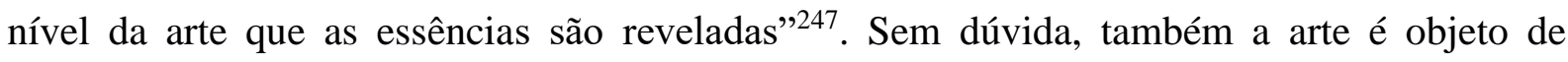
aprendizado, podendo passar, como já foi dito, pela tentação objetivista e pela compensação subjetivista, equívocos interpretantes que não poupam nenhuma espécie de signo; todavia, vêse de qualquer forma o seu privilégio absoluto, que se exprime de várias maneiras: a imaterialidade do signo artístico (matéria espiritualizada), a essencialidade absoluta do sentido (essência), a adequação entre signo e sentido (signo como estilo, sentido como essência).

Deleuze com Proust é Deleuze com Leibniz, pelo menos num ponto, tomando as essências reveladas na arte como mônadas, unidades irredutíveis e fechadas, sem portas nem janelas para a aeração, cada qual contendo o mundo inteiro em seu fundo sombrio, como pátrias desconhecidas, libertas de toda determinação exterior: "as essências são verdadeiras mônadas, cada uma se definindo pelo ponto de vista através do qual ela exprime o mundo, cada ponto de vista remetendo a uma qualidade última no fundo da mônada"248. Bogue assim o explica: "Leibniz diz frequentemente que as várias perspectivas das mônadas são como visualizações variadas de uma mesma cidade, cada uma fornecendo uma visão diferente de uma mesma entidade" ${ }^{249}$. É que a noção de essência que está sendo tematizada é uma essência-diferença, tal como revelada na obra de arte, diferença última absoluta; com Platão, resíduo de contraponto com a idealidade das essências (sem a universalidade platônica que as pressupõe como chegada desde o ponto de partida); com Leibniz, toda a individualidade de cada essência como um ponto de vista singular (sem a restauração leibniziana de uma unidade ou totalidade prévia entre as mônadas). Não se trata de uma diferença empírica, sempre extrínseca, assim, entre duas coisas ou dois objetos, diferença então reduzida à experiência comum; como diz Proust, o mundo de diferenças não existe na superfície da terra nem no mundo elegante ${ }^{250}$; trata-se, ao contrário, de uma diferença interna, no âmago de um sujeito, constituindo o ser, conforme a pista deixada em Le temps retrouvé, quando Proust se refere ao estilo artístico: É a revelação, impossível pelos meios diretos e conscientes, da diferença qualitativa que existe na maneira como nos surge o mundo, diferença que, se não houvesse a arte, ficaria sendo o segredo eterno de cada $\mathrm{um}^{251}$. A superfície da terra ou o mundo elegante (mundo exterior) é apenas a projeção ilusória dos diferentes mundos expressos por sujeitos,

\footnotetext{
247 PS, p. 50 - PS(br), p. 36.

248 PS, p. 54 - PS(br), p. 40.

${ }^{249}$ Ronald Bogue (1989, p. 39).

${ }^{250}$ R-AP, 208.

251 R-TR, p. 683.
} 
mundos que não existem fora dos sujeitos que os exprimem: cada um exprime o mundo de certo ponto de vista, sendo este ponto de vista a própria diferença; cada um exprime, pois, um mundo absolutamente diferente. Mantém-se, porém, bastante razoável a pergunta: não seria esse ponto de vista o refúgio oculto da subjetividade, um estado psíquico que, no fundo, não se permite como "essencial", sendo apenas o índice subjetivo da interpretação? A resposta exige não confundir mundo expresso e sujeito, sob o risco de se tomar a essência pela existência: o mundo expresso não existe fora do sujeito que o exprime, mas ele é expresso como a essência do Ser (ou da região do Ser) que se revela ao sujeito, essência que não é a do próprio sujeito; em outras palavras, o ponto de vista superior pelo qual se exprime o mundo não se confunde com quem nele se coloca. Distingue-se, portanto, nessa análise très ontologique, essência e sujeito, o que implica dizer: a relação entre sujeito e essênciadiferença não é do tipo sujeito e objeto; o sujeito não explica a essência, é a essência (pátria desconhecida) que se enrola no sujeito; mais do que isso, é a essência não subjetiva que constitui a subjetividade (essência individualizante, superior ao indivíduo), inerente às múltiplas expressões de mundos possíveis ou fragmentos de outros mundos por um sujeitoartista. A essência assim definida (ponto de vista), como casa rústica, degraus esfolados, não se deixa pensar facilmente, mas faz pensar: o sentido de um signo artístico é essa essência irredutível, considerada como singularidade (sentido-essência), liberta de toda determinação exterior, de toda remissão a algo anteriormente conhecido, revelando-se como diferença última absoluta, constituindo os mundos expressos no campo artístico. Proust, sem Deleuze, desenvolve isso da seguinte forma: em primeiro lugar, a questão é que somente pela arte podemos sair de nós mesmos, saber o que enxerga outra pessoa desse universo que não é igual ao nosso, e cujas paisagens permaneceriam tão ignoradas de nós como as por acaso existentes na lua; em segundo lugar, a questão é que graças à arte, em vez de ver um mundo, o nosso, nós o vemos multiplicar-se, e dispomos de tantos mundos quantos forem os artistas originais [...] e que, muitos séculos depois de se haver extinto o núcleo de onde provêm, chame-se este Rembrandt ou Vermeer, ainda nos enviam seus raios especiais ${ }^{252}$.

A essência se encarna nas matérias artísticas (a cor para o pintor, o som para o músico, as palavras para o escritor), que se tornam espirituais, não no sentido de oposição à materialidade, mas no sentido de ultrapassamento dos limites da materialidade: matérias livres, que o verdadeiro artista sabe criar. As frases-tipo de Vinteuil (tomando-se, por agora,

${ }^{252}$ R-TR, p. 683-684. 
tanto um trecho de Proust et les signes ${ }^{253}$ quanto o diálogo entre o herói e Albertine em La prisonnière $^{254}$ ) seriam, no Barbey d'Aurevilly, uma realidade oculta revelada por um traço material; de fato, seriam semelhantes àquela geometria do talhador de pedras nos romances de Thomas Hardy, romances superponíveis uns aos outros, com os talhadores de pedra em Judas, o obscuro, com os blocos de pedra que se tornam estátuas em A bem-amada, com o paralelismo das tumbas e os vagões contíguos em Olhos azuis, com o paralelismo entre o próprio A bem-amada, no qual um homem ama três mulheres, e o próprio Olhos azuis, no qual uma mulher ama três homens. Em Hardy, os blocos de pedra formam, assim, uma espécie de matéria espiritualizada, na qual as próprias palavras vão buscar a sua ordenação; da mesma forma, há em Stendhal certo sentimento de altitude unindo-se à vida espiritual, sendo então a altitude uma matéria aérea: você veria em Stendhal um certo sentimento de altitude unindo-se à vida espiritual, o local elevado em que Julien Sorel está prisioneiro, a torre em cujo cimo está encerrado Fabrice, o campanário no qual o abade Blanès se ocupa de astrologia e de onde Fabrice lança um olhar tão belo. Também o pequeno lanço de muro amarelo no Vista de Delft é uma verdadeira transmutação da matéria, que então se espiritualiza, refratando a essência, evidenciando, antes de sua materialidade, a sua imaterialidade; não por mais nem por menos, a própria morte de Bergotte diante desse quadro, desse meio espiritual povoado de essências, torna-se de alguma maneira menos provável: Uma nova crise o derrubou, fazendo-o rolar do canapé para o chão; acorreram todos os visitantes e guardas. Estava morto. Morto para sempre? Quem o pode afirmar?255. A essência, em sua encarnação artística, aproxima dois objetos diferentes e os relaciona num "meio refrangente", numa "matéria luminosa" (referência a um trecho de Le temps retrouvé no qual Proust discorre sobre o escritor, que deve tomar dois objetos distintos para estabelecer relação entre eles, encerrando-os num estilo harmonioso ${ }^{256}$ ). Essa transmutação da matéria artística, tratamento espiritualizante que revela a qualidade de um mundo original, metamorfose onde a arte se rompe como matéria luminosa, remete ao estilo: "O estilo, para espiritualizar a matéria e torná-la adequada à essência, reproduz a instável oposição, a complicação original, a luta e a troca dos elementos primordiais que constituem a própria

\footnotetext{
${ }^{253}$ PS, p. 60-61 - PS(br), p. 44-45.

${ }^{254}$ R-AP, p. 282-283.

${ }^{255}$ R-AP, p. 141.

${ }^{256}$ R-TR, p. 679.
} 
essência" ${ }^{257}$. Liga-se o estilo, que é uma questão não de técnica, mas de visão ${ }^{258}$, ao ponto de vista pelo qual cada sujeito-artista exprime um mundo, nunca se confundindo mundo expresso e sujeito; o ponto de vista que se define no mundo expresso, ou o mundo expresso que se define na mônada, ou a mônada que se define numa diferença última absoluta, é a condição do estilo, sendo a essência sempre individualizante para uma operação estilística. De fato, como apontado há pouco, o estilo artístico que se revela enquanto diferença qualitativa é a ideia proustiana deixada em Le temps retrouvé; aqui, porém, tal ideia se movimenta na dinâmica paradoxal, deveras interessada, pois não sem evasivas, torções e limbos, do gradiente conceitual deleuze-proustiano: estilo, que envolve ponto de vista, que envolve mundo expresso, que envolve mônada, que envolve essência-diferença (numa palavra, estiloessência: signo artístico como estilo, sentido artístico como essência).

Só a arte, no invólucro original absoluto do eterno, possibilita uma perfeita unidade ou adequação entre signo e sentido, tendo na noção de essência a sua razão. Contudo, é preciso ver que a essência não se encarna apenas na arte; com a revelação que se dá no domínio artístico, aprende-se que ela também se encarna e persiste nos níveis mais baixos, determinando, em cada caso, a relação do signo com o sentido, como um aprendizado inconsciente da própria arte: “A essência é sempre uma essência artista. Mas, uma vez descoberta, ela não se encarna apenas nas matérias espiritualizadas, nos signos imateriais da obra de arte. Ela também se encarna nos outros domínios, que serão, desde então, integrados à obra de arte" ${ }^{259}$. É possível então descer os níveis, identificando a essência em suas sucessivas realizações, os seus efeitos nos outros campos: "Não que tenhamos de retornar à vida, ao amor, à mundanidade. Mas descemos a série do tempo, consignando, a cada linha temporal e

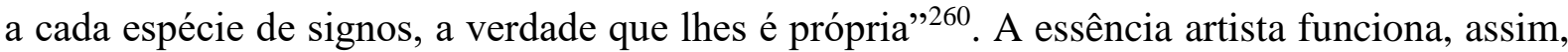
como um terceiro termo, medindo o grau de afastamento ou proximidade entre cada signo e o seu sentido; quando ela penetra os meios mais opacos, como os dos signos amorosos e mundanos, perceptíveis são as marcas de seu esplendor atenuado, tendendo a se confundir com uma lei (da mentira, para os amorosos; do vazio, para os mundanos), porque, na medida em que se descende na ordem dos signos, mais precária ou enfraquecida se apresenta a relação entre signo e sentido, nunca apartada de dados contingentes e determinações

\footnotetext{
${ }^{257}$ PS, p. $62-$ PS(br), p. 45-46.

258 R-TR, p. 683.

${ }^{259}$ PS, p. 64-65-PS(br), p. 48

${ }^{260}$ PS, p. 108 - PS(br), p. 83.
} 
exteriores (explicação material). Machado explica essa ordem descendente, não sem perceber que é possível falar agora em "sentido" ou "essência", desde que a revelação artística (sentido-essência) passou a iluminar e balizar todas as coisas: "A ideia que norteia a argumentação é que o sentido, ou a essência, ao se encarnar nos signos artísticos, sensíveis, amorosos e mundanos, adquire uma forma cada vez mais geral e material, uma generalidade e uma materialidade casa vez maiores, na razão inversa da boa interpretação" ${ }^{261}$. É que os signos materiais (mundanos, amorosos e sensíveis) possuem um sentido demasiadamente preso às contingências externas, indicando um grupo social, uma série de amores, uma localidade, comportando ainda, mesmo no caso dos sensíveis, alguma coisa de material, remetendo a alguma coisa que não é o próprio signo; só os signos imateriais da arte são inteiramente sentido-essência. Em suma, a relação entre signo e sentido é plena somente na arte, quando a essência se encarna sem materialidade nem generalidade, e relativamente sem força nos níveis inferiores dos signos, na medida em que a essência se encarna em dados mais contingentes: fraca nas impressões sensíveis, muito fraca nas experiências amorosas, fraquíssima na vida mundana.

Os signos mundanos, a despeito de sua disseminação vertiginosa nos ambientes de convivência social, são signos vazios, banhados pela vacuidade, frívolos; na mundanidade, não se age nem se pensa, mas emitem-se signos; eles surgem como os substitutos de uma ação ou de um pensamento, ocupando-lhes o lugar, não remetendo a uma significação transcendente ou conteúdo ideal; a forma com que requisitam o pensamento é pobre, tendo uma importância deveras cômica; anulando ação e pensamento, declaram-se, porém, suficientes, pretendendo valer pelo sentido das coisas que substituem: "Nada de engraçado é dito na casa da Sra. Verdurin, e esta não ri; mas Cottard faz sinal de que diz alguma coisa engraçada, a Sra. Verdurin faz sinal de que ri, e seu signo é tão perfeitamente emitido que o Sr. Verdurin, para não parecer inferior, procura, por sua vez, uma mímica apropriada" ${ }^{262}$. Nos salões, fazem acreditar que é preciso ver e escutar, manter-se à espreita, emitidos não raramente em gestos vãos, olhares laterais, risadinhas sem lapidação, algum narizinho empinado ou, por vezes, num excesso de gentilezas interessadas, em sintonia com mil convencionalismos, modismos e esnobismos, deixando transparecer neles alguma coisa

${ }^{261}$ Roberto Machado (2010, p. 199-200).

262 PS, p. 13 - PS(br), p. 6. 
precária, apenas cerimonial: do ponto de vista das ações, decepcionantes; do ponto de vista dos pensamentos, estúpidos. É assim que, nos jantares dos Verdurin, as iguarias, enfeitadas ou adornadas sempre em excesso, têm mais validade pela sua apresentação visual do que pelos seus supostos sabores; à mesa, o acúmulo decorativo, não sem uma ostentação de louças e talheres providencialmente combinada a uma dança de mãos, beiços e dentes, chega a ocultar ou a anuviar os pratos servidos; é que o propósito dessas refeições célebres não é outro senão o de obter algum elogio minguado e causar inveja: as coisas em si mesmas não são apreciadas, só é apreciada a efemeridade que elas causam. Nos Guermantes, ao contrário, deve-se a certa discrição aristocrática, rigorosamente cultivada segundo os códigos que lhes são peculiares, que a comida exista para ser saboreada, pondo o refinamento comensal como uma espécie de quintessência da nobreza; não se pode dizer, contudo, que os signos mundanos se tornam com eles menos vazios, pois estão igualmente assinalados com os artifícios vácuos das suas idiossincrasias mundanas, conforme prescritas por seus legisladores e papas. São signos emitidos, em qualquer circunstância, ao tom de miúdos traquejos e perícias sociais: provocam uma espécie de exaltação nervosa que precisa ser acalmada, uma comoção que sobrecarrega a sensibilidade, certamente impossibilitada de reter ou apreender de imediato o seu funcionamento; exprimem sobre o intérprete o efeito das pessoas que sabem produzi-los, como se elas mesmas detivessem o segredo dos signos que emitem. Despertam a curiosidade, excitam a inteligência, que então se define por uma operação fotográfica de classificação e organização, recorrendo eventualmente à memória voluntária para lhe auxiliar; esta, por sua vez, procede por instantâneos, como retrospectivas do passado a partir do presente, perdendo a essência do tempo, nunca se apoderando do ser-em-si do passado. Sendo vazios, ocos ou fúteis, no extrato mais material, esses signos reaparecem intactos ou idênticos no final de seu desenvolvimento, sem terem despertado, por assim dizer, algum pensamento elevado ou superior, correspondendo, deste modo, a um tempo que se perde. Todavia, não é possível concluir que perder tempo na vida mundana seja inútil, pois ela constitui uma etapa necessária no aprendizado dos signos; o herói, mergulhado em suas migalhas, parece não saber que uma obra está em construção, que uma revelação está em curso: “É por isso que, quando acreditamos que perdemos o nosso tempo, seja por esnobismo, seja por dissipação amorosa, estamos trilhando muitas vezes um aprendizado obscuro, até a revelação final de uma verdade desse tempo que se perde" ${ }^{263}$. Isso significa que é possível extrair verdades até

${ }^{263}$ PS, p. 31 - PS(br), p. 21. 
mesmo do tempo que se perde na mundanidade, desde que o seu intérprete se modifique, não se redescubra de forma idêntica, passe por uma maturação; o bom intérprete, o artista, detecta, assim, como a essência desses signos, as leis vazias que regem a vida social, considerando que mesmo os bobos ou tolos emitem os signos dessas leis: As criaturas mais estúpidas manifestam, por seus gestos, frases e sentimentos involuntariamente expressos, leis de que não se dão conta, mas que o artista nelas surpreende ${ }^{264}$. Conhecer determinado grupo social é saber interpretar os gestos, as frases e os sentimentos que involuntariamente assinalam a existência de leis gerais; a essência aqui se encarna enquanto generalidade de grupo, leis gerais de grupo, o último grau da essência, as leis do vazio.

Os signos amorosos, no âmbito das perfídias, dos segredos e das ilusões, são signos enganadores ou mentirosos, escondendo justamente o que o amante deseja conhecer: a origem das ações e dos pensamentos que lhes dão sentido. O intérprete do amor é, necessariamente, um intérprete de mentiras, que são os hieróglifos do amor; há leis de contato, atração e repulsão que constituem em cada experiência amorosa um verdadeiro tratado de falsidade; no ponto, as mentiras de uma mulher medíocre, por exemplo, conseguem enriquecer até mesmo o universo de homens intelectuais e sensíveis, despertando o ciúme e interessando à inteligência, bem mais do que faria uma mulher não medíocre: Atrás de cada uma de suas palavras eles sentem uma mentira; atrás de cada casa aonde ela diz ter ido, uma outra casa; atrás de cada ação, cada criatura, uma outra ação, uma outra criatura ${ }^{265}$. Esses signos provocam angústia ou sofrimento, trazendo a traição e a separação como hipóteses perpétuas, seja quando o amante transita em suspeitas genuínas, seja quando o amante transita em suspeitas infundadas, como que antecipando a falência de todos os afetos, correspondendo, deste modo, a um tempo perdido no estado mais puro. Também é a inteligência a faculdade que os desenvolve, recorrendo igualmente à memória voluntária, que, sendo solicitada indiretamente, só pode oferecer uma contribuição voluntária, chegando tarde demais com relação aos signos a se decifrar, condenando-se muitas vezes a um patético fracasso; num exemplo, a memória do herói, não tendo retido de Albertine alguma afirmação primitiva, é vista como um auxiliar pífio para a decifração dos signos: Posteriormente, gostaria de me lembrar; era em vão; minha memória não fora prevenida a tempo; havia julgado inútil guardar uma cópia ${ }^{266}$. A verdade desse tempo perdido é múltipla, aproximativa, equívoca:

\footnotetext{
264 R-TR, p. 687.

265 R-AF, p. 465.

${ }^{266}$ R-AP, p. 116.
} 
num primeiro momento, a interpretação se liga ao objeto, porque os signos fazem acreditar que é preciso confessar o sentimento ao ser amado, render uma homenagem; depois, incitam a subjetividade, com a necessidade de não confessar, de não enriquecer o objeto com significações que o ultrapassam, para preservar eventualmente amores futuros, que então se antecipam por um mecanismo de associação de ideias, onde tudo é permitido; contudo, na medida em que a capacidade de amar se deteriora, pressente-se a existência de uma verdade que relativamente ultrapassa tanto o objeto quanto o sujeito; na dinâmica das experiências, essa verdade aparece no momento em que o "eu" que amava já não existe mais. O bom intérprete, o artista, detecta, assim, como a essência desses signos, duas leis gerais que se vinculam, envolvendo o ciúme, aspecto subjetivo da mentira, e a homossexualidade, aspecto objetivo da mentira. A lei subjetiva diz respeito às sensações daquele que ama: o ciúme é mais profundo do que o amor, dada a impossibilidade de se gozar no amor uma preferência absoluta ou exclusiva; a contradição do amor consiste no fato de que os meios utilizados para se preservar do ciúme são os mesmos que o desenvolvem; o ciumento, segundo Proust, não hesita em formular suspeitas atrozes acerca de fatos inocentes, com a condição, diante da primeira prova que lhe tragam, de se recusar à evidência ${ }^{267}$. A lei objetiva diz respeito à verdade do amor, o segredo de Sodoma e Gomorra: todas as mentiras se ordenam em torno da homossexualidade, sendo os amores homossexuais mais profundos do que os amores intersexuais; os níveis da intersexualidade e da homossexualidade exigem, porém, a compreensão de um terceiro nível, o da transexualidade, a coexistência de dois sexos num mesmo sexo, o hermafrodita original. A essência aqui se encarna não como generalidade de grupo, mas como generalidade de série, pois o amor é serial, profundamente vivido segundo as séries nas quais ele se organiza, séries implicadas umas nas outras, entrelaçando-se, envolvendo índices de variações e leis de progressão. Não há, portanto, apenas uma série de amores sucessivos (a mãe, Gilberte, a duquesa de Guermantes, Albertine), mas também uma série particular, formada em cada experiência amorosa (Albertine é Albertines); não há apenas uma série de amores sucessivos e uma série particular, mas também uma série transubjetiva, encadeando séries com séries (Albertines com Odettes): "No limite, a experiência amorosa é a da humanidade inteira, que atravessa a corrente de uma hereditariedade transcendente" 268 . O trabalho da inteligência consiste em transmutar os sofrimentos em alegria; os fatos são sempre

\footnotetext{
${ }^{267}$ R-AP, p. 66.

${ }^{268}$ PS, p. 89 - PS(br), p. 68
} 
tristes ou penosos, mas a ideia que deles se extrai é finalmente alegre, convergindo para a obra de arte: "Nós nos apercebemos de que nossos sofrimentos não dependiam do objeto. Eram 'rodeios` ou 'farsas` que fazíamos para nós mesmos, ou melhor, armadilhas e coquetismos da Ideia, alegrias da Essência"269. Proust assim escreve, sobre a obra de arte e o amor: Mas sob outro ponto de vista, a obra é sinal de felicidade, pois nos ensina que em todo amor o geral jaz ao lado do particular e, ao passar do segundo para o primeiro devido a uma ginástica fortalecedora contra o desgosto, torna desprezível o que o provocou a fim de aprofundar a sua essência ${ }^{270}$.

Os signos sensíveis não são vazios nem mentirosos, mas verídicos, proporcionando súbitas e extraordinárias alegrias, efeitos imediatos que já os fazem distintos dos precedentes. São materiais na origem (madeleine, campanários, pedras do calçamento, guardanapo) e na explicação (Combray para a madeleine, as jovens para os campanários, Veneza para as pedras do calçamento, Balbec para o guardanapo), em estrita dependência, portanto, de uma ordem material de emissão e interpretação. De início, fazem acreditar que é preciso observar e descrever a coisa sensível, equívoco objetivista que leva a decepções; em seguida, incitam associações subjetivas, como a evocação de outras impressões, o que também leva a desapontamentos; enfim, a verdade deles aparece pelo poder que têm de ressuscitar ou suscitar o "eu" que corresponde ao seu sentido, o "eu" que, na passagem do tempo, parecia morto. Formam um começo da arte, implicando uma imagem fugaz da eternidade, no âmago do próprio tempo perdido, correspondendo, deste modo, a um tempo que se redescobre: "Nunca nosso aprendizado encontraria seu resultado na arte se ele não passasse por esses signos que nos dão uma antecipação do tempo redescoberto e nos preparam para a plenitude das Ideias estéticas" ${ }^{271}$. São desenvolvidos ora pela memória involuntária (como no caso da madeleine, das pedras do calçamento ou do guardanapo), ora pela imaginação (como no caso dos campanários de Martinville), tendo-se que Proust distingue claramente reminiscências e verdades escritas com o auxílio de figuras ${ }^{272}$; é que a memória involuntária, a despeito de ser a principal faculdade solicitada por esses signos, não possui o segredo de todos eles: alguns apelam ao desejo e à imaginação. A diferença entre memória voluntária, aquela que auxilia a inteligência no desenvolvimento dos signos mundanos e amorosos, e memória involuntária,

\footnotetext{
${ }^{269}$ PS, p. 91 - PS(br), p. 70.

${ }^{270}$ R-TR, p. 690.

${ }^{271}$ PS, p. 69 - PS(br), p. 51.

272 R-TR, p. 671.
} 
esta que desenvolve a maioria dos signos sensíveis, reside no seguinte fato: a primeira, a rigor, não se apodera do passado tal como ele se conserva em si; suas informações sobre o passado, diz Proust, nada conservam dele ${ }^{273}$; ela recompõe o passado a partir do presente, como uma regressão do presente ao passado, não demandando esforço maior do que folhear um livro de figuras ${ }^{274}$; nela, o passado se constitui interposto entre dois presentes, o presente que ele mesmo já foi e o atual presente em relação ao qual ele é agora passado (o lembrado já foi visto ou ouvido); a segunda, ao contrário, além de não depender de um esforço consciente, apodera-se do ser-em-si do passado, recuperando o passado tal como ele se conserva em si, sem se constituir passado depois de ter sido presente; nela, não se retorna do presente ao passado, não se recompõe o passado pelo presente, situa-se imediatamente o próprio passado, que não representa alguma coisa que foi, mas alguma coisa que é e coexiste consigo como presente (o lembrado nunca foi visto ou ouvido). Aqui, Deleuze com Proust é Deleuze com Bergson, destacando semelhanças entre as concepções bergsoniana e proustiana no nível do ser-em-si do passado, ainda que Bergson nunca tenha considerado a maneira pela qual o passado pode ser recuperado: "Este ser-em-si do passado, Bergson o chamava de virtual"275. Refere-se, assim, mais propriamente, a um trecho que aparece no final da Recherche, momento em que as impressões ou qualidades sensíveis se multiplicam num curto espaço de tempo, estando o herói decidido a não adiar a busca pelas causas profundas da felicidade que esses signos provocam: Mas desde que um ruído, um cheiro, já ouvido ou aspirado antes, o sejam de novo, ao mesmo tempo no presente e no passado, reais sem serem atuais, ideais sem serem abstratos, logo a essência permanente e em geral oculta das coisas se libera ${ }^{276}$. Esse virtual (reais sem serem atuais, ideais sem serem abstratos) é a essência que se encarna na memória involuntária, segundo a complicação deleuze-proust-bergsoniana; Combray, Veneza ou Balbec não aparece como foi vivida, mas num passado puro, inacessível à memória voluntária atual e à percepção consciente antiga: essência localizada no tempo, uma fração de tempo em estado puro. A princípio, a memória involuntária parece se basear na semelhança entre uma sensação presente e uma sensação passada; de modo mais profundo, essa semelhança remete a uma qualidade idêntica às duas sensações; todavia, a semelhança e a identidade são apenas as condições primevas, de gênese; o bom intérprete, o artista, detecta,

\footnotetext{
${ }^{273}$ R-CS, p. 50.

274 R-TR, p. 667.

275 PS, p. 73 - PS(br), p. 55.

276 R-TR, p. 666.
} 
assim, como a essência desses signos, uma diferença interiorizada na percepção atual, tornada imanente, que então se depõe como o próprio ser-em-si do passado, a essência como realidade virtual: se na memória voluntária Combray se mantém exterior à madeleine, aspecto perceptível quando a cidade se apresenta para uma simples digressão, na memória involuntária, que se perfaz na experiência sensível, Combray é aprisionada e envolvida no sabor da madeleine como um objeto diferente, absolutamente novo, jamais vivido. Eis Deleuze com Proust o que diz: "Combray aparece como não podia ter sido vivida: não em realidade, mas em sua verdade; não em suas relações exteriores e contingentes, mas em sua diferença interiorizada, em sua essência" 277 . A essência aqui se encarna num grau superior ao grau da mundanidade e do amor, mas inferior ao da arte, apresentando ainda uma mínima generalidade: por um lado, ela não aparece como a qualidade última de um ponto de vista singular, como é a essência artista; surge como uma essência local, remetendo a Combray, Veneza ou Balbec, e como uma essência particular, revelando a verdade diferencial de um lugar, de um momento; por outro lado, ela se mostra como uma essência geral, trazendo a verdade numa sensação comum a dois lugares, dois momentos: Nessas ressurreições, o local distante engendrado em torno da sensação comum sempre se agarrava, por um momento, como um lutador, ao local de hoje $e^{278}$.

Os signos artísticos, superiores aos outros, são signos essenciais: a matéria se espiritualiza e refrata a essência (sentido-essência), como diferença última absoluta, sem materialidade nem generalidade, constituindo uma perfeita unidade ou adequação entre signo e sentido. O resultado da busca é, assim, a revelação da essência dos signos artísticos e, por conseguinte, o aprendizado de sua encarnação nos níveis mais baixos, como já se viu. A essencialidade artística se insere exatamente no seu poder transformador em relação a todos os signos, principalmente sobre os sensíveis, dando-lhes o colorido de um sentido estético: "No final da Recherche, o intérprete compreende o que lhe escapara no caso da madeleine ou mesmo dos campanários: o sentido material não é nada sem uma essência ideal que ele encarna. [...] O que permite agora ao intérprete ir mais além é que, nesse meio-tempo, o problema da Arte foi colocado e recebeu uma solução" 279 . É mesmo verdade que, para o herói proustiano, o domínio artístico de algum modo sintetiza as impressões ou qualidades sensíveis: a vista das árvores que eu julgara reconhecer num passeio de carro pelos

\footnotetext{
277 PS, p. $76-$ PS(br), p. 57.

278 R-TR, p. 668.

${ }^{279}$ PS, p. 21 - PS(br), p. 12-13.
} 
arredores de Balbec, a vista dos campanários de Martinville, o sabor da madeleine mergulhada no chá, e tantas outras sensações de que já falei e que as últimas peças de Vinteuil me pareciam sintetizar ${ }^{280}$. Adiante, em torno ainda do projeto de se tornar escritor, ele percebe que a obra de arte é o único meio de converter tais experiências sensíveis num equivalente espiritual: era preciso tentar interpretar as sensações como signos de outras tantas leis e ideias, procurando pensar, isto é, fazer sair da penumbra aquilo que sentira, convertê-lo num equivalente espiritual. Ora, este meio, que me parecia o único, que outra coisa era senão compor uma obra de arte $?^{281}$. Mas isso não significa de forma alguma que os signos da memória involuntária e da imaginação sejam desimportantes, tampouco que essas faculdades não sejam um meio necessário na busca da verdade; o que o bom intérprete, o artista, aponta é apenas o seu papel secundário, menos profundo: "Proust fala muitas vezes da necessidade que pesa sobre ele: sempre alguma coisa lhe lembra ou the faz imaginar outra coisa. Mas, qualquer que seja a importância desse processo de analogia na arte, não é sua fórmula mais profunda" 282 . A arte, segundo a complicação deleuze-proustiana, não se vale da inteligência, da memória (voluntária, involuntária) nem da imaginação, mas do pensamento puro como faculdade das essências, que é a forma cabal do involuntário, diversificada pelas faculdades que desenvolvem os outros signos: "Sob os signos da arte, aprendemos o que é o pensamento puro como faculdade das essências e como a inteligência, a memória ou a imaginação o diversificam com relação às outras espécies de signos" ${ }^{283}$. É possível dizer, não sem salientar o caráter especial desse problema, que o pensamento puro assume como objeto aquilo que deve ser pensado e, ao mesmo tempo, é impensável; ele não pensa senão numa relação essencial com aquilo que ele não pensa; como diz Lapoujade, "Deleuze sempre concebeu o princípio de razão suficiente como um grito filosófico, mas porque envolvido nele também está o grito da desrazão" ${ }^{284}$; neste ponto, como parênteses, um trecho de Différence et répétition ajuda a previamente dissipar a aparente contradição entre pensável e impensável: "Que o pensamento, por exemplo, encontre em si algo que ele não pode pensar, que é, ao mesmo tempo, o impensável e aquilo que deve ser pensado - isto só é incompreensível do ponto de vista de um senso comum ou de um exercício calcado sobre o empírico" ${ }^{285}$. O

\footnotetext{
280 R-TR, p. 662.

281 R-TR, p. 671.

282 PS, p. 53 - PS(br), p. 38.

283 PS, p. 120 - PS(br), p. 92.

${ }^{284}$ David Lapoujade (2015, p. 35).

${ }^{285}$ DR, p. 311.
} 
sujeito-artista é aquele que, involuntariamente, não comprimido pelo senso comum e pelo bom senso, libera em sua criação o pensamento puro como faculdade das essências "alógicas ou supralógicas", entre o pensável e o impensável; esta faculdade essencial, encontrando a sua diversificação em outras faculdades, expressa mundos possíveis ou fragmentos de outros mundos, isto é, desenvolve os signos imateriais do não-percebido ou do impensável naquilo que o sujeito-artista materialmente percebe ou pensa (pequeno lanço de muro amarelo em Vermeer, pequena frase musical de Vinteuil); os mundos expressos, que formando todo um campo de virtualidades e potencialidades desenlaçam a alegria pura da arte, pertencem à essência artista, diferença última absoluta que, como pátria desconhecida, liberta de toda determinação exterior, de toda remissão a algo anteriormente conhecido, individualiza o sujeito em que se incorpora: “Assim, na arte, a própria essência individualiza o sujeito em que ela se incorpora e determina absolutamente os objetos que a exprimem"286.

286 PS, p. 109 - PS(br), p. 83. 


\section{QUATRO}

Na segunda parte, “A máquina literária”, publicada em 1970 e concluída em 1976, a incidência é a obra de Proust como um mundo de signos que se opõe ao logos de cinco pontos de vista: "pela figura das partes que os signos recortam no mundo, pela natureza da lei que revelam, pelo uso das faculdades que requerem, pelo tipo de unidade que deles decorre e pela estrutura da linguagem que os traduz e interpreta"287. $\mathrm{Na}$ aba, mas inabalado, o logos é a forma clássica de organização do pensamento; suas viaturas cinematográficas são adestradas nas alturas fotográficas de uma unidade ou totalidade lógica e orgânica: harmoniosa e satisfeitíssima congregação partes-todo. Com a antena de Atenas, ele é encontrável na verdade racional e analítica dos filósofos de tipo clássico, naquele pensamento que se confunde com uma "conversa entre amigos", celebridades celebrando sentenças célebres, depois de se iniciarem, talvez, pela incrível tradição do beija-mão, mas também nas premeditadas normatividades e tecnicalidades dos cientistas e nas obras premeditadas dos literatos, envolvendo em todos os casos um estilo-logos, uma estrutura de linguagem sem impureza, um simbolismo convencional nas palavras empregadas. No logos, todas as faculdades se exercem voluntariamente, e colaboram, sob o escudo da inteligência, para costurar um vínculo direto e simpático entre partes e todo; assim, a inteligência vem sempre antes, já contaminada pelo conhecimento da lei e, consequentemente, pela presença do todo, inteligência administrada numa unidade ou totalidade original, já existente, ou estrategicamente predestinada a uma unidade ou totalidade de destinação, ainda por vir. É no seguinte sentido, pois, que a Recherche é um antilogos para Deleuze com Proust: já não existe logos porque nela a aventura própria do involuntário leva o pensamento ao abismo do impensável (que, todavia, só se pode pensar); as faculdades se situam numa linha vulcânica que as queima uma na outra; o logos se quebra em hieróglifos, ilegível, como punhados de areia fina que se deixam escorrer entre os dedos; já não existe logos porque nela há uma lei desconhecida, apenas vazia e formal, regendo fragmentos não totalizáveis, separando-os, compartimentando-os, sem que sejam necessários aforismos; essa lei primariamente incognoscível, que é a lei da consciência moderna, opõe-se ao logos, por exemplo, no nível da

${ }^{287}$ PS, p. 131 - PS(br), p. 102. 
transexualidade, como se verá; já não existe logos porque nela só pode ocorrer uma unidade posterior (efeito do múltiplo), como uma parte composta à parte, visto que os fragmentos não se deixam totalizar, valendo por si mesmos; enfim, já não existe logos porque nela o estilo é um não-estilo (ou um estilo antilogos), multiplicando os pontos de vista sobre a frase, no interior da frase, funcionando como uma espécie de equipamento de encaroçar, enroscar ou entulhar as coisas. Evidentemente, toda essa questão do antilogos, que aqui apenas se depõe num singelo alvoroço de raspas pálidas e repetitivas, implicará, depois, na obra de DeleuzeGuattari, exigências conceituais tornadas cada vez mais explícitas, como a de pensar, em L'Anti-Oedipe, no "estatuto das multiplicidades" ou, em Mille plateaux, no caráter rizomático das multiplicidades: “As multiplicidades são rizomáticas e denunciam as pseudomultiplicidades arborescentes. Inexistência, pois, de unidade que sirva de pivô no objeto ou que se divida no sujeito. Inexistência de unidade ainda que fosse para abortar no objeto e para 'voltar' no sujeito" 288 . Assim, tomado em sentido amplo, o problema do antilogos deleuze-proustiano jamais se reduz à Recherche, mas à questão geral do pensamento em si, operada entre compostos conceituais.

Há uma presença muito viva da loucura em Proust, distribuída com grande habilidade, contornando a viciosa vigilância do logos, a começar pela loucura de Charlus e Albertine (questão que se apresenta no final de Proust et les signes, no capítulo supostamente conclusivo "Presença e função da loucura. A aranha"). É possível assimilar a loucura proustiana no sentido que Deleuze expõe em 1975, numa conversação com Barthes, Genette, Ricardou e Richard: "Quanto a saber o que é essa loucura e em que ela consiste, acredito que se poderia falar de esquizofrenia" 289 . A loucura de Charlus é uma perspectiva imediata, colocada desde as suas primeiras aparições na Recherche: ele é um louco, uma nebulosa individual que contém e oculta coisas desconhecidas; seus olhos combinam domínio, bisbilhotice e indiferença; sua voz, misturando discurso e expressão, combina virilidade e maneirismo efeminado. É verdade que dessa nebulosa individual jorram discursos com palavras e frases voluntariamente organizadas, começando todos eles por uma operação de denegação; porém, alguma coisa na nebulosa sempre descarrilha, agitada por signos involuntários, fazendo desaparecer o logos, em proveito do pathos, aquele ambiente esquizoide da sexualidade, com partes fechadas ou compartimentadas que só se resolvem

288 MP1, p. 16.

${ }^{289}$ DRF, "Table ronde sur Proust", p. 53. 
numa comunicação aberrante. A loucura de Albertine, por sua vez, não é uma perspectiva imediata, mas uma dúvida, uma possibilidade colocada no final: talvez ela estivesse louca, talvez ela sempre tenha sido louca. Múltiplas séries se desprendem da nebulosa das moças em flor, marcadas por erupções sadomasoquistas, balizadas por sequestro, voyeurismo e profanação, como séries cruéis; no termo das séries, não existe apenas uma Albertine, mas muitas Albertines, como partes isoladas e espalhadas, que igualmente não podem se comunicar senão por uma comunicação aberrante. Na verdade, efetivamente louco é o narrador, um narrador bizarro, manejando, por exemplo, essa loucura de Charlus e Albertine, como a figura do esquizo em L'Anti-Oedipe, com as suas linhas de fuga, seu corpo sem órgãos e suas imprevistas reordenações dos códigos sociais. Sem olhos, sem nariz, sem boca, esse narrador nada vê, nada percebe, de nada se lembra, respondendo apenas à violência imediata dos signos. Isso não significa que ele de fato não tenha olhos, nariz ou boca, tampouco que ele de fato não tenha conhecimentos históricos, geográficos ou psicológicos, alguma bagagem intelectual; a questão é que, nos encontros intensivos, na situação de vibração-mosca nervosa que se propaga até o seu corpo, na pressão dos signos que lhe exigem um trabalho do pensamento, de nada valem os órgãos e o organismo, impedido que ele está de todo o uso voluntário e organizado das faculdades: "Na verdade, o narrador é um enorme Corpo sem órgãos" ${ }^{290}$. Ele é um "sujeito larvar", realmente vulnerável às potencialidades dos encontros intensivos (afinal, quando se tem órgãos, quando o organismo já está formado, quando o pensamento adquire também uma forma pessoal, é tarde demais para o verdadeiro pensamento); ele é uma aranha concentrada somente em sua teia, que é a Recherche que se faz; ele é um narrador-aranha: "Esse corpo-aranha do narrador [...] vai estender um fio até Charlus, o paranoico, um outro até Albertine, a erotômana, para fazê-los marionetes de seu próprio delírio, potências intensivas de seu corpo sem órgãos, perfis de sua loucura" ${ }^{291}$. Podese ouvir aqui, talvez mesmo por ouvidos de feto, o barulho dos instrumentos cirúrgicos nessa língua-pensamento, desde que, apesar dela ou por causa dela, longe ainda de uma indolente partie de plaisir, as alternativas se tornaram ilimitadas, fazendo com que cada rota se bifurque e torne a se bifurcar num panorama bastante complexo: no Proust et les signes, corpo sem órgãos, conceito que, retirado de Artaud, atravessa desigualmente toda a obra posterior de Deleuze e Deleuze-Guattari, retorcendo-se infinitésimas vezes nas vibro-variabilidades que

\footnotetext{
290 PS, p. 218 - PS(br), p. 172.

291 PS, p. 218-219-PS(br), p. 173.
} 
lhe são constituintes, corresponde à aventura do involuntário, um pensamento antilogos que se organiza em partes primariamente não comunicantes, ganhando unidade ou comunicabilidade apenas em sua dimensão transversal. A noção guattariana de transversalidade, conforme apresentada, por exemplo, no livro Psychanalyse et transversalité, torna-se por agora um elemento inspirador; para Guattari, trata-se de uma dimensão que pretende superar dois impasses, o de uma verticalidade pura e o de uma simples horizontalidade: "a transversalidade tende a se realizar quando ocorre uma comunicação máxima entre os diferentes níveis e, sobretudo, nos diferentes sentidos"292. Em “Table ronde sur Proust", Deleuze completa: "Acho que se pode chamar transversal uma dimensão que não é horizontal nem vertical, supondo, naturalmente, tratar-se de um plano"293. É que a transversal, como se formula melhor em L'Anti-Oedipe, no bojo do problema do "estatuto das multiplicidades", é um todo produzido como uma parte ao lado das partes, "que ele não unifica nem totaliza, mas às quais se aplica instaurando comunicações aberrantes entre vasos não comunicantes, unidades transversais entre elementos que mantêm toda a sua diferença nas suas dimensões próprias" 294 .

Em primeiro lugar, o mundo dos signos se opõe ao logos do ponto de vista das partes que os signos recortam no mundo, partes que devem ser compreendidas como objetos parciais, segundo duas figuras de funcionamento: continente-conteúdo e partes-todo. A primeira é uma figura de encaixe, envolvimento ou implicação, denominada pela imagem de “caixas entreabertas", valendo pela posição de um conteúdo sem medida comum: das coisas, dos seres e dos nomes se extrai algo de natureza totalmente diferente, um conteúdo desmedido; a atividade do narrador consiste em explicar o conteúdo do incomensurável ao continente. A segunda é uma figura de complicação, denominada pela imagem de "vasos fechados", valendo pela oposição de uma vizinhança sem comunicação: trata-se agora da coexistência de instâncias compartimentadas e não comunicantes, como metades separadas, lados opostos ou partes contrárias que se põem em giro, arrastando ou misturando tudo o que poderia ser fixo; a atividade do narrador, pelo menos em sua feição aparente, dado que forças distintas competem para determinar, pela coação, a sua pseudovontade, consiste em eleger ou

\footnotetext{
292 Felix Guattari (2004, p. 111).

${ }^{293}$ DRF, "Table ronde sur Proust", p. 43.

${ }^{294}$ AE, p. 63.
} 
escolher um vaso fechado, isto é, determinada jovem num grupo de jovens, determinada palavra dessa jovem, determinado sofrimento que essa jovem faz sentir etc. Os signos emanam de coisas, seres ou nomes que são como caixas entreabertas ou vasos fechados, e essas duas figuras frequentemente se misturam; Albertine, por exemplo, encaixa, envolve ou implica a praia e as ondas (explicação do narrador), mas também complica em si muitas personagens, das quais é possível privilegiar uma, de acordo com as circunstâncias (eleição ou escolha do narrador). Há sempre a preferência por uma dessas duas figuras, mas cada categoria da Recherche, concebida originalmente numa figura, encontra o seu duplo na outra figura, como um mesmo e inteiramente outro, a um só tempo: no caso da linguagem, os nomes próprios são caixas das quais se extrai o conteúdo (o sobrenome Guermantes com a auréola do prestígio) e, uma vez esvaziados pela frustração (Guermantes é só um sobrenome), ordenam-se uns em função dos outros (Guermantes, Verdurin e outros nomes próprios, como história universal), enquanto os nomes comuns introduzem no discurso pedaços discordantes de mentira e verdade, eleitos ou escolhidos pelo narrador; no caso das faculdades, a memória involuntária abre as caixas, desdobra o conteúdo oculto (Combray para a madeleine), enquanto o desejo faz girar os vasos fechados, exigindo eleição ou escolha daquele que melhor convém; no caso do amor, enfim, as recordações se ocupam em extrair, por exemplo, o conteúdo de Albertine, trabalhando por regiões de lembrança ${ }^{295}$, enquanto o desejo se ocupa em multiplicar Albertines não comunicantes (Albertine é Albertines).

Quanto a figura das caixas entreabertas, cabe perguntar qual é o continente e em que consiste o conteúdo. Eis Deleuze com Proust o que diz, tomando como exemplo a madeleine: “O verdadeiro continente não é a taça, mas a qualidade sensível, o sabor. E o conteúdo não é uma cadeia associada a este sabor, a cadeia das coisas e das pessoas conhecidas de Combray, mas Combray como essência" ${ }^{296}$. Há aqui uma recuperação de ideias já construídas na primeira parte de Proust et les signes, estendendo-se agora em dois aspectos complementares, que envolvem tanto o problema da relação entre continente e conteúdo quanto a forma de explicação do narrador: em primeiro lugar, o continente, que não é o objeto que emite o signo, mas a própria impressão ou qualidade sensível, é o que permite extrair o conteúdo, que em última instância não consiste em aproximações objetivas nem associações subjetivas, mas na essência, pensada como ponto de vista, sem medida comum, liberta de toda determinação

\footnotetext{
295 R-AP, p. 290.

296 PS, p. 144 - PS(br), p. 112.
} 
exterior, de toda remissão a algo anteriormente conhecido; em segundo lugar, o conteúdo, que consiste na essência, implica uma reindividuação do "eu", a revivência de uma existência pura jamais vivida (essência individualizante, superior ao indivíduo), o que significa dizer que a explicação do narrador, no caso da madeleine, é uma espécie de ressurreição do "eu". O amor e o ciúme, em outro nível, também são comandados por essa atividade de explicação, não raramente se desdobrando no seguinte duplo movimento: paisagens ou lugares se enrolam na amada, que, por sua vez, desenrola as paisagens ou os lugares nela encerrados. Nessa trama que, não sem complexas distorções, combina o mundo expresso pelo ser amado com a explicação de seu conteúdo, o próprio narrador, apaixonado e ciumento, precisa enclausurar a amada para melhor explicá-la, esvaziando-a de todos os mundos desconhecidos, como uma devolução ou restituição de seu próprio "eu": Encerrando Albertine, eu ao mesmo tempo devolvera ao universo todas aquelas asas reluzentes que sussurravam nas avenidas, nos bailes, nos teatros, e que se tornavam tentadoras para mim porque ela já não podia sucumbir à sua tentação $o^{297}$. É certo que dos princípios básicos ou das linhas gerais dessa operação poucos haveriam de discordar; Lavagetto, por exemplo, discorre que "tudo o que na Recherche é conhecido através do olho aparentemente imunizado do observador se transforma em signo do destino: ver significa se condenar a reviver, a experimentar na primeira pessoa"298; evidentemente, esse reviver se localiza em pelo menos dois sentidos: reviver a experiência e se reviver. Aqui, porém, a complicação deleuze-proustiana reclama um ajuste significativo: não se trata exatamente de devolver ou restituir o "eu", mas de esvaziar cada um dos "eus" que amou Albertine, "segundo uma lei de morte que se entrelaça com a das ressurreições, como o Tempo perdido se entrelaça com o Tempo redescoberto"299; é que, na verdade, os "eus" amantes tanto se obstinam em revivências, em reanimar as suas vidas, quanto em suicídios, em preparar os seus desaparecimentos; nas experiências amorosas, pois, o investimento do conteúdo se mescla com vida e morte.

As caixas só são "entreabertas" no sentido de uma operação continente-conteúdo. O conteúdo (essência) se atém ao continente (qualidade sensível) pela força da incomensurabilidade que traz consigo; manifesta-se, deste modo, a inadequação do conteúdo, um conteúdo verdadeiramente incomensurável, seja "conteúdo perdido", aquele que se redescobre no esplendor de uma essência que ressuscita um “eu”, seja "conteúdo esvaziado",

\footnotetext{
${ }^{297}$ R-AP, p. 130.

298 Mario Lavagetto (1996, p. 79).

${ }^{299}$ PS, p. 146 - PS(br), p. 114.
} 
aquele que provoca a morte do "eu", seja ainda "conteúdo separado", aquele que lança tudo numa inevitável decepção. Mesmo as cadeias subjetivas, cuja qualidade não é outra senão a de evocar os estados transitórios do sujeito da percepção, frequentemente se rompem em proveito de enfoques transcendentes, ora exprimindo verdades da ausência ou do tempo perdido, ora exprimindo verdades da presença ou do tempo redescoberto. Com efeito, ocorre um imenso painel de verdades discordantes, o que não deixa de ser um replicado desenho de pensamento, à revelia de qualquer ideia convencional de unidade: "não só se assiste a essa espécie de explosão dos continentes pelos conteúdos, mas a essa explosão dos próprios conteúdos que, desdobrados, explicados, não formam uma figura única, mas verdades heterogêneas em fragmentos que lutam muito mais entre si do que se conciliam" ${ }^{300}$. Tudo indica fragmentação e não conciliação, desde essas caixas entreabertas que os signos recortam no mundo; mesmo na arte, com o mais alto estado da essência, pedaços disparatados combatem, como é possível ver, por exemplo, em La prisonnière, na execução do septeto de Vinteuil, com a luta de dois motivos musicais: E logo os dois motivos lutaram juntos num corpo-a-corpo onde às vezes um desaparecia completamente, em que a seguir só se percebia um trecho do outro ${ }^{301}$. O conteúdo incomensurável se extrai, por assim dizer, pela orientação de uma ideia-foto demasiadamente banhada por uma ideia-cinema; não mais, portanto, um pensamento revestido apenas por uma ideia-foto, mas por uma ideia foto-cinema; nesse sentido, semelhante é o septeto a um desenho de pensamento jazzístico mais extremado, quando as improvisações lutam em agonia com os temas melódicos, prestes a abandoná-los, ameaçando-os. Contudo, nos termos da engenharia deleuze-proustiana, é preciso destacar não uma possível relação entre explicação e experiência, mas a própria luta não pacificada e irregular que existe nos conteúdos; desdobrados ou explicados, eles não compõem uma totalidade, compõem fragmentos, assim como não compõem uma eternidade, compõem fragmentos de tempo, num encadeamento de partes desconexas ou inconciliáveis: "Mas a força com que elas são projetadas no mundo, inseridas violentamente umas nas outras [...] faz com que elas todas sejam reconhecidas como partes, sem no entanto compor um todo, mesmo que seja oculto, sem emanar totalidades, mesmo que sejam perdidas"302.

Quanto a figura dos vasos fechados, cabe perguntar qual é a oposição da vizinhança sem comunicação e em que consiste a relação partes-todo. Eis Deleuze com Proust o que diz,

\footnotetext{
${ }^{300}$ PS, p. $147-148$ - PS(br), p. 115.

${ }^{301}$ R-AP, p. 196.

${ }^{302}$ PS, p. 148-149 - PS(br), p. 116.
} 
tomando como exemplo o rosto de Albertine: "quando acreditamos juntá-lo para um beijo, salta de um plano a outro durante o percurso de nossos lábios à sua face; 'dez Albertines`em vasos fechados, até o momento final quando tudo se desfaz na proximidade exagerada" ${ }^{303}$. Os vasos fechados são instâncias compartimentadas e não comunicantes, isto é, objetos parciais, como as distintas feições de um rosto progressivamente visitado, pedaços não dialógicos de diferentes quebra-cabeças, assimétricos, sem arestas arredondadas, não pacificados; é assim que, noutro exemplo, os dois lados da Recherche, o de Méséglise-la-Vineuse e o de Guermantes, tanto opostos quanto irreconhecíveis um ao outro, permanecem justapostos nos vasos cerrados e não comunicantes entre eles ${ }^{304}$. Há nisso uma construção esquizoide por excelência: não se considera nas partes uma totalidade original, supostamente já existente, nem uma totalidade de destinação, supostamente ainda por vir; os vasos fechados têm entre si relações de diferença enquanto tal, sem referência a uma totalidade. É verdade que há um sistema de passagem entre essas partes herméticas, ainda que nunca envolvendo uma comunicação direta, mas uma comunicação aberrante, como ocorre na profanação sádica da Srta. Vinteuil, cuspindo sobre o retrato do pai recentemente morto; trata-se de uma dimensão transversal, que afirma os fragmentos disparatados, irredutíveis ao todo, assegurando a imanência do um ao múltiplo e do múltiplo ao um, implicando, enfim, o problema dissonante da relação partes-todo que aí se investe. Eis Deleuze e Guattari o que dizem em L'AntiOedipe, como extensão indispensável desse pensamento: "Só acreditamos em totalidades ao lado. E se encontramos uma totalidade ao lado das partes, ela é um todo dessas partes, mas que não as totaliza, uma unidade de todas essas partes, mas que não as unifica, e que se junta a elas como uma nova parte composta à parte"305. Ao contrário, pois, de se referirem a um sistema mecanicista clássico, em que as partes determinam o todo e, por sua vez, o todo determina as partes, os objetos parciais (as caixas, os vasos) concernem a uma relação em que o todo é apenas uma parte ao lado das partes, coexistindo com elas, sendo ele mesmo composto à parte. O dinamismo dessa relação partes-todo, que é pensada por agora como uma afirmação da multiplicidade, não redutível, portanto, a qualquer fixidez fotográfica, dialoga intimamente com uma ideia-cinema em estado bruto; mas insalubre é dizer que alguém, por conveniência, pode chamar determinado fluxo de água de rio Amazonas ou de rio Nilo, da mesma forma que alguém recebe o nome Deleuze ou Proust, pois tal fluxo, pensado em si

\footnotetext{
303 PS, p. 150 - PS(br), p. 117-118.

304 R-CS, p. 117-118.

305 AE, p. 62.
} 
mesmo, numa visada heraclitiana, não permanece inalterado nem sequer por uma mínima fração de segundo. O sistema de passagem entre as partes fechadas é a dimensão transversal que, superando a verticalidade da hierarquização, onde o todo simplesmente fala por todas as partes, e a horizontalidade da semelhança, onde uma parte simplesmente reflete outra parte, está sempre em processo, em movimento, percorrendo os lados, indo de parte em parte. Em outras palavras, a transversalidade aponta para a interpenetração e para o entrelaçamento de mobilidades contíguas, afetada de graus, níveis, coeficientes (por exemplo, a fotografia do falecido Sr. Vinteuil em contiguidade com os entretenimentos sexuais de sua filha). A belíssima cena do trem (em que o narrador corre de uma janela à outra procurando distinguir a paisagem) oferece o melhor exemplo: de modo que eu passava o tempo a correr de uma janela a outra, para aproximar, enquadrar os fragmentos intermitentes e opostos de minha bela manhã escarlate e inconstante e dela ter uma visão total e um quadro contínuo ${ }^{306}$. Nela, a dimensão transversal é exatamente o que faz com que os diversos pontos de vista da paisagem se comuniquem, mas sem lhes suprimir a diferença, sem unificá-los, isto é, mantendo-os não comunicantes segundo as suas próprias dimensões.

Os vasos fechados se atêm a suas vizinhanças pela força de não-comunicação que mantêm em si; isso não deixa de ser perturbador quando o leitor regressa à obviedade de que a Recherche repousa numa voz narrativa, que a seu fio de voz tudo se prende; na verdade, manifesta-se por ela uma operação que consiste em eleger ou escolher um vaso fechado, já com o "eu" nele contido; é que em cada vaso existe um "eu" que vive, que deseja, que se recorda, que vela, que morre, que revive; assim, o fracionamento de Albertine em "dez Albertines" corresponde a uma contiguidade de "eus" não comunicantes na amada. Porém, sob a forma mais pura, essa atividade de eleição ou escolha se exerce, segundo a complicação deleuze-proustiana, no momento de despertar, "quando o sono fez girar todos os vasos fechados, todas as peças cerradas, todos os eus sequestrados, frequentados por quem dorme" ${ }^{307}$; agora, trata-se de uma operação bastante diferente, espremida entre os compartimentos do sono que giram aos olhos do insone. Poulet, num estudo que, por causa e efeito, distingue-se gravemente de Proust et les signes, descreve com perícia alguns dos dilemas contidos na travessia entre o sono e o despertar proustiano; sua ideia é a de que a "busca pelo passado" se inicia no primeiro momento da narrativa, quando o herói, desperto

\footnotetext{
306 R-MF, p. 500.

${ }^{307}$ PS, p. 154 - PS(br), p. 121.
} 
em plena noite, pergunta-se a que época de sua vida se vincula esse momento em que recobra a consciência: "O ser que desperta, e que retoma consciência de sua existência ao despertar, retoma consciência de um lapso de vida singular e tragicamente contraído. Quem é ele? Não sabe mais, e não sabe porque perdeu o meio de ligar o lugar e o momento em que vive a todos

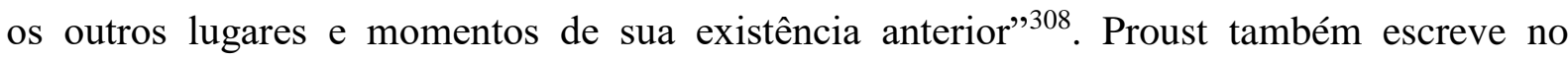
prefácio de Contre Sainte-Beuve a seguinte avaliação: "Por um momento, achei-me na situação de alguém que adormeceu e, ao despertar no meio da noite, não sabe onde está, esforçando-se em orientar o corpo para tomar consciência do lugar em que se encontra, não reconhecendo em que leito, em que casa, em que lugar da terra, em que ano da vida encontrase" 309 . O problema proustiano, contudo, ainda que não apartado das diretrizes de lugares e momentos, não se situa exatamente numa suposta irregularidade entre elementos do passado e do presente, mas na própria desigualdade que existe entre a dimensão irreal do sono e a dimensão real da vigília, quando a atividade de eleição ou escolha se dramatiza no "eu" que se redescobre entre todos os "eus" que ele acabou de ser em sonho, uma espécie de "nós". Às cegas, às escuras, nas tramoias intermediárias do sono, semissono ou semidespertar, há a exigência de um "puro interpretar", de um "puro escolher"; já não é possível falar neste caso de um "eu" que escolhe, visto que, antes de tudo, ele é escolhido na própria experiência de redescoberta: eis por que a atividade de eleição ou escolha assume aqui a sua forma mais pura, sem sujeito. Uma longa passagem de Le côté de Guermantes supostamente oferece a chave para essa desaparição ou inexistência do "eu" que escolhe. Diz-se, em seu primeiro momento: Chama-se a isto um sono de chumbo, e parece que nós mesmos nos tornamos, durante alguns momentos depois que um tal sono terminou, simples bonecos de chumbo. Não somos mais ninguém. Diz-se, em seu segundo momento: Na verdade houve morte [...] A ressurreição ao despertar - após esse benéfico acesso de alienação mental que é o sono deve, no fundo, assemelhar-se ao que ocorre quando se encontra um nome, um verso ou um refrão esquecido ${ }^{310}$. Em Proust, o sono é pensado, pois, como uma benéfica alienação mental, enquanto que o ato de despertar é pensado como uma ressurreição; isso dispara, enfim, na formulação deleuze-proustiana, a ideia de um "puro interpretar", que não tem no "eu" o seu sujeito: “O 'sujeito` da Recherche não é, finalmente, nenhum eu, é esse nós sem conteúdo que

\footnotetext{
308 Georges Poulet (1992, p. 14).

${ }^{309}$ Marcel Proust (1988, p. 42).

${ }^{310}$ R-CG, p. 76-77.
} 
distribui Swann, o narrador, Charlus, e os distribui ou os escolhe sem totalizá-los" ${ }^{311}$. No limite, é sempre numa dimensão de transversalidade que a unidade ou a totalidade se organiza por si mesma sem unificar ou totalizar os sujeitos.

Em segundo lugar, o mundo dos signos se opõe ao logos do ponto de vista da natureza da lei que os signos revelam. Em relação ao mundo grego, tem-se uma profunda transformação da lei, dinamizada agora segundo a consciência moderna do antilogos: em Proust, ao invés de uma lei que rege fragmentos adaptáveis, aproximando-os, reunindo-os, segundo o estabelecimento do melhor relativo, há uma lei primariamente desconhecida que rege fragmentos não totalizáveis, separando-os, compartimentando-os, segundo o estabelecimento da não-comensurabilidade no continente (caixas entreabertas) e da nãocomunicação no contíguo (vasos fechados); mais do que isso, em Proust ou em Kafka, ao invés de leis especificadas desta ou daquela maneira, como um j'accuse, permitindo conhecer alguma coisa que as ultrapassa, a saber, a figura do "melhor", o aspecto que o Bem toma no logos, há simplesmente a lei, sem descrição, vazia, formal, não tendo o Bem como referência. Deste modo, a nova natureza da lei não permite a antecipação de seus índices, não possibilita prévios conhecimentos, inviabiliza obediências; para alguém saber o que a lei delibera, recebe antes a punição, o que significa responder à lei já como culpado: "Estritamente incognoscível, a lei só se dá a conhecer quando se aplicam as mais duras sanções ao nosso corpo supliciado" 312 . O tema da culpabilidade desempenha um papel razoavelmente relevante na obra de Proust; o universo das relações afetivas e das responsabilidades pessoais volta e meia se marca pela ideia da culpa; todas as personagens são, desigualmente, de uma forma ou de outra, culpadas; o narrador-herói comumente faz associações diretas ou indiretas sobre o assunto, chegando às vezes a alguns painéis de culpas similares, como faz ao comparar a morte da avó com a de Albertine: Nesses momentos, aproximando a morte de minha avó à de Albertine, tinha a impressão de que minha vida estava manchada por um duplo assassinato que somente a covardia da sociedade poderia me perdoar ${ }^{313}$. No entanto, como afirmam Deleuze e Guattari em L'Anti-Oedipe, essas confissões de culpabilidade na Recherche só aparecem "para fazer rir", visto que a lei é primariamente desconhecida, nunca se antecipando

\footnotetext{
311 PS, p. $156-$ PS(br), p. 122.

312 PS, p. $159-$ PS(br), p. 125.

${ }^{313}$ R-AF, p. 374.
} 
como uno ou todo: "os rigores da lei só aparentemente exprimem o protesto do Uno, e encontram, ao contrário, seu verdadeiro objeto na absolvição dos universos fragmentados, nos quais a lei nada reúne no Todo" 314 . É possível notar, aliás, segundo Deleuze com Proust, uma singela diferença entre a culpabilidade kafkiana e a culpabilidade proustiana: no primeiro caso, que é uma forma particularmente aguda, com tons mais noturnos, a culpabilidade aparece explicitamente como uma sanção, em O processo, Na colônia penal ou A muralha da China, enunciada numa sentença que só pode ser conhecida por meio do castigo, constituindo uma "consciência depressiva da lei"; no segundo caso, a culpabilidade é, antes de tudo, antes mesmo de aparecer como uma sanção, a aparência que oculta uma realidade fragmentária mais profunda, constituindo uma "consciência esquizoide da lei".

A formulação conceitual lei-culpa não deixa de aparecer por vidros e coitos nas obras de Deleuze e Deleuze-Guattari, seja com a própria filosofia (especialmente, com Platão, Kant e Nietzsche), seja com a não-filosofia (especialmente, com Proust, Sacher Masoch, Kafka, Melville e Artaud); porém, são as literaturas kafkiana e proustiana, tomadas como máquinas anelares da consciência moderna, a válvula que dispara e fomenta os seus principais trânsitos. Em Kafka: pour une littérature mineure, a questão se desenvolve em torno do funcionamento da obra: Kafka se inscreve na transposição da concepção grega à concepção judeu-cristã da lei, mas o seu humor, entendido por Deleuze e Guattari como um elemento decisivo, investe, paradoxalmente, no estabelecimento de uma lei transcendental que é apenas funcional; o que existe nele é a desmontagem do mecanismo de uma máquina diferente, "que só necessita desta imagem da lei para afinar as suas engrenagens e fazê-las funcionar em conjunto" 315 ; no instante em que a imagem da lei transcendental desaparece, a máquina se desmonta, as peças se dispersam, a culpabilidade cai no ridículo. Essa lei funcional não é do domínio do conhecimento, mas do domínio da necessidade prática; como imagem transcendente, ela assimila certa relação com a culpa; ou seja, a culpabilidade é um a priori que corresponde à transcendência, despejada absoluta e inadvertidamente sobre culpados ou inocentes; na operação, a inscrição da lei se faz nas superfícies do real, no próprio corpo, na própria carne; assim, em $\mathrm{Na}$ colônia penal, onde se observa a ideia de culpa inequívoca e a aplicação da punição exemplar, o condenado só conhece a sentença da lei pelas chagas resultantes do suplício: “- Ele não conhece a própria sentença? [...] - Seria inútil anunciá-la. Ele vai

\footnotetext{
${ }^{314}$ AE, p. 63.

${ }^{315}$ K, p. 80.
} 
experimentar na própria carne" ${ }^{316}$. Em Proust et les signes, por sua vez, a questão se desenvolve em torno das experiências amorosas; na Recherche, o amor é uma declaração de inocência somente imaginária, pois a culpabilidade já reside em tudo o que o condiciona (culpa original ou natural), além de estar presente nas percepções que depois incrementam o seu término; de fato, a culpabilidade da amada é um a priori que o amante demarca em toda a sua experiência, como se pode ver no seguinte trecho sobre as mulheres: Aliás, mais até do que as culpas do tempo em que as amamos, existem as culpas de antes que as conhecêssemos, e a primeira de todas: a sua natureza $a^{317}$. Todavia, como já foi dito, as experiências amorosas se manifestam numa complexidade que se articula em três níveis sexuais: intersexualidade, homossexualidade e transexualidade. Deleuze e Guattari retomam essa questão em $L^{\prime}$ AntiOedipe: "somos heterossexuais estatisticamente ou molarmente, mas homossexuais pessoalmente, quer o saibamos ou não, e, por fim, transexuados elementarmente, molecularmente" ${ }^{318}$. É no nível da homossexualidade proustiana, quando o conjunto dos amores intersexuais aparece dividido entre Sodoma, escondendo o segredo cada vez mais oculto do amante, e Gomorra, escondendo o segredo cada vez mais revelado da amada, que impera efetivamente uma ideia de falta ou culpa; o problema é que essa culpabilidade homossexual permanece na superficialidade, demasiadamente estatística, mais social do que moral, mais projetada sobre os outros do que interiorizada pelo narrador, respondendo a uma lei primariamente incognoscível. De pronto, o que mais interessa para a complicação deleuzeproustiana é todo um sistema de contiguidades, compartimentalizações e estranhas comunicações que se desperta, mais propriamente, no terceiro nível da sexualidade proustiana, o da coexistência de dois sexos num mesmo sexo, o hermafrodita original, como uma realidade fragmentária mais profunda. A transexualidade é compreendida à luz da nova lei da consciência moderna, opondo-se ao logos, visto que as lendárias páginas de Sodome et Gomorrhe combinam muitos elementos incombináveis. Por um lado, dois temas abertamente contraditórios se entrelaçam, entram em comunicação aberrante, segundo uma dimensão transversal: a culpabilidade fundamental dos homossexuais e a inocência radical das flores. Eis Deleuze e Guattari o que dizem em L’Anti-Oedipe: "o tema aparente da culpabilidade se entrelaça com um outro tema que o nega, o da ingenuidade vegetal na compartimentação dos

\footnotetext{
${ }^{316}$ Franz Kafka (1998, p. 36).

317 R-AP, p. 114.

318 AE, p. 97.
} 
sexos"319. Por outro lado, na metáfora vegetal, onde se hospeda o nível mais espesso da teoria proustiana, tudo remete à coexistência de objetos parciais num mesmo indivíduo; em essência, eles não se comunicam, exigindo a atuação de um intermediário, o inseto, para assegurar a aliança entre macho e fêmea; o intermediário revela uma passagem, a transversal, que só pode operar uma comunicação aberrante entre os sexos compartimentados.

Existe uma competência especial entre o ciúme, que é a finalidade ou a destinação do amor, e os três níveis da sexualidade: o ciúme envolve a descoberta de que os mundos desconhecidos dos amados excluem os amantes, integrando-os na paisagem e nas circunvizinhanças apenas de um ponto de vista impenetrável em que a paisagem e as circunvizinhanças se organizam segundo a lógica dos próprios amados; o ciúme envolve a descoberta dos mundos desconhecidos que se desenvolvem nas séries homossexuais (Sodoma e Gomorra), fontes de prazeres vistos como incognoscíveis e impraticáveis; enfim, o ciúme envolve a descoberta da transexualidade do seres amados, tudo o que se oculta ao lado dos sexos aparente e globalmente determinados. Em última instância, há uma trindade que resume toda a lei do amor proustiano: sequestro, voyeurismo e profanação. Sequestrar significa esvaziar os seres amados de todos os mundos desconhecidos, justamente para melhor decifrálos, explicá-los, mas também fazer com que esses mundos desconhecidos se relacionem com um ponto de envolvimento entre os amantes; significa cortar as séries homossexuais que constituem esses mundos desconhecidos, mas também descobrir a homossexualidade como o pecado original ou natural dos amados; significa, enfim, impedir os lados contíguos, sexos ou objetos parciais de se comunicarem na dimensão transversal frequentada pelo intermediário, o inseto, fechando-os em si mesmos, mas também deixá-los numa possibilidade de comunicação, numa potencialidade de comunicação que, no final das contas, sempre surpreende por conta dos acasos, o segredo de todos os signos, despistando quaisquer previsões ou pressuposições. Ver significa ver sem ser visto, eliminando o risco de ser dominado pelo ponto de vista do outro, mas também se permitir a um deleite que só pode ocorrer num envolvimento com o outro, como acontece quando o narrador vê Albertine dormir; significa dividir entre Sodoma e Gomorra a homossexualidade global e específica, fundada na independência dos sexos ou das séries, mas também descobrir enquanto transexualidade uma homossexualidade local e não específica, fundada na compartimentação contígua dos sexos ou objetos parciais; significa, enfim, reduzir os amados a objetos parciais

319 AE, p. 63. 
não comunicantes, mas também viabilizar o modo de comunicação transversal que essas metades compartimentadas podem criar, lados contíguos que devem se comunicar transversalmente, inserindo à força em determinado mundo o fragmento de outro mundo. Daí a importância que o tema da profanação tem na obra de Proust, empreendido tanto nas experiências amorosas quanto em outras frentes, com a conjugação de fragmentos apenas transversalmente comunicantes, num tipo de técnica geral de contiguidades, compartimentalizações e estranhas comunicações entre vasos fechados. Por exemplo, em $D u$ côté de chez Swann, no episódio de Montjouvain, é a profanação sádica o que articula a fotografia do Sr. Vinteuil recentemente morto e os prazeres sexuais da Srta. Vinteuil com uma amiga; isso não à toa, sugere Deleuze com Proust: "profanar é fazer a mãe (ou o pai) funcionar como objeto parcial, isto é, compartimentá-la, fazê-la ver um espetáculo contíguo, e até mesmo fazê-la atuar nesse espetáculo, que ela não pode mais interromper e do qual ela não pode mais escapar, fazê-la juntar-se ao espetáculo" ${ }^{320}$. A lei do amor proustiano, dando-se a conhecer quando aplica as mais duras sanções, tendo no ciúme o delírio próprio dos signos, resume-se, assim, em sequestro, voyeurismo e profanação: ser duro e pérfido com os seres amados, vê-los sem ser visto, envolvê-los em cenas compartimentadas nas quais se esboça e se instaura não mais do que um acoplamento aberrante.

Em terceiro lugar, o mundo dos signos se opõe ao logos do ponto de vista do uso das faculdades que os signos requerem. No acaso dos encontros, cada signo aciona uma faculdade (inteligência, memória, imaginação, pensamento puro), constituindo então o interpretar, uma produção de sentido/verdade (leis gerais ou essências singulares); considerados esses meios e modos, que são apropriadamente os de uma nova imagem do pensamento, tal produção da verdade detém "a profundidade e a obscuridade do involuntário" ${ }^{321}$. E existem ordens de produção dessa verdade, como máquinas de produção, não bastando dizer que competem as verdades de um tempo plural (grande quociente entre o perdido e o redescoberto, cada qual com as suas verdades). É que a sistematização final de Proust sugere, entre as duas grandes categorias do tempo, três ordens ou máquinas de verdades, todas dizendo respeito, para mais ou para menos, à questão da produção da obra de arte: "máquina de objetos parciais", “máquina de ressonância" e "máquina de movimento forçado". A primeira é a máquina dos

\footnotetext{
320 PS, p. 170 - PS(br), p. 134.

321 PS, p. 177 - PS(br), p. 139.
} 
prazeres e dos sofrimentos não plenos (signos mundanos e amorosos), que se confunde com o fluxo do tempo perdido, produzindo verdades parciais, apenas secundárias; a segunda é a máquina das reminiscências e das essências singulares (signos sensíveis e artísticos), que se confunde justamente com o fluxo do tempo redescoberto, produzindo efeitos de ressonância; a terceira, enfim, é a máquina da universal alteração (signos do envelhecimento e da morte), que, semelhantemente à primeira máquina, confunde-se com o fluxo do tempo perdido, mas produzindo um movimento forçado. Em Le temps retrouvé, a determinação dos temas e o movimento do texto são o que distingue essas três máquinas. Do ponto de vista dos temas, na primeira máquina está tudo aquilo que obedece a leis gerais (generalidade de grupo, para a vida mundana; generalidade de série, para os amores), na segunda máquina está tudo aquilo que se marca pelas reminiscências e essências singulares, na terceira máquina está tudo aquilo que se define pela ideia de morte. Do ponto de vista do movimento do texto, as verdades da máquina de objetos parciais secundam as verdades da máquina de ressonância, dando-lhes uma espécie de contraditório, enquanto que as verdades da máquina de movimento forçado vêm cimentar as verdades da máquina de ressonância, não sem antes lhes opor uma verdadeira objeção, que só pode ser superada quando a ideia de morte encontra lugar na própria obra de arte. Mais uma vez, o problema deleuze-proustiano não se resume em analisar elementos de narratividade que se depõem na suposta sistematização proustiana; a questão decisiva é construir uma rede de animação conceitual que, disparada e fomentada pelos processos literários, permite articular nesse instante certas noções não primariamente interagentes (do ponto de vista dos temas) e primariamente interagentes (do ponto de vista do movimento do texto), como as noções de parcialidade, ressonância e movimento forçado, até atingir novamente a questão da transversalidade; desnecessário é sublinhar que, segundo essa abordagem, as três máquinas estão tramadas por um pensamento que dedica ao uso involuntaríssimo das faculdades, conforme o acaso dos encontros e a pressão das coações, toda a possibilidade de suas operações maquínicas, o que implica romper, em última instância, com qualquer concepção lógica e orgânica da arte.

A máquina de objetos parciais (fragmentos sem totalidade, partes divididas, vasos sem comunicação, cenas compartimentadas) agrupa os valores da mundanidade, do amor e até mesmo dos sonhos, valores que fazem parte do aprendizado. Os signos mundanos e amorosos são extremamente diferentes, mas há entre eles o âmbito comum da inteligência involuntária, que é a faculdade que os desenvolve; ela expõe as leis gerais, de grupo ou de série, que neles 
se encarnam: na mundanidade, conhecer determinado grupo social é saber interpretar os gestos, as frases e os sentimentos que assinalam a existência de leis gerais de grupo; no amor, a série de amores sucessivos (a mãe, Gilberte, a duquesa de Guermantes, Albertine), a série particular, formada em cada experiência amorosa (Albertine é Albertines), e a série transubjetiva, encadeando séries com séries (Albertines com Odettes), assinalam a existência de leis gerais de série. Contudo, as verdades da inteligência involuntária não se confortam nesse circuito ainda superficial ou plano, que ilumina somente a epiderme das operações; na prática final, compreendidas em suas manobras mais profundas, as leis gerais determinam, ao cabo de seus paroxismos, irremediáveis distâncias, afastamentos, compartimentações: "a ideia de lei geral, em Proust, é inseparável da produção de objetos parciais e da produção das verdades de grupo ou das verdades de série correspondentes" ${ }^{\text {"22 }}$. É assim que, no material mundano, destacam-se, por exemplo, como instâncias distantes ou separadas, o movimento dos ombros de uma pessoa e o movimento do pescoço de outra pessoa; por mais que os minúsculos deslocamentos dos corpos correspondam a leis gerais de grupo, muitas vezes em sintonia com mil convencionalismos, modismos e esnobismos, não existe nas redes expositivas dessa administração uma totalização dos gestos, mas uma compartimentalização que simplesmente os coloca lado a lado, como objetos parciais; com mais razão, no material amoroso, persevera aquela coexistência de objetos parciais no mesmo indivíduo, o hermafrodita original. Mas é devido dizer que nas malhas nocionais da parcialidade também se inserem os valores do sonho, por sua capacidade de mostrar os fragmentos como que através de um telescópio; por exemplo, as pessoas sonhadas perdem qualquer caráter global, sendo tratadas como objetos parciais, seja porque apenas uma parte delas é destacada, seja porque elas mesmas assim funcionam inteiramente; o sonho, aliás, insubmisso a qualquer esquema mensurável, implica um estupendo jogo com o tempo, podendo transpor, sem anulálas, épocas resolutamente fragmentadas, separadas por distâncias enormes ${ }^{323}$.

Já a máquina de ressonância diz respeito às impressões sensíveis e à arte, produzindo efeitos de ressonância secundados pela produção de objetos parciais, como é possível ver no final da Recherche, na casa da Sra. de Guermantes. Essa ordem ou máquina de verdade se distingue pelas faculdades nela acionadas (memória involuntária ou imaginação e pensamento puro), mas também pela qualidade de seu produto: no caso dos signos sensíveis, uma

\footnotetext{
322 PS, p. 181 - PS(br), p. 143.

${ }^{323}$ R-TR, p. 695.
} 
"essência local”, remetendo, por exemplo, a Combray, Veneza ou Balbec; no caso dos signos artísticos, uma "essência individualizante", constituindo os mundos expressos no campo artístico. Entre os efeitos de ressonância, os mais célebres são os da memória involuntária, êxtases que se multiplicam subitamente em Le temps retrouvé (as pedras do calçamento, o barulho de uma colher, o guardanapo), como se a máquina aí se revelasse a todo vapor; tratase sempre da produção de um ponto de vista superior a dois momentos que ressoam, um atual e um antigo, em ruptura com a ideia de uma simples cadeia subjetiva. Mas o que é verdadeiramente novo em Proust, o que faz da madeleine ou dos campanários de Martinville um permanente sucesso, é que esses instantes se tornam "o efeito de uma máquina literária", para além da maneira original ou do estilo peculiar com que eles são apresentados e analisados: "Não mais se trata de uma experiência extraliterária que o homem de letras relata ou de que se aproveita, mas de uma experimentação artística produzida pela literatura, de um efeito de literatura, no sentido em que se fala de um efeito elétrico, eletromagnético etc" ${ }^{324}$. A questão é similar à do desenho de pensamento jazzístico: mais do que uma mera tematização (explicação, ideia-foto, temas melódicos), uma verdadeira prática, um funcionamento (experiência, ideia-cinema, improvisações). Com efeito, sem se desprezar a imperiosa necessidade de se aplicar alguns ajustes nocionais e expressivos, semelhante é a dinâmica funcional invariavelmente desejada e perseguida na arte: "É a obra de arte que produz em si mesma e sobre si mesma seus próprios efeitos, e deles se sacia, deles se nutre: ela se alimenta das verdades que ela engendra" "325. Na Recherche, os instantes de ressonância como êxtases são tanto um "efeito estético" (instrumento de ótica para os leitores) quanto um "efeito artístico" (instrumento de ótica para a própria busca); a obra de arte já em andamento, esse instrumento de que Proust se serve ao mesmo tempo que o fabrica, é o único meio de converter as experiências sensíveis da memória involuntária num equivalente espiritual ${ }^{326}$; o que se produz não é simplesmente a interpretação dos fenômenos de ressonância, mas algo de natureza muito diferente, isto é, tudo o que pertence à essência artista (essa pátria desconhecida, por assim dizer, não fotografável), revelando-se como diferença última absoluta.

Enfim, a máquina de movimento forçado corresponde aos signos do envelhecimento e da morte. No palácio de Guermantes, o narrador vê uma espécie de desfile de corpos

\footnotetext{
${ }^{324}$ PS, p. 184 - PS(br), p. 145.

325 PS, p. 185 - PS(br), p. 145.

${ }^{326}$ R-TR, p. 671.
} 
agonizantes, semimortos ou com os pés na cova, um espantoso espetáculo que, por conta da passagem do tempo, apresenta-se em rostos surpreendentemente enrugados, envelhecidos. Essa ordem ou máquina de verdade se expressa, portanto, pela ideia de morte: "Em toda a parte a proximidade da morte, o sentimento da presença de uma 'coisa terrível', a impressão de um fim último ou mesmo de uma catástrofe final em um mundo deslocado que não é apenas regido pelo esquecimento, mas corroído pelo tempo"327. Ela suscita mais problemas quando parece estar inserida nas duas máquinas anteriores: vigilante já em certos amores (Albertine) e em certos êxtases (a botina e a lembrança da avó), experiências assombradas pela morte. Nesse ponto, há uma contradição a ser superada entre as três ordens ou máquinas: "as duas primeiras ordens eram produtivas e, assim, sua conciliação não colocava problema particular; mas a terceira, dominada pela ideia de morte, parece absolutamente catastrófica e improdutiva" 328 . Em outras palavras, os objetos parciais e os efeitos de ressonância, ainda que por vezes entremeados por sombras, não traziam a ideia de morte como um problema decisivo, situação bastante distinta do que agora se impõe. É em torno dessa contradição que se deve entender o notável apontamento de Proust sobre a "mais grave das objeções" contra o seu empreendimento literário (a obra a ser escrita): Com efeito, logo que entrei no grande salão, conquanto sempre mantivesse firme em mim, no ponto em que me achava, o projeto recém-formado, deu-se um lance teatral que ergueria contra minha empreitada a mais grave das objeções ${ }^{329}$. O que se segue é o relato do famoso jantar, com a impotência e a hesitação do herói em reconhecer os convidados, já que todos estão irreconhecíveis ou, mais propriamente, desconhecíveis, como que transformados e disfarçados pelos anos, atingidos pelos golpes cruéis do envelhecimento; como afirma Ricoeur, referindo-se a essa cena, "o trabalho de reconhecimento está assim frente a frente com o temor do 'desconhecível " "330; um dos convidados, relata Proust, deixara crescer uma barba branca e, arrastando os pés, tornando-os pesados como se usassem solas de chumbo, parecia ter-se encarregado de representar uma das "fases da vida"331; no quadro das afetações físicas, sobejam inabilidades motoras, caducidades, manchas de pele, buracos faciais, membros e órgãos capengas, além de roupas desengonçadas e maquiagens chinfrins. É uma máquina de movimento forçado essa

\footnotetext{
${ }^{327}$ PS, p. 188 - PS(br), p. 148.

328 PS, p. 190 - PS(br), p. 150.

329 R-TR, p. 701.

${ }^{330}$ Paul Ricoeur (2006, p. 80).

331 R-TR, p. 702.
} 
máquina: o movimento do tempo, do passado para o presente, do estado antigo de uma pessoa para o seu estado atual, "se duplica em um movimento forçado de maior amplitude, em sentido inverso, que varre os dois momentos, ressalta o intervalo entre eles e faz recuar o passado" 332 . Em outras palavras, a impressão de envelhecimento de uma pessoa funciona numa operação de dilatação do tempo: o estado antigo dessa pessoa se torna ainda mais antigo, mais recuado, como que se situando num passado muitíssimo remoto, longínquo, quase inverossímil; a amplitude desmesurada do tempo se coloca como se tivessem corridos verdadeiros períodos geológicos. Evidentemente, a grande "objeção" reside no fato de que o espetáculo dos estragos corporais, esculpindo sem reticências ou reservas a decrepitude, repercute como um bumerangue nas intenções do próprio empreendedor; a ideia de morte, não mais suportável pela indiferença, desnuda agora a hipótese de uma severa falência, o risco de o projeto de escrita nunca se efetivar, tornar-se em algum instante empreendimento impedido ou abortado, irrecuperavelmente dissolvido pela espada apressada do trespasse. Tal objeção só pode ser superada quando a ideia de morte encontra lugar na própria obra de arte, isto é, quando as verdades da máquina de movimento forçado vêm cimentar as verdades da máquina de ressonância ou, dizendo de outra maneira, quando a contradição entre o tempo perdido e o tempo redescoberto se resolve na ordem de produção do próprio livro, em sua estrutura formal.

Em quarto e quinto lugar, o mundo dos signos se opõe ao logos do ponto de vista da unidade muitíssimo especial que deles decorre e da estrutura da linguagem que os traduz e interpreta. As ordens de verdade não têm função de totalização, permanecendo fragmentadas, sem que nada lhes falte; já Vermeer e Vinteuil não valiam pelo todo, mas pelo pequeno lanço de muro amarelo e pela pequena frase musical, cada qual contendo o mundo inteiro em seu fundo sombrio; de pronto, não se apresenta qualquer unidade prévia das partes. Se ainda insiste ou subsiste o problema do par uno-múltiplo, o uno só pode ser pensado como efeito do múltiplo: "um Uno e um Todo que não seriam princípio, mas, ao contrário, o 'efeito ' do múltiplo e de suas partes fragmentadas; Uno e Todo que funcionariam como efeito, efeito de máquinas, ao invés de agirem como princípios" ${ }^{333}$. Deleuze com Proust está a favor e contra Leibniz: conexão, no ponto específico das mônadas, dada a formulação leibniziana sobre as

\footnotetext{
332 PS, p. 191 - PS(br), p. 150.

${ }^{333}$ PS, p. 195-196 - PS(br), p. 155.
} 
unidades irredutíveis e fechadas; desconexão, dada a restauração leibniziana de uma unidade ou totalidade prévia entre as mônadas. É que Leibniz, ao formular o problema filosófico da comunicação entre as partes isoladas, não deixou de se resolver numa divinizada universalidade, como um coup de grâce: as mônadas, que são substâncias simples e, consequentemente, privadas de extensão e divisibilidade, arrumam-se em relação a uma totalidade que previamente lhes fornece harmonia; portanto, é uma unidade anterior, sob a forma de Deus, o que estabelece toda a correspondência entre as mônadas. A ideia do uno como efeito do múltiplo, ao contrário, implica que a unidade ou totalidade resulta de uma multiplicidade especial que não forma nem supõe um uno ou um todo como princípio; portanto, unidade ou totalidade também especial: não premeditada nem pressuposta, não de origem nem de destinação, não lógica nem orgânica. À complicação deleuze-proustiana é suficiente a percepção proustiana em La prisonnière sobre a unidade ulterior, não artificial, nos romances de Balzac: nele, dispensadas seriam aquelas sistematizações de escritores mediocres que, com grande reforço de títulos e subtítulos, desejam parecer que se deram ao esforço de perseguir um só e transcendente desígnio; nele, a unidade seria não fictícia, talvez mais real até por ser ulterior, por ter nascido de um momento de entusiasmo em que é descoberta entre pedaços que só precisam se unir, unidade que se ignorava, portanto vital e não lógica, que não proscreveu a variedade nem ressecou a execução; nele, a unidade seria como determinado trecho composto à parte, nasceu de uma inspiração, não exigida pelo desenvolvimento artificial de uma tese, e que vem integrar-se ao resto ${ }^{334}$. Tal percepção certamente realça, por uma série de subtendidas oposições, a cinematografia do pensamento balzaquiano: ao esforço voluntarioso de perseguir um só e transcendente desígnio (ideia-foto) se opõe a nervura espontânea da flutuação (ideia-cinema); ao bloco imóvel das ideias (ideiafoto) se opõe o estágio perspectivo que não pode proscrever a variedade nem ressecar a execução (ideia-cinema); à harmonia antecipada das partes (ideia-foto) se opõe a posteridade e a estrangeirice impensada de um trecho composto à parte (ideia-cinema). Aqui, contudo, não arvora Deleuze com Proust a pretensão de finalizar o problema da unidade posterior (efeito do múltiplo) sem modular a questão da "estrutura formal da obra de arte", seja por enfrentar o âmbito da explicação de qualquer construção, a sua própria, visto que também se debate para a objetividade das formulações, seja por enfrentar o âmbito da experiência de qualquer construção, a sua própria, visto que também se lança para aquele estágio perspectivo

334 R-AP, p. 122. 
que não resseca a execução; o composto reclama, então, imediatamente, a questão do estilo, transmutada agora para uma face bem distante daquele estilo-essência que aparecia em "Os signos".

É devido passar por Proust sobre Flaubert e Balzac para se chegar nesse Deleuze com Proust, e bem possível será dizer que Balzac, de certo modo, não tem estilo. O Proust théoricien de Contre Sainte-Beuve discorre sobre o estilo sem estilo balzaquiano, um nãoestilo, contrastando-o com o estilo predominantemente fotográfico de Flaubert, que se apresenta bastante compactado: "Em Balzac, pelo contrário, coexistem, não digeridos, ainda não transformados, todos os elementos de um estilo por vir, que não existe" ${ }^{335}$. As partes flaubertianas estão de antemão aplanadas, como superfícies refletoras ou sugestivas de uma verdade segura, convertidas então numa substância homogênea, sem impureza; é que elas ainda se apoiam numa espécie de estilo-logos persistente e conservado, não atravessadas pelo caos; em Balzac, longe disso, as partes se distribuem e permanecem na fragmentação, não equalizadas, não filtradas, não fundidas, ainda que se deixando compreender - como pode ocorrer com as partes de qualquer conversação, desde que seja uma "conversação genial". Esse não-estilo balzaquiano não sugere nem reflete, apenas explica, com a ajuda de imagens intensas, "mas não fundidas com o resto": eis a despreocupação com a harmonia do todo. Do mesmo modo, bem possível será dizer que Proust não tem estilo. No Proust et les signes, apreende-se a ideia de que as partes proustianas não se deixam ajustar, não se desenvolvem com os mesmos traços e valem por sua singularidade, tal qual o muro de Vermeer ou a frase de Vinteuil; como diz Godino, num trecho dedicado a esse gradiente conceitual deleuzeproustiano, "são tantos os meandros que é necessário recolher cada pequeno fragmento e ajustá-lo à sua velocidade (diferente de todas as outras), cada um derivando/reenviando a uma série diferente ou mesmo a nada"336. As partes se distribuem e permanecem numa fragmentação que somente um uno como efeito do múltiplo pode confirmar (portanto, uno que resulta das partes, em posteridade, sem lhes alterar o caráter fragmentado). Trata-se de um não-estilo esse estilo (ou um estilo antilogos), confundindo-se com o interpretar puro, sem sujeito, sendo explicativo através das imagens mais surpreendentes, multiplicando os pontos de vista sobre a frase, no interior da frase, com numerosos efeitos puzzle de retorces asfixiados em si mesmos: "daí o papel dos incidentes, das subordinadas, das comparações que

\footnotetext{
335 Marcel Proust (1988, p. 103).

336 Ana Godino (2007, p. 41).
} 
exprimem numa imagem esse processo de explicação, a imagem sendo boa se ela explica bem, sempre explosiva, sem nunca se sacrificar à pretensa beleza do conjunto" 337 . Evidentemente, as explicações que constituem esse não-estilo proustiano são, por assim dizer, explicações muito experienciais, lambuzadas fortemente por uma ideia-cinema; elas não têm intenção didática, funcionando, na verdade, como uma potente máquina de emaranhar, embobinar ou espiralar as coisas (objetos parciais, efeitos de ressonância, movimentos forçados); em última instância, elas não garantem unidade. O que, então, nesse mundo em frangalhos, de fragmentos intermitentes ou desconexos, pode servir de unidade? Deleuze com Proust responde que somente a "estrutura formal da obra de arte" pode servir de unidade e fornecer às partes do não-estilo a chave de seus próprios estilhaços. Essa estrutura formal não é outra coisa senão a dimensão transversal, aquele já referido sistema aberrante de passagem, percorrendo os lados, indo de parte em parte ou de frase em frase, zona do inseto intermediário dos sexos em si mesmos compartimentados, apontando para a interpenetração e para o entrelaçamento de mobilidades contíguas, transbordando-se até mesmo para além do próprio livro (unindo-o, por exemplo, a um Balzac). Afirmando os pedaços disparatados, mantendo-os, portanto, ainda não comunicantes segundo as suas próprias dimensões, a transversalidade é, enfim, a estrutura formal que garante a unidade posterior como efeito do múltiplo, uma espécie de trecho composto à parte, assegurando a imanência do um ao múltiplo e do múltiplo ao um.

${ }^{337}$ PS, p. 199 - PS(br), p. 158. 


\section{Cinco}

A complicação deleuze-proustiana, nas duas partes de Proust et les signes, é um horizonte de incidência e emergência de ideias sobre a questão do pensamento; não exclusivamente sobre a questão do pensamento na Recherche, mas sobre a questão geral do pensamento em si. Em sentido fotográfico, o capítulo "Um" do presente exame se colocou como uma introdução necessária para a compreensão da natureza dessa complicação, dividindo-se em três blocos progressivos (filosofia e criação conceitual, as relações entre filosofia, ciência e arte e, de uma forma mais específica, as relações entre filosofia e literatura); o capítulo "Dois", adentrando-se já na primeira parte de Proust et les signes, procurou recompor o sistema dos signos proustianos (mundanos, amorosos, sensíveis e artísticos) e o conceito de imagem do pensamento; o capítulo "Três", como uma extensão do capítulo anterior, examinou três ideias que se decidem numa dinâmica de encontros e sensações (a ideia do encontro intensivo, a ideia do não-reconhecível e a ideia do acaso), para em seguida discutir o problema da verdade e do aprendizado dos signos, até compactar o sentido de cada signo pelo conceito de essência-diferença; enfim, o capítulo "Quatro", articulando a segunda parte de Proust et les signes com outros textos deleuzianos e deleuzeguattarianos, examinou os cinco pontos de vista pelos quais o mundo dos signos se opõe ao logos (partes, lei, uso, unidade e estilo), deixando-se atravessar pela noção de transversalidade. De fato, o móbile deleuze-proustiano, recheado de vidros e coitos, é um horizonte de incidência de ideias combinadas em duas grandes ordens conceituais: signopensamento e antilogos-transversalidade. A primeira ordem, imbricada no problema da emissão e interpretação dos signos, diz respeito à gênese do pensamento: como surge o pensamento? Isso recebe em "Os signos" a formulação de que pensar não é um ato natural ao pensamento; pensa-se, busca-se a verdade, somente sob a pressão dos signos. A segunda ordem, imbricada no problema da produção e multiplicação dos signos, diz respeito à unidade do antilogos: como um pensamento antilogos, que se organiza na forma de partes primariamente não comunicantes, pode ganhar unidade ou comunicabilidade? Isso recebe em "A máquina literária" a formulação de que a estrutura formal que garante a unidade do pensamento antilogos é a sua dimensão transversal. Porém, esse sentido fotográfico do 
presente exame, que penetra o horizonte de incidência de ideias como que enumerando informações felizes que se recolhem tilintantes numa taça, é somente a sua primeira onda, uma totalidade estatística que não chega à segunda onda, ao seu mundo em processo, em movimento, em cinema; isso ocorre em qualquer sistema de pensamento, servindo para Proust et les signes, para a Recherche ou para o próprio exame que aqui se faz; é bem possível apreender, afinal, que a fotografia não esgota a força de um desenho de pensamento, tampouco revela ou abrange as suas dimensões mais fluentes e gordurosas. Como o pensamento se desenha? Num reducionismo didático, já se apontou e se pulverizou, desde o capítulo "Zero", a hipótese de que qualquer pensamento se desenha pela orientação de uma ideia-foto, que é o âmbito da explicação, da exposição, da informação ou da comunicação (estruturas fixas que funcionam, por assim dizer, como temas melódicos), e pela orientação de uma ideia-cinema, que é o âmbito da experiência, do processo, da flutuação ou do movimento (estruturas móveis que funcionam, por assim dizer, como improvisações jazzísticas). Quid facti (questão de fato), quid juris (questão de direito) e quid vitae (questão de vida): há sempre uma região, disparada e fomentada, em que a incidência não tem mais serventia, não pode mais ajudar, já fez o seu trabalho subterrâneo de terrorismo; enfrenta-se então certo ponto da questão geral do pensamento num estado de ideia-Adão (sem corrimãos, sem pai e mãe), não por algum voluntarismo heroico, não por um oásis de luxe et volupté, mas por uma necessidade emergente, que deriva de uma vibração-mosca nervosa. Por exemplo, não ignorando o fato de que Proust et les signes é também um horizonte de emergência de ideias, o presente exame aqui se examina, pensa sobre o seu próprio desenho de pensamento, em termos de ideia foto-cinema, não obstante haver nisso uma vocação de problema muitíssimo geral.

A ideia-foto é a ideia da explicação laboratorial, com as suas lembranças repisadas e lubrificadas, julgando calafetar ou impermeabilizar todo o abrigo, não sem a expressividade do êxito no qual um fio de prumo deixa a marca do seu equilíbrio. $O$ imóvel que a ideia-foto pensa, com os ecos de Apolo e Parmênides, no espírito da ordem, da racionalidade e da harmonia intelectual, guarda os sepulcros do movimento experiencial: o que pertence à explicação, desmentindo quaisquer derrotas passageiras, não passa de uma recompensa para o que não se diz objetivamente, absolutamente. Há algo de geral e coordenado em toda explicação; a cada momento ela se satisfaz e renova os seus traços pela maneira sintonizada com que reverbera acentos anteriores, isto é, as pernas da sua preparação e do seu advento; 
faz-se logo, reafirmando em blocos as posições, amiga da memória, tornando-a fundamental. É no seguinte sentido que a noção de solidez ou consistência pode encontrar a sua mais perfeita tradução numa ideia-foto: uma consciência perspicaz, especialmente apresentada numa linguagem-luz, repleta de clareiras planas, é a dádiva de toda explicação; a ideia-foto reúne as partes num todo, tornando-as pacificadas numa totalidade original ou numa totalidade de destinação; daí que haja em suas retas a imperiosa vocação de fixar-se num registro monotemático, monográfico. A despeito da atração que pode exercer uma improvisação dissonante, aquele charme ou aquela sensualidade de pensamentos móveis e libertinos, a prudência objetiva da explicação evita aproximá-la de qualquer dinâmica emaranhada que a caracterize como mera experiência; faz-se, assim, como um ato pedagógico-político conservador de certa lógica discursiva, procurando utilizar uma polidez expressiva adequada ou até impecável, para sobrelevar, exatamente, como se o seu discurso não pudesse ter como conteúdo senão a sua própria estabilidade, a relevância expositiva do seu valor. A forma, não a formação, é uma permanência nunca retocada, como economia calculadora; ela reduz tudo a números ou volumes identitários (fios emendados, estátuas protocolares), atividade que maneja o máximo de rendimento do remetente com o mínimo de atenção do destinatário; sente-se nela a ação finalizada, especialmente em suas derivações gramaticais, deduções, induções: o pensamento diz. Enquanto desenho, ela é essencialmente imóvel, não podendo corresponder senão a ideias seguras, revisadas e bem mastigadas; o começo, o meio e o fim existem numa criteriosa fotografagem. Como bem sabe o ocidente, a explicação, por não ser movimento, é ela mesma fotografável ou explicável, podendo ser gravada ou registrada, por exemplo, numa simples partitura (ao se pensar a fotografia pela fotografia, produz-se nova fotografia); aquilo de que se tem explicação se torna um explicável na explicação e um inexplicável na experiência (eis a dificuldade de capturá-la sob o jugo de uma lente puramente cinematográfica); ela é como um desenho talhado em pedra que se oferece ao deleite de incontáveis gerações; e essa vocação para a imobilidade se repete em explicações seguintes, como fotos, despertem-se elas no nível de um capítulo, de um parágrafo ou de uma única palavra. É certo que, num exame, esse pensamento-fotografia é o empreendimento de maior responsabilidade, reivindicando habilidades de fixação e forças de síntese, sempre procurando respeitar, ainda que não perfeitamente, a trindade clarezaobjetividade-concisão; em sentido agudo, como o mar onde pretendem navegar todas as caravelas ou o céu onde pretendem flutuar todos os balões, a ideia-foto, em sua generalidade, 
é universalizável e discutível; todos os seus refúgios ou aposentos precisam ter valores consoantes com esse desejado empenho e desempenho de direta utilidade.

Já a ideia-cinema é a ideia da experiência lógica, com a sua singular leveza aérea e aquífera, julgando destapar ou ferir de fendas todo o abrigo, não sem a expressividade da cólera na qual tamancos de ferro se deixam ouvir sobre assoalhos. O móvel que a ideiacinema pensa, com os ecos de Dionísio e Heráclito, no espírito da vontade, da espontaneidade e da liberdade intelectual, guarda-se nos sepulcros da fixação explicativa: o que pertence à experiência, como ventos mal-humorados, não passa de uma recompensa para o que se diz objetivamente, absolutamente. Nada há de geral e coordenado que possa servir de base para a experiência; ela se satisfaz e ganha ritmo em atos livres, imprevistos e suficientes, como gotículas ambulantes, sem elementos anteriores pelos quais alguém poderia identificar e acompanhar a sua preparação e o seu advento; faz-se logo, alternando em saltos as posições, inimiga da memória, tornando-a supérflua. É no seguinte sentido que a noção de solidez ou consistência é desastrosa na ideia-cinema: uma consciência ingênua, especialmente apresentada numa linguagem-bebê, repleta ou não de ceras aromáticas, é a dádiva de toda experiência; a ideia-cinema em estado bruto não reúne as partes num todo, pois nela o todo é apenas uma parte ao lado das partes; daí que haja em suas curvas a imperiosa vocação de movimentar-se num registro politemático, poligráfico. A despeito das barreiras do senso comum, dos pensamentos solenes e sensatos, certamente muito satisfeitos em sua imobilidade, a imprudência emaranhada da experiência evita aproximá-la de qualquer fixidez objetiva que a caracterize como mera explicação; faz-se, assim, como um ato pedagógicopolítico adulterador de certa lógica discursiva, procurando utilizar diversos ornamentos ou até gratuidades expressivas, para sobrelevar, exatamente, como se o seu discurso não pudesse ter como conteúdo senão a sua própria instabilidade, a irrelevância expositiva do seu valor. A formação, não a forma, é uma impermanência sempre retocada, como inteligência feiticeira; ela obriga os músculos experienciais a uma tensão perpétua (fios soltos, alongadores), atividade que maneja o mínimo de rendimento do remetente com o máximo de atenção do destinatário; não se sente nela a ação finalizada, que é especialmente não sentida em suas derivações gramaticais, deduções, induções: o pensamento paira. Enquanto desenho, ela é essencialmente móvel, não podendo corresponder senão a pensamentos em trabalho de parto, abertos ao devir; ela retém, em seus mil alvéolos, os movimentos descomprimidos, como hastes tremulantes; é no silêncio e no escuro que se combinam essas explosões, perturbando a 
respiração com palpitação. Como bem sabe o oriente, a experiência, por ser movimento, não é fotografável ou explicável; não pode ser gravada ou registrada, por exemplo, numa simples partitura (ao se pensar o vídeo pela fotografia, produz-se no máximo novo vídeo, como segmentação de fotografias já discretas); aquilo de que se tem experiência se torna um experienciável na experiência e um inexperenciável na explicação (eis a dificuldade de capturá-la sob o jugo de uma lente puramente fotográfica); ela é como um desenho feito sobre a superfície da água que se desfaz assim que é esboçado; e essa vocação para a mobilidade se repete em experiências seguintes, como vídeos, despertem-se eles no nível de um capítulo, de um parágrafo ou de uma única palavra. É certo que, num exame, esse pensamento-cinema é o acontecimento de menor responsabilidade, anexato por excelência, flutuando na infindável galeria dos lexemas, alojado em toda parte sem estar preso a lugar algum, apenas encontrando encanto em zombar das censuras fotográficas; em sentido agudo, como as marcas das digitais de um ceramista na argila ou os vestígios de terra nas unhas de um jardineiro, a ideia-cinema, em sua singularidade, não é universalizável nem discutível; ela manifesta um estranho conjunto de espasmos que fazem escoar uma indireta utilidade.

Existe uma dinâmica de funcionamento: tríplice fronteira, jazz, lentidão e excesso. Como tríplice fronteira, entre filosofia, ciência e arte, o exame é uma região impermanente e amorfa, podendo ser mapeado por categorias classificatórias circunstanciais; é que, conforme poderiam detectar certos bichos de fronteira, um ambiente fronteiriço é sempre uma zona volúvel, um pântano com contornos mal definidos, variando, para mais ou para menos, pelo volume sazonal dos três rios que lhe banham; fatalmente se encontram em tal fronteira os sedimentos de distintas regiões, trazidos vez a vez pelos movimentos das águas, mas já sem os sinais incontestáveis de pertencimento que lhe deram fatura, pois agora dissolvidos, desterritorializados; a tríplice fronteira é, assim, não exatamente um existente, como um sítio regular ou definitivo, mas um transexistente, como um sítio de transdisciplinaridade, local de contínuos encontros e deslizamentos, regido por trifurcações - ora mais filosofia, ora mais ciência, ora mais arte, dependendo do momento. É verdade que uma ideia-foto pode se julgar digna somente de um terreno específico, o da ciência, nada mais; mas essa ciência reduzida à explicação só se deve a uma ideia-foto ainda demasiadamente debochada ou ridicularizada por uma ideia-cinema: limitar a explicação no nível científico, com um grau de fingimento que desdenha das mais explícitas flutuações, é a obsessão ou a neurose de toda ideia-cinema, 
com intenção cômica, satírica. A mais justa ideia-foto, ao contrário, encontra a sua morada em qualquer terreno; e a ideia replicada também se faz verdadeira (pode ocorrer, por exemplo, no limite, uma literariedade poderosa no seio da ciência ou da filosofia, poeta à ses heures); essa é, aliás, uma das características emblemáticas da filosofia deleuziana, com a qual se apreende atualmente certa região também impermanente e amorfa para um modo ilimitado de leitura: uma fortuita explicação depende dos véus experienciais que se retorcem sem comedimento. Como jazz, o exame é um sistema politemático ou poligráfico, não sem síncopes e polirritmias, devendo ter nos temas melódicos a sua ideia-foto e nas improvisações a sua ideia-cinema: os temas melódicos, como territórios sempre imóveis, designam um investimento de conteúdo, funcionando como esqueleto, farol ou bússola; as improvisações, como aventuras móveis sobre os territórios imóveis, designam uma execução sem preparação ou ensaio, devendo ser realizada apenas conforme os afetos do momento, no calor da hora, espontânea. Há o improviso que está muitíssimo comprometido com os temas, articulando pop-obviedades, fugindo da arena mais experiencial (fusion ou jazz-rock); há o improviso que vai progressivamente se modificando nas dobraduras dos temas, ainda que deveras inspirado em seus motivos (cool jazz); há o improviso que se afasta da evocação dos temas, ainda que conservando alguns de seus traços elementares (bebop); há o improviso, enfim, que decompõe e esquece totalmente os temas, aqui e agora, como um caracol que, em determinada ocasião, abandona a concha (free jazz). É verdade que tanto pela ideia-foto quanto pela ideia-cinema se pode imaginar um sistema, por assim dizer, não jazzístico; mas esse improvável sistema, destituído da relação entre temas melódicos e improvisações, só se deveria a uma ideia-foto ou a uma ideia-cinema ainda demasiadamente obcecada em si mesma, comportando-se como ilusão: o exclusivismo da explicação, sem movimentos, é a obsessão ou a neurose de toda ideia-foto, assim como o exclusivismo da experiência, sem comunicações, é a obsessão ou a neurose de toda ideia-cinema, com intenção absolutista, totalizante. A mais justa ideia-foto e a mais justa ideia-cinema, ao contrário, encontram os seus sistemas num painel de indispensáveis relações; e a ideia replicada também se faz verdadeira (pode ocorrer, por exemplo, no limite, a dispensabilidade estratégica da concha por parte do caracol); essa é, aliás, uma das características emblemáticas da complicação em Proust et les signes, com a qual se apreende agora certa exigência também sistemática para um modo relacional de leitura: uma fortuita explicação é atravessada ou contornada pela experiência, em notável compromisso tático. Como lentidão e excesso, o exame é uma peça pedagógica-política, 
reunindo exposição e processo, informação e flutuação, comunicação e movimento; essa peça pedagógica-política aponta para uma necessidade de passagem serena, de o leitor conviver, sem desagrado, com a luta miúda das palavras, estancando o gesto da procura apressada, demorando-se com amor em cada passo, como se cada passo tivesse invioláveis direitos próprios; desse modo, ainda que como rebarbas pouco relevantes, os próprios títulos dos capítulos, não permitindo a identificação imediata dos assuntos e, por isso, exigindo que o leitor transite por diversas páginas até encontrar o seu ponto, esboçam o recado pedagógicopolítico de que nunca se deve extrair alguma explicação sem se passar pelas lentas e excessivas malhas da experiência, como semelhantemente exigem as literaturas. É verdade que até mesmo uma ideia-cinema pode acelerar, por exemplo, a floração de uma rosa, como uma imagem de oferenda, operando, rapidamente, no vídeo, com as suas diversas etapas geométricas; mas essa rosa se abrindo sem vagar nem reticências só se deve a uma ideiacinema ainda demasiadamente submissa a uma ideia-foto: suprimir os intermediários, as demoradas agonias de cada momento, é a obsessão ou a neurose de toda ideia-foto, com intenção superexcitada, ejaculação precoce. A mais justa ideia-cinema, ao contrário, encontra o seu ritmo numa lentidão tântrica, quase sempre se traduzindo em excesso (pedagógica e politicamente, pela "flor" de cada segundo); e a ideia replicada também se faz verdadeira (pode ocorrer, por exemplo, no limite, um eventual cinema haicai); essa é, aliás, uma das características emblemáticas da literatura proustiana, com a qual se apreende nos dias de hoje certa exigência também pedagógica-política para um modo desapressado ou paciente de leitura: enquanto germinam as explicações, os véus experienciais se retorcem sem comedimento.

Finalmente, já se pode afirmar que, desdobrando-se ao mesmo tempo sobre e com Deleuze com Proust, a boa forma de qualquer exame deveria ser uma disposição adequada do par explicação-experiência, como instâncias simultâneas, levando-o tanto à exuberância de um já pensado, como foto de ideias, naquela impressão definitiva do que até então se pôde pensar ou se deveu pensar (desenho angélico, apolíneo ou parmenidiano), quanto à exuberância de um contínuo a se pensar ou se pensando, como cinema de ideias, naquela impressão efêmera do que até então poderia ter sido pensado ou deveria ter sido pensado (desenho demoníaco, dionisíaco ou heraclitiano). É possível dizer prontamente que a explicação habita um sótão (zona racional dos projetos intelectualizados), ao passo que a 
experiência habita um porão (zona em que o devaneio trabalha); isso permite lidar com o dilema das escadas pelas quais podem descer anjos e subir demônios, encontrando-se todos num térreo: eis aí, talvez, o cômodo híbrido da ideia foto-cinema enquanto desenho de pensamento. Noutra imagem de origem bachelardiana, já se insinuou que a ideia-foto é uma concha e a ideia-cinema, um caracol: a casa da explicação (prisão de pedra, apartamento rígido) aparece na exata proporção em que cresce o corpo experiencial que a habita (molusco inquieto, hóspede em movimento). Essa é então a inevitabilidade da relação entre explicação e experiência: o caracol solitário carrega o tempo todo a casinha consigo, como um leito seguro; até certo ponto, aliás, ele está sempre em casa, independentemente dos terríveis movimentos que faça. Foto-cinema é, assim, de uma só vez, exposição e processo, informação e flutuação, comunicação e movimento, associando polidez e travessura. Na medida em que a explicação, ocidentalmente, faz a anatomia terminante de uma capela ou de um templo, a experiência, orientalmente, faz a anatomia provisória de uma caverna ou de um eremitério; por exemplo, na explicação laboratorial se fala de "lógica" como um encadeamento demonstrativo, um sistema racional em equilíbrio ( $\mathrm{A}<\mathrm{B}$ e $\mathrm{B}>\mathrm{C}=\mathrm{B}>\mathrm{A}$ e $\mathrm{C}$ ), mas na experiência lógica se fala de "lógica" como um trânsito no indemonstrável, uma relação com o impensável, podendo ser o pensamento tanto mais lógico quanto mais escapando de toda a demonstrabilidade (lógica alógica - e não "ilógica"). No desenho de pensamento, as duas instâncias compartilham o mesmo ambiente, o mesmo térreo, não impedindo o surgimento de certos desarmônicos, como se vê abaixo, em dois tipos comuns de problemas. Por um lado, a repercussão fotográfica, envolvida na exuberância de um já pensado, com indubitáveis pretensões de fixação, nas camadas dos argumentos que lhe dizem respeito ou nas intervenções criadoras que lhe dão ossos, pode abafar a repercussão cinematográfica da experiência, dando-a como um pensamento totalmente configurado, que apenas finge pairar (fusion ou jazz-rock). É que, especialmente em situação de exame, a ideia-foto, como recompensa para o que não se diz objetivamente, absolutamente, não convive muito bem com a ideia-cinema, tentando consumi-la, torná-la inoperante, inexistente, um fóssil (como ocorre nos GIFs - Graphics Interchange Format - de Kevin Burg e Jamie Beck, nos quais a ideia-cinema permanece adestrada pela ideia-foto); seus fios sedosos e insinuantes, que parecem leves, logo se tencionam; as roupas que a urdem se mostram como uma apertada camisa-de-força para a ideia-cinema (tudo isso ainda aqui, diga-se, neste exato momento, nas presentes linhas). Por exemplo, a própria comodidade, essencialmente fotográfica, que torna possível definir e 
anunciar a ideia-foto como a ideia da explicação e a ideia-cinema como a ideia da experiência é, em si mesma, nas entranhas do seu ato explicativo, a eliminação de um verdadeiro movimento. Por outro lado, a repercussão cinematográfica, envolvida na exuberância de um contínuo a se pensar ou se pensando, com indubitáveis malandragens ou pirotecnias, no fio tênue da frase ou no instante vago da palavra, pode abafar a repercussão fotográfica da explicação, dando-a como um pensamento totalmente desconfigurado, que apenas finge não pairar (free jazz). É que, em qualquer situação, a ideia-cinema, como recompensa para o que se diz objetivamente, absolutamente, ainda que convivendo muito bem com a ideia-foto, precisando dela exatamente para se fazer e viver, não permite censura de seus movimentos exploratórios ou de seus desatinos (tudo isso ainda aqui, diga-se, neste exato momento, nas presentes linhas). Por exemplo, a própria comodidade, essencialmente cinematográfica, de nunca fixar definitivamente um pensamento, enredando-o em diversas direções, como variação de redes entrecruzadas, $a$ e $a^{1}, b$ e $b^{1}, c$ e $c^{1}$, é, em si mesma, nas entranhas do seu ato experiencial, ainda que convocando o hemisfério da explicação, aquele que se caracteriza pelas superfícies de contato, pela fruição de determinados problemas e pela vibração de linhas entre um $a$ e um $b$, uma verdadeira traição à ideia-foto. Sem dúvida, há uma irremovível tensão entre as duas ideias, o que torna o próprio "par" indigesto à traduction; buscar precisamente os seus atributos ou esquematizar as suas feições é tarefa para um leitor muito severo, severíssimo, obcecado, talvez, em alguma prova físico-mental que possa conferir uma aparência épica às coisas; mesmo ele corre o risco de encontrar apenas um jogo verborrágico ou uma vaidosa irresponsabilidade se não lhe vier a hipótese de que é necessário pensar alguma coisa não ortodoxa para tal foto-cinematografia do pensamento. Como no jazz, que tem nos temas melódicos a sua ideia-foto e nas improvisações a sua ideia-cinema, é preciso suspender toda a percepção que se oriente somente pela simetria do rock and roll, aquela que se ajusta à desenvoltura, por vezes muito agradável e convincente, aliás, de apenas dois ou três acordes. Para o primeiro tipo de problema, isto é, quando a explicação abafa a experiência, poder-se-á dizer então que mesmo o fóssil de um movimento não é um movimento morto, mas o estágio perspectivo de um adormecido em relação a todo um conjunto de movimentos emergenciais que ele próprio ainda (e sempre) desperta; por conta do universo da experiência, há um incrível dom de revivências alternadas, como fazem as paráfrases jazzísticas, modificando a seu modo as canções standards: o experiencial não termina o seu trabalho quando uma (ou duas) das paredes ficou firme; ele choca, aquece 
novos filhotes, aos montes, sem previsibilidade. Para o segundo tipo de problema, isto é, quando a experiência abafa a explicação, poder-se-á dizer então que, a despeito da inevitável convivência entre as duas instâncias, mesmo a concha está vulnerável ao drama de ser em algum momento abandonada ou traída pelo caracol, como ocorre, por exemplo, quando uma improvisação free jazzística, numa deliciosa e espontânea assimetria, transcende em completo o tema melódico que a agasalhou; desta forma, a relação do caracol (experiência) com a concha (explicação) é como a de uma mão que providencialmente se associa a um olho, tendo-o por um breve momento como esqueleto, farol ou bússola, mas imediatamente já o pondo, por conta de seus preciosos malabarismos, na emergência de um movimento infinitamente dinamizado: os alongadores experienciais, na contramão de qualquer ortodoxia teológica, desdenham de toda estátua protocolar fomentada por um ideal de síntese e conclusão, sugerindo sempre que não há exame sem fios soltos, paredes demolíveis, pedras que se tornam água. 


\section{BIBLIOGRAFIA}

ALLIEZ, Éric. A assinatura do mundo: o que é a filosofia de Deleuze e Guattari?. Trad. Maria Helena Rouanet e Bluma Villar. Rio de Janeiro: Ed. 34, 1994. . Deleuze filosofia virtual. Trad. Heloisa B. S. Rocha. São Paulo: Ed. 34, 1996.

ALMEIDA, Júlia. Estudos deleuzeanos da linguagem. Campinas: Ed. Unicamp, 2003.

BARTHES, Roland. "Proust e os nomes". In: O grau zero da escrita: seguido de novos ensaios críticos. Trad. Mário Laranjeira. São Paulo: Martins Fontes, 2004.

BATAILLE, Georges. "Marcel Proust et la mère profanée". In: La littérature et le mal. Paris: Gallimard, 1957.

BECKETT, Samuel. Proust. Trad. Arthur Nestrovski. São Paulo: Cosac \& Naify, 2003.

BENJAMIN, Walter. "A imagem de Proust". In: . Magia e técnica, arte e política: ensaios sobre literatura e história da cultura. Trad. Sergio Paulo Rouanet. São Paulo: Brasiliense, 1994.

BOGUE, Ronald. Deleuze and Guattari. New York: Routledge, 1989.

BRUN, Bernard. Marcel Proust. Paris: Le Cavalier Bleu, 2007.

BUTOR, Michel. "Les oeuvres d'art imaginaires chez Proust". In: Répertoire II. Paris: Minuit, 1964.

CARDOSO JR, Hélio Rebello. "Deleuze, empirismo e pragmatismo: linhas de força do encontro com a teoria peirceana dos signos", in Revista Síntese, Belo Horizonte, v. 33, n. 106, p. 199-211, 2006.

CHAUDIER, Stéphane. "Proust aux éclats". In: GELAS, Bruno e MICOLET, Hervé (orgs.). Deleuze et les écrivains: littérature et philosophie. Nantes: Cécile Defaut, 2007.

CHKLOVSKI, Vitor. “A arte como procedimento". In: EIKHENBAUM, Boris et al. Teoria da literatura: formalistas russos. Trad. Boris Schnaiderman. Porto Alegre: Globo, 1976. DELEUZE, Gilles. Proust et les signes. Paris: PUF, 1998.

. Proust e os signos. Trad. Antonio Carlos Piquet e Roberto Machado. Rio de Janeiro: Forense Universitária, 2010. . Nietzsche e a filosofia. Trad. Edmundo Fernandes Dias e Ruth Joffily Dias. Rio de Janeiro: Ed. Rio, 1976. 
. Nietzsche. Trad. Alberto Campos. Lisboa: Edições 70, 2009.

. Bergsonismo. Trad. Luiz Benedicto Lacerda Orlandi. São Paulo: Ed. 34, 1999.

. Sacher-Masoch: o frio e o cruel. Trad. Jorge Bastos. Rio de Janeiro: Jorge Zahar, 2009.

. Diferença e repetição. Trad. Luiz Benedicto Lacerda Orlandi e Roberto Machado.

Rio de Janeiro: Graal, 1988.

. A imagem-tempo. Trad. Eloisa de Araujo Ribeiro. São Paulo: Brasiliense, 2007.

. Conversações (1972-1990). Trad. Peter Pál Pelbart. São Paulo: Ed. 34, 1992.

. Crítica e clínica. Trad. Peter Pál Pelbart. São Paulo: Ed. 34, 1997.

. A ilha deserta e outros textos. Trad. Luiz Benedicto Lacerda Orlandi et al. São Paulo:

Iluminuras, 2006.

. Deux régimes de fous. Paris: Minuit, 2003.

DELEUZE, Gilles e GUATTARI, Félix. $O$ anti-Édipo. Trad. Luiz Benedicto Lacerda Orlandi.

São Paulo: Ed. 34, 2010.

. Kafka: para uma literatura menor. Trad. Rafael Godinho. Lisboa: Assírio \& Alvim, 2003.

. Mil platôs: capitalismo e esquizofrenia, vol. 1. Trad. Aurélio Guerra Neto e Celia

Pinto Costa. São Paulo: Ed. 34, 1995.

. O que é a filosofia?. Trad. Bento Prado Jr. e Alberto Alonso Muñoz. Rio de Janeiro:

Ed. 34, 1992.

DELEUZE, Gilles e PARNET, Claire. Diálogos. Trad. José Gabriel Cunha. Lisboa: Relógio D’água, 2004.

DESCOMBES, Vincent. Proust, philosophie du roman. Paris: Minuit, 1987.

DIAS, Sousa. Lógica do acontecimento: Deleuze e a filosofia. Porto: Afrontamento, 1995. ."Partir, evadir-se, traçar uma linha`: Deleuze e a literatura”, in Educação, Porto Alegre, PUC-RS, n. 2 (62), p. 277-285, maio/agosto, 2007.

DOSSE, François. Gilles Deleuze e Félix Guattari: biografia cruzada. Trad. Fatima Murad. Porto Alegre: Artmed, 2010.

FERRARIS, Maurizio e DE AGOSTINI, Daniela. "Proust, Deleuze et la répétition: notes sur les niveaux narratifs d'A la recherche du temps perdu", in Littérature, n. 32, décembre, 1978. 
FOUCAULT, Michel. "Theatrum philosophicum". In: - Arqueologia das ciências e história dos sistemas de pensamento (Ditos e escritos - vol. 2). Trad. Elisa Monteiro. Rio de Janeiro: Forense Universitária, 2008.

GENETTE, Gérard. "Proust palimpseste". In: . Figures I. Paris: Éditions du Seuil, 1966.

GODINO, Ana. Linhas do estilo: estética e ontologia em Gilles Deleuze. Lisboa: Relógio D’água, 2007.

GUATTARI, Félix. "Fundamentos éticos-políticos da Interdisciplinaridade", in Tempo Brasileiro, n. 108, p. 19-29, janeiro/março, 1992.

GUATTARI, Félix. “A transversalidade”. In: . Psicanálise e transversalidade: ensaios de análise institucional. Trad. Adail Ubirajara Sobral e Maria Stela Gonçalves. Aparecida: Ideias \& Letras, 2004.

HENRY, Anne. Proust romancier, le tombeau égyptien. Paris: Flammarion, 1983.

KAFKA, Franz. O veredicto. Na colônia penal. Trad. Modesto Carone. São Paulo: Companhia das Letras, 1998.

KANT, Immanuel. Manual dos cursos de Lógica Geral. Trad. Fausto Castilho. Campinas, Uberlândia: Ed. Unicamp, Edufu, 2003.

KOSSOVITCH, Leon. “Gilles Deleuze, Francis Bacon”, in Revista USP, São Paulo, n. 57, p. 160-168, março/maio, 2003.

LAPOUJADE, David. Deleuze, os movimentos aberrantes. Trad. Laymert Garcia dos Santos. São Paulo: n-1 edições, 2015.

LAVAGETTO, Mario. Chambre 43: un lapsus de Marcel Proust. Paris: Belin, 1996.

MACHADO, Roberto. Deleuze, a arte e a filosofia. Rio de Janeiro: Jorge Zahar, 2010.

MAURIAC, Nathalie. Proust inachevé. Paris: Champion, 2005.

MAYER, Arno. A força da tradição: a persistência do Antigo Regime. Trad. Denise Bottmann. São Paulo: Companhia das Letras, 1987.

MICOLET, Hervé. “Introduction”. In: GELAS, Bruno e MICOLET, Hervé (orgs.). Deleuze et les écrivains: littérature et philosophie. Nantes: Cécile Defaut, 2007.

MILLER, Milton. Psychanalyse de Proust. Paris: Fayard, 1977.

NABAIS, Catarina Pombo. "Introduction - quatre, trois, deux". In: Gilles Deleuze: philosophie et literature. Paris: L'Harmattan, 2013.

NANCY, Jean-Luc. "Dobra deleuzeana do pensamento”. In: ALLIEZ, Éric (org.). Gilles Deleuze: uma vida filosófica. Trad. Ana Lúcia de Oliveira. São Paulo: Ed. 34, 2000. 
NIETZSCHE, Friedrich. Além do bem e do mal. Trad. Paulo César de Souza. São Paulo: Companhia das Letras, 2005a. . Assim falou Zaratustra. Trad. Mário da Silva. Rio de Janeiro: Civilização Brasileira, $2005 b$.

ORLANDI, Luiz Benedicto Lacerda. "Signos proustianos numa filosofia da diferença". In: OLIVEIRA, Sérgio Lopes, PARLATO, Érika Maria e RABELLO, Silvana (orgs.). $O$ falar da linguagem. São Paulo: Lovise, 1996.

“O filósofo e seus ovos”, in Artefilosofia, Ouro Preto, UFOP, n. 9, p. 126-140, outubro, 2010.

PELBART, Peter Pál. A vertigem por um fio: políticas da subjetividade contemporânea. São Paulo: Iluminuras, 2000a.

“O tempo não-reconciliado”. In: ALLIEZ, Éric (org.). Gilles Deleuze: uma vida filosófica. São Paulo: Ed. 34, 2000b.

PIAGET, Jean. "L"epistémologie des relations interdisciplinaires". In: OCDE, L'interdisciplinarité: problèmes d'enseignement et de recherche dans les universités. Paris: OCDE, 1972.

POULET, Georges. O espaço proustiano. Trad. Ana Luiza B. Martins Costa. Rio de Janeiro: Imago, 1992.

PROUST, Marcel. No caminho de Swann. Trad. Fernando Py. Rio de Janeiro: Ediouro, 2002. . À sombra das moças em flor. Trad. Fernando Py. Rio de Janeiro: Ediouro, 2002. . O caminho de Guermantes. Trad. Fernando Py. Rio de Janeiro: Ediouro, 2002. . Sodoma e Gomorra. Trad. Fernando Py. Rio de Janeiro: Ediouro, 2002. . A prisioneira. Trad. Fernando Py. Rio de Janeiro: Ediouro, 2002. . A fugitiva. Trad. Fernando Py. Rio de Janeiro: Ediouro, 2002. . O tempo recuperado. Trad. Fernando Py. Rio de Janeiro: Ediouro, 2002. . Contre Sainte-Beuve: notas sobre crítica e literatura. Trad. Haroldo Ramanzini. São Paulo: Iluminuras, 1988.

. Correspondance: texte établi, présenté et annoté par Philip Kolb, Tome XIII, lettre 43, pour Jacques Rivière (6 février 1914), Paris: Plon, 1985.

RICOEUR, Paul. "À la recherche du temps perdu: o tempo atravessado". In: . Teтpo e narrativa (v. 2). Trad. Márcia Valéria Martinez de Aguiar. São Paulo: Martins Fontes, 2010. 
. "O reconhecimento e a prova do desconhecível". In: - Percurso do reconhecimento. Trad. Nicolás Nyimi Campanário. São Paulo: Edições Loyola, 2006. RIMBAUD, Arthur. Correspondance (nouvelle edition augmentée). Paris: Arvensa, 2014. ROLNIK, Suely. "Ninguém é deleuziano" (entrevista a Liro Neto e Silvio Gadelha), in $O$ povo, Caderno Sábado: 6, Fortaleza, 18 novembro 1995.

SAUVAGNARGUES, Anne. Deleuze et l'art. Paris: PUF, 2006.

SHATTUCK, Roger. Proust's binoculars: a study of memory, time and recognition. Princeton: Princeton University Press, 1983.

SPITZER, Leo. "Le style de Marcel Proust”. In:__. Études de style. Paris: Gallimard. 1970. TADIÉ, Jean-Yves. Proust et le roman. Paris: Gallimard, 1971.

VILLANI, Arnaud. La guêpe et l'orchidée: essai sur Gilles Deleuze. Paris: Belin, 1999. ."Deleuze e a anomalia metafísica". In: ALLIEZ, Éric (org.). Gilles Deleuze: uma vida filosófica. Trad. Ana Lúcia de Oliveira. São Paulo: Ed. 34, 2000.

WARNING, Rainer e MILLY, Jean. Marcel Proust: écrire sans fin. Paris: CNRS, 1996.

ZOURABICHVILI, François. Deleuze: une philosophie de l'événement. Paris: PUF, 1996. . "Deleuze e a questão da literalidade", in Educação \& Sociedade, Campinas, v. 26, n. 93, p. 1309-1321, set-dez, 2005. . O vocabulário de Deleuze. Trad. André Telles. Rio de Janeiro: Relume Dumará, 2009.

ZIMA, Pierre. L'ambivalence romanesque: Proust, Kafka, Musil. Paris: L’Harmattan, 2002. 